\title{
\#USGS
}

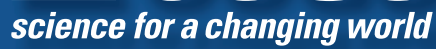

Prepared in cooperation with the City of Salem, Oregon

\section{Major Turbidity Events in the North Santiam River Basin, Oregon, Water Years 1999-2004}

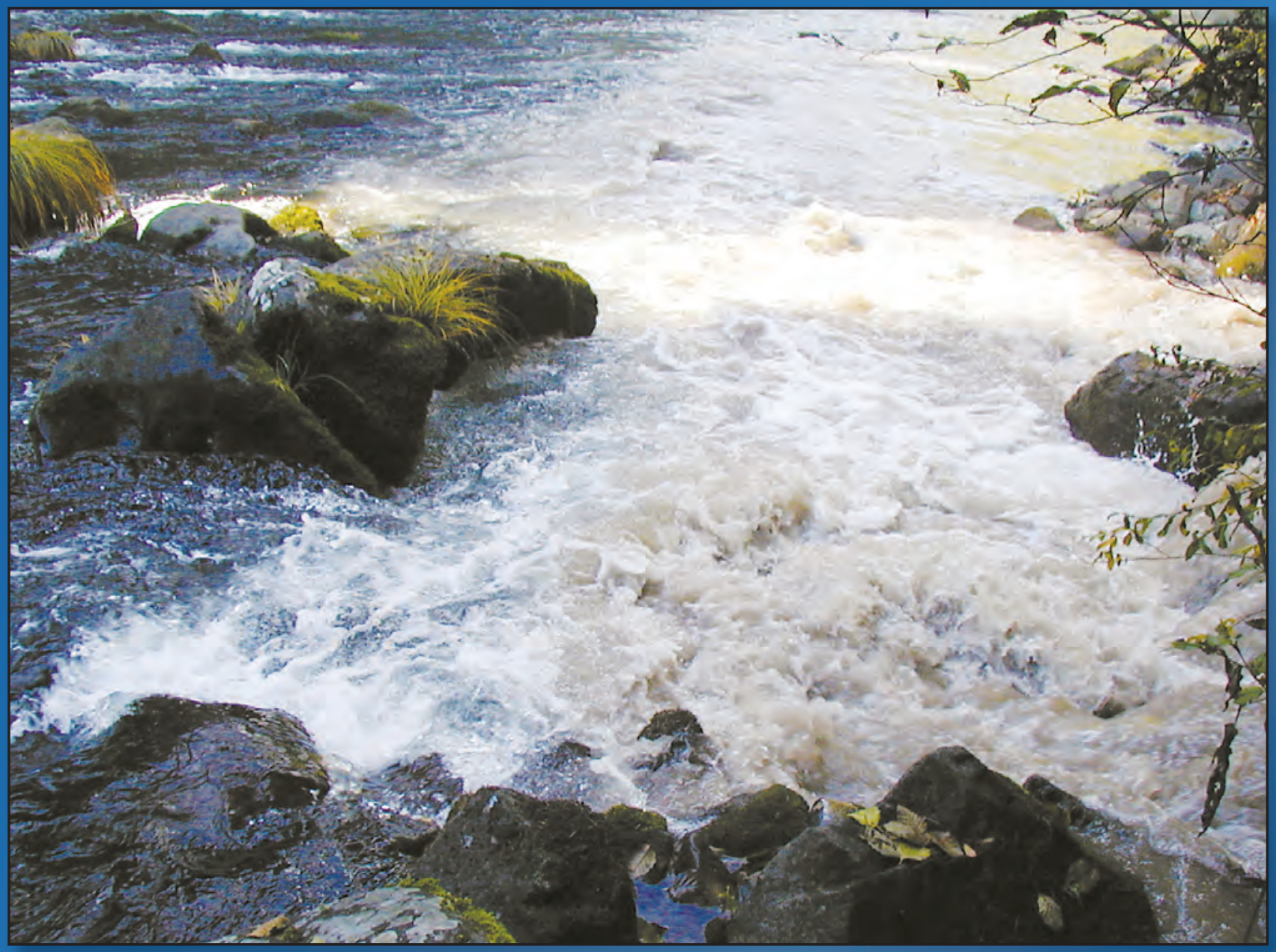

Scientific Investigations Report 2007-5178

U.S. Department of the Interior

U.S. Geological Survey 
Front Cover: Photograph showing turbid water flowing from Pamelia Creek into the North Santiam River, October 2003. Photograph by U.S. Geological Survey, taken in 2003.

Back Cover: Photograph showing Divide Creek earthflow in the Blowout Creek subbasin of the North Santiam River basin, Oregon. Photograph by U.S. Geological Survey, taken in 2004.

Back Cover Inset: Photograph showing debris flow scar resulting from Ivy Creek landslide in the Blowout Creek subbasin of the North Santiam River basin, Oregon. Photograph by U.S. Geological Survey, taken in 2001. 


\section{Major Turbidity Events in the North Santiam River Basin, Oregon, Water Years 1999-2004}

By Steven Sobieszczyk, Mark A. Uhrich, and Heather M. Bragg

Prepared in cooperation with the City of Salem, Oregon

Scientific Investigations Report 2007-5178 


\title{
U.S. Department of the Interior DIRK KEMPTHORNE, Secretary
}

\author{
U.S. Geological Survey \\ Mark D. Myers, Director
}

\section{U.S. Geological Survey, Reston, Virginia: 2007}

For product and ordering information:

World Wide Web: http://www.usgs.gov/pubprod

Telephone: 1-888-ASK-USGS

For more information on the USGS--the Federal source for science about the Earth, its natural and living resources, natural hazards, and the environment:

World Wide Web: http://www.usgs.gov

Telephone: 1-888-ASK-USGS

Any use of trade, product, or firm names is for descriptive purposes only and does not imply endorsement by the U.S. Government.

Although this report is in the public domain, permission must be secured from the individual copyright owners to reproduce any copyrighted materials contained within this report.

Suggested citation:

Sobieszczyk, S., Uhrich, M.A., and Bragg, H.M., 2007, Major turbidity events in the North Santiam River basin, Oregon, water years 1999-2004: U.S. Geological Survey Scientific Investigations Report 2007-5178, 50 p. 


\section{Contents}

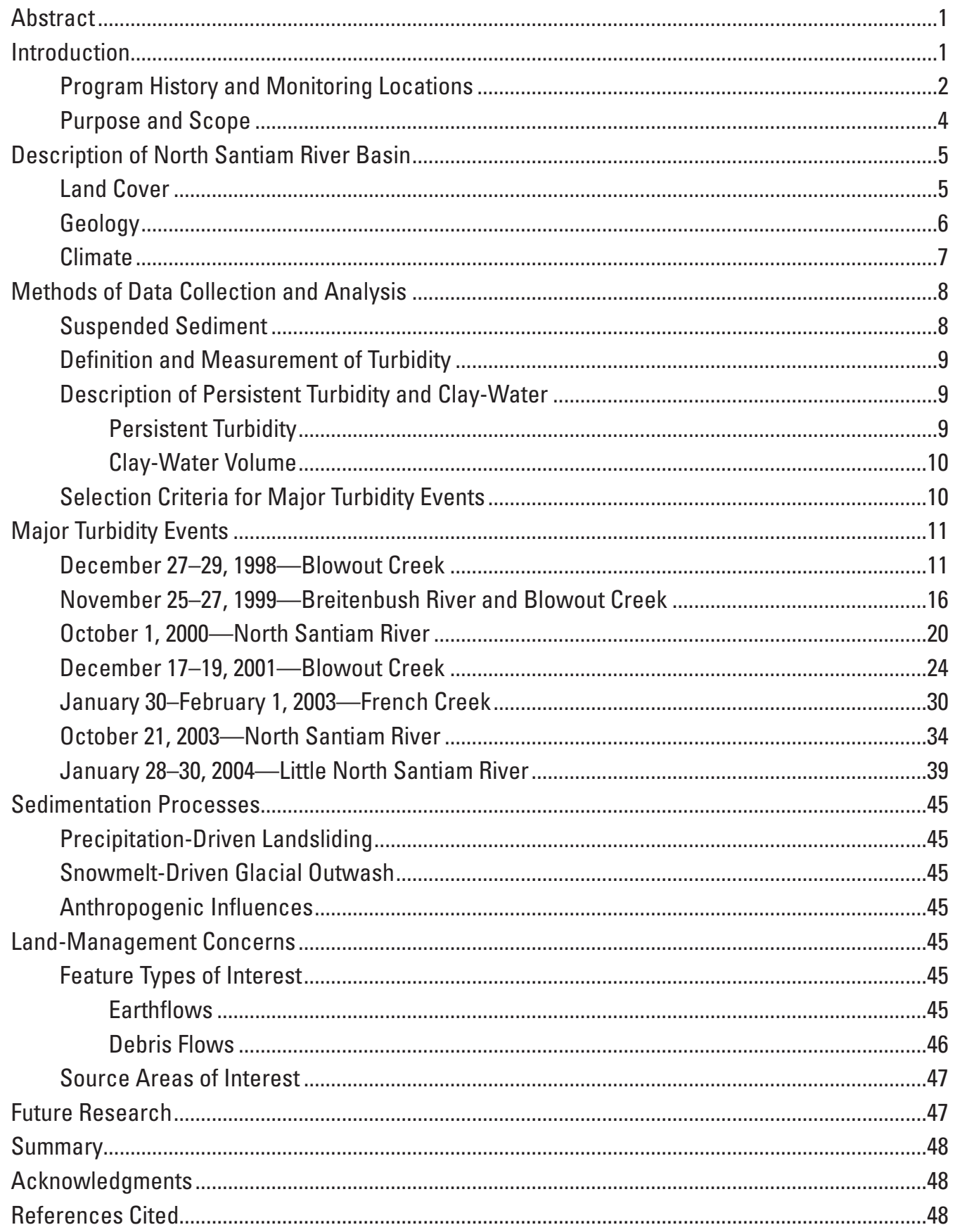




\section{Figures}

Figure 1. Map showing location of study area and streamflow and water-quality monitoring stations in the North Santiam River basin, Oregon

Figure 2. Graphs showing turbidity records for major turbidity events in five unregulated streams in the North Santiam River basin, Oregon, water years 1999-2004

Figure 3. Map showing land management in the North Santiam River basin, Oregon ....... 5

Figure 4. Map showing land cover in the North Santiam River basin, Oregon ............. 6

Figure 5. Map showing surficial geology of the North Santiam River basin, Oregon $\ldots \ldots \ldots$

Figure 6. Graph showing instream turbidity thresholds for persistent turbidity and clay-water volume estimates at five unregulated streams in the North Santiam River basin, Oregon, water years 1999-2006

Figure 7. Graph showing turbidity and discharge at three upper basin monitoring stations for the December 27-29, 1998, major turbidity event in North Santiam River basin, Oregon

Figure 8. Map showing location of Blowout Creek and Divide Creek earthflows in the Blowout Creek subbasin of the North Santiam River basin, Oregon

Figure 9. Photograph showing Blowout Creek earthflow in the Blowout Creek subbasin of the North Santiam River basin, Oregon

Figure 10. Photograph showing Divide Creek earthflow in the Blowout Creek subbasin of the North Santiam River basin, Oregon

Figure 11. Graph showing turbidity and discharge at three upper basin monitoring stations for the November 25-27, 1999, major turbidity event in the North Santiam River basin, Oregon .....

Figure 12. Map showing location of the East Humbug Creek landslide in the Breitenbush River subbasin of the North Santiam River basin, Oregon

Figure 13. Photograph showing East Humbug Creek landslide in the Breitenbush River subbasin of the North Santiam River basin, Oregon

Figure 14. Graph showing turbidity and discharge at three upper basin monitoring stations for the October 1, 2000, major turbidity event in the North Santiam River basin, Oregon

Figure 15. Photograph showing turbid water flowing from Pamelia Creek into the North Santiam River, Oregon, in October 2000

Figure 16. Map showing location of Milk Creek Glacier in the upper North Santiam basin, Oregon

Figure 17. Graph showing turbidity and discharge at four upper basin monitoring stations for the December 17-19, 2001, major turbidity event in the North Santiam River basin, Oregon

Figure 18. Map showing location of Ivy Creek landslide in the Blowout Creek subbasin of the North Santiam River basin, Oregon ...

Figure 19. Photograph showing Ivy Creek landslide and subsequent road failure of Forest Road 1012 in the Blowout Creek subbasin of the North Santiam River basin, Oregon 


\section{Figures-Continued}

Figure 20. Photograph showing debris flow scar resulting from Ivy Creek landslide in the Blowout Creek subbasin of the North Santiam River basin, Oregon

Figure 21. Photograph showing enlarged scarp from the Ivy Creek landslide along decommissioned Forest Road 1012 in the Blowout Creek subbasin of the North Santiam River basin, Oregon. (Photograph by U.S. Geological Survey, taken in 2006).

Figure 22. Graph showing turbidity and discharge at four upper basin monitoring stations for the January 30-February 1, 2003, major turbidity event in the North Santiam River basin, Oregon

Figure 23. Map showing location of French Creek debris flow in the French Creek subbasin of the North Santiam River basin, Oregon

Figure 24. Photograph showing debris flow in French Creek subbasin of the North Santiam River basin

Figure 25. Graph showing turbidity and discharge at four upper basin monitoring stations for the October 21, 2003, major turbidity event in the upper North Santiam River basin, Oregon

Figure 26. Photograph showing automatic pumping samples collected during the October 21, 2003, major turbidity event in the upper North Santiam River basin, Oregon

Figure 27. Photograph showing turbid water flowing from Pamelia Creek into the North Santiam River, Oregon, in October 2003.

Figure 28. Photograph showing glaciofluvial and moraine deposits in the upper North Santiam River basin, Oregon

Figure 29. Photograph showing landslide in Mt. Jefferson Wilderness Area in the upper North Santiam River basin, Oregon

Figure 30. Graph showing turbidity and discharge at five unregulated stream monitoring stations for the January 28-30, 2004, major turbidity event in the North

Santiam River basin, Oregon

Figure 31. Photograph showing turbid water flowing from Evans Creek into the Little North Santiam River, Oregon, in January 2004

Figure 32. Map showing location of the Evans Creek landslide in the Little North Santiam River subbasin of the North Santiam River basin, Oregon

Figure 33. Photograph showing Evans Creek landslide in the Little North Santiam River subbasin of the North Santiam River basin, Oregon

Figure 34. Graph showing turbidity values at three locations within the Little North Santiam River subbasin, Oregon, December 2005

Figure 35. Photograph showing culvert failure on Forest Road 10 in the Blowout Creek subbasin of the North Santiam River basin, Oregon 


\section{Tables}

Table 1. Streamflow-gaging and water-quality monitoring stations used to collect water-quality samples in the North Santiam River basin, Oregon

Table 2. Regression models used to estimate suspended-sediment concentration from instream turbidity measurements on five unregulated streams in the North Santiam River basin, Oregon, waters years 1999-2006

Table 3. Regression models used to estimate persistent turbidity from initial turbidity on five unregulated streams in the North Santiam River basin, Oregon, water years 1999-2006

Table 4. Suspended-sediment load and yield, and clay-water volume and yield for the December 27-29, 1998, major turbidity event in the North Santiam River basin, Oregon

Table 5. Suspended-sediment load and yield, and clay-water volume and yield for the November 25-27, 1999, major turbidity event in the North Santiam River basin, Oregon

Table 6. Suspended-sediment load and yield, and clay-water volume and yield for the October 1, 2000, major turbidity event in the North Santiam River basin, Oregon ... 21

Table 7. Suspended-sediment load and yield, and clay-water volume and yield for the December 17-19, 2001, major turbidity event in the North Santiam River basin, Oregon

Table 8. Suspended-sediment load and yield, and clay-water volume and yield for the January 30-February 1, 2003, major turbidity event in the North Santiam River basin, Oregon

Table 9. Suspended-sediment load and yield, and clay-water volume and yield for the October 21, 2003, major turbidity event in the North Santiam River basin, Oregon

Table 10. Suspended-sediment load and yield, and clay-water volume and yield for the January 28-30, 2004, major turbidity event in the North Santiam River basin, Oregon

Table 11. Percentage of annual total clay-water discharge by subbasin in the North Santiam River basin, Oregon 


\section{Conversion Factors and Datums}

Conversion Factors

\begin{tabular}{lcl}
\hline Multiply & By & To obtain \\
\hline acre & 0.004047 & square kilometer $\left(\mathrm{km}^{2}\right)$ \\
cubic foot per second $\left(\mathrm{ft}^{3} / \mathrm{s}\right)$ & 0.02832 & cubic meter per second $\left(\mathrm{m}^{3} / \mathrm{s}\right)$ \\
cubic yard $\left(\mathrm{yd}^{3}\right)$ & 0.7646 & cubic meter $\left(\mathrm{m}^{3}\right)$ \\
foot $(\mathrm{ft})$ & 0.3048 & meter $(\mathrm{m})$ \\
inch (in.) & 2.54 & centimeter $(\mathrm{cm})$ \\
mile (mi) & 1.609 & kilometer $(\mathrm{km})$ \\
million gallons $(\mathrm{Mgal})$ & 3,785 & cubic meter $\left(\mathrm{m}^{3}\right)$ \\
square mile $\left(\mathrm{mi}{ }^{2}\right)$ & 2.590 & square kilometer $\left(\mathrm{km}^{2}\right)$ \\
ton per minute (ton $/ \mathrm{min})$ & 0.9072 & metric ton per minute \\
ton per square mile (ton $\left./ \mathrm{mi}^{2}\right)$ & 0.3503 & megagram per square \\
& & kilometer $\left(\mathrm{Mg} / \mathrm{km}^{2}\right)$ \\
\hline
\end{tabular}

Temperature in degrees Fahrenheit $\left({ }^{\circ} \mathrm{F}\right)$ may be converted to degrees Celsius $\left({ }^{\circ} \mathrm{C}\right)$ as follows:

${ }^{\circ} \mathrm{C}=\left({ }^{\circ} \mathrm{F}-32\right) / 1.8$.

Suspended-sediment concentration (SSC) is reported in milligrams per liter (mg/L).

Datums

Vertical coordinate information is referenced to the National Geodetic Vertical Datum of 1929 (NGVD 1929). Altitude, as used in this report, refers to distance above the vertical datum. Horizontal coordinate information is referenced to the North American Datum of 1927 (NAD 27). 
This page left intentionally blank 


\title{
Major Turbidity Events in the North Santiam River Basin, Oregon, Water Years 1999-2004
}

\author{
By Steven Sobieszczyk, Mark A. Uhrich, and Heather M. Bragg
}

\section{Abstract}

Multiple high-turbidity events with values greater than 250 Formazin Nephelometric Units occurred in streams of the North Santiam River basin during water years 1999-2004. By using a combination of field reconnaissance, aerial photography, and geographic information systems, eight of these high-turbidity events were investigated and linked to at least one likely source area and became known as "major turbidity events." Sediment source type and location, the amount of material transported, and the results of any followup investigation of the source area were recorded for each event.

Significant findings from this study include:

- Although heavy precipitation caused basinwide erosion that increased turbidity in streams, a major turbidity event often required at least one landslide or similar type of contributing source to introduce enough sediment to raise the turbidity value to greater than 250 Formazin Nephelometric Units.

- Different processes drove sediment loading at different times. In general, precipitation eroded sediment from source areas or induced landslides. However, in two cases, warm temperatures caused rapid snowmelt, which supplied the water necessary to erode unconsolidated glacial soils or other sediment material and increase turbidity.

- Some source areas, such as existing earthflows, repeatedly supplied a large volume of sediment to streams, whereas other sources, such as landslides or debris flows, were unpredictable and sporadically supplied large volumes of sediment to streams.

- Major turbidity events were well distributed throughout the North Santiam River basin; discrete events were observed for each of the five monitoring stations on unregulated streams.

- Suspended-sediment loads and clay-water (persistently turbid water) volume estimates were event-specific and varied greatly between major turbidity events, even though, in some cases, the source area was the same; however, high yields generally were observed for events in the Blowout Creek, Breitenbush River, and Little North Santiam River subbasins.

- Suspended-sediment loads for each 3-day precipitationdriven major turbidity event supplied greater than 36 percent of the annual load, and snowmelt-driven events supplied greater than 27 percent of the annual load in a single day.

- Clay-water yields for event periods generally were highest in the Little North Santiam River subbasin. In addition, average annual percentage of clay-water volume during the period of record was highest in the Little North Santiam River. The second highest average was in Blowout Creek.

\section{Introduction}

The lower mainstem North Santiam River, downstream of Detroit Lake and Big Cliff Reservoir, is the primary source of drinking water for residents of the City of Salem, Oregon, and the surrounding communities - an area with a combined population of more than 177,000 . Because river water is used for consumption, many local agencies monitor any changes to water quality in the basin. For example, turbidity, the cloudiness of water caused by suspended particles, became a major concern for the City of Salem water-treatment facility in February 1996, when heavy rainfall and melting snow flooded streams to greater than 50-year levels (Cooper, 2005). The high flows and accumulated rainfall saturated the landscape, mobilized landslides, and accelerated erosion throughout the North Santiam River basin (U.S. General Accounting Office, 1998). The resulting high turbidity in the North Santiam River forced the water-treatment facility to close its intakes for 8 days (Uhrich and Bragg, 2003). Much of the colloidal material remained suspended for months after the event, which necessitated costly pretreatment to meet drinking-water standards. At the time, guidelines for drinking water stated that treated water must not exceed 1 NTU (Nephelometric Turbidity Unit, see section, "Definition and Measurement of Turbidity,") and not exceed 0.3 NTU in 95 percent of daily samples in any month (Hulse and others, 2002; U.S. Environmental Protection Agency, 2002). 
Because of the geologic characteristics of the North Santiam River basin (see section, "Geology"), turbiditycausing sediments are easily mobilized by storm runoff. If the eroded sediments are clay-rich, the particles remain suspended for long periods, resulting in persistent turbidity (see section, "Description of Persistent Turbidity and Clay-Water"). The City of Salem water-treatment facility can directly treat water that has a low turbidity value (less than $10 \mathrm{NTU}$ ); more turbid water (as high as 50 NTU) can be treated by several alternative pretreatment and distribution systems (Tim Sherman, City of Salem Public Works Department, written commun., 2006). Advance warning of high-turbidity events is needed to prepare alternative treatment processes or, when turbidity is too high, for shutting down facility operations.

After the turbidity-induced problems of 1996, the City of Salem determined that it needed real-time water-quality monitoring for the North Santiam River basin. In 1998, the City of Salem entered into a cooperative agreement with the U.S. Geological Survey (USGS) to establish a near real-time, continuous streamflow and water-quality monitoring network in the basin. The network alerts water-treatment-facility operators of high-turbidity events and provides data that help identify sources of sediment and persistent turbidity- information that may help land managers minimize the effect of high-turbidity events in the future. In general, high-turbidity events were rare: during the entire period of record, less than 1 percent of all instantaneous turbidity values were greater than $100 \mathrm{FNU}$.

\section{Program History and Monitoring Locations}

Between October 1998 and June 2001, water-quality instruments were installed at eight stations, either in conjunction with existing streamflow-gaging stations or at new sites. The network has eight monitoring stations (table 1), four upstream of Detroit Lake (upper basin) and four downstream (lower basin) (fig. 1), which measure water temperature, specific conductance, $\mathrm{pH}$, and turbidity by using YSI multiparameter datasondes (YSI Incorporated, 2007). Instantaneous streamflow also is measured at these locationsexcluding Geren Island. Data are logged every 15 minutes and transmitted as many as eight times a day. Data from these water-quality monitoring stations are accessible from the USGS North Santiam Project website at http://or.water.usgs. gov/santiam/.

Table 1. Streamflow-gaging and water-quality monitoring stations used to collect water-quality samples in the North Santiam River basin, Oregon.

[Locations of streamflow-gaging stations are shown in figure 1. Abbreviations: $\mathrm{mi}^{2}$, square mile; N/A, not applicable]

\begin{tabular}{|c|c|c|c|c|c|}
\hline \multirow[b]{2}{*}{$\begin{array}{c}\text { USGS } \\
\text { station No. }\end{array}$} & \multirow[b]{2}{*}{ Station name } & \multirow[b]{2}{*}{ Station reference } & \multirow{2}{*}{$\begin{array}{c}\text { Drainage } \\
\text { basin area } \\
\left(\mathrm{mi}^{2}\right)\end{array}$} & \multicolumn{2}{|c|}{ Streamflow-gaging station } \\
\hline & & & & $\begin{array}{c}\text { Period of } \\
\text { record } \\
\text { (water year) }\end{array}$ & $\begin{array}{l}\text { Years of } \\
\text { record }\end{array}$ \\
\hline \multicolumn{6}{|c|}{ Upper basin stations } \\
\hline 14178000 & $\begin{array}{l}\text { North Santiam River below } \\
\text { Boulder Creek, near Detroit }\end{array}$ & North Santiam & 216 & $\begin{array}{l}\text { 1908-1909, } \\
1929-2004\end{array}$ & 78 \\
\hline 14179000 & $\begin{array}{l}\text { Breitenbush River above French } \\
\text { Creek, near Detroit }\end{array}$ & Breitenbush & 108 & $\begin{array}{l}\text { 1933-1987, } \\
1999-2004\end{array}$ & 61 \\
\hline 14179100 & French Creek near Detroit & French & 10 & 2002-2004 & 3 \\
\hline 14180300 & Blowout Creek near Detroit & Blowout & 26 & 1999-2004 & 6 \\
\hline \multicolumn{6}{|c|}{ Lower basin stations } \\
\hline 14181500 & North Santiam River at Niagara & Niagara & 453 & $\begin{array}{l}\text { 1909-1920, } \\
1922, \\
1939-2004\end{array}$ & 79 \\
\hline 14182500 & $\begin{array}{l}\text { Little North Santiam River near } \\
\text { Mehama }\end{array}$ & Little North & 112 & $1932-2004$ & 73 \\
\hline 14183000 & North Santiam River at Mehama & Mehama & 655 & $\begin{array}{l}1905-07,1911, \\
1921-2004\end{array}$ & 91 \\
\hline 4447281224500 & $\begin{array}{l}\text { North Santiam River at Geren } \\
\text { Island, near Stayton }\end{array}$ & Geren Island & 688 & N/A & N/A \\
\hline
\end{tabular}




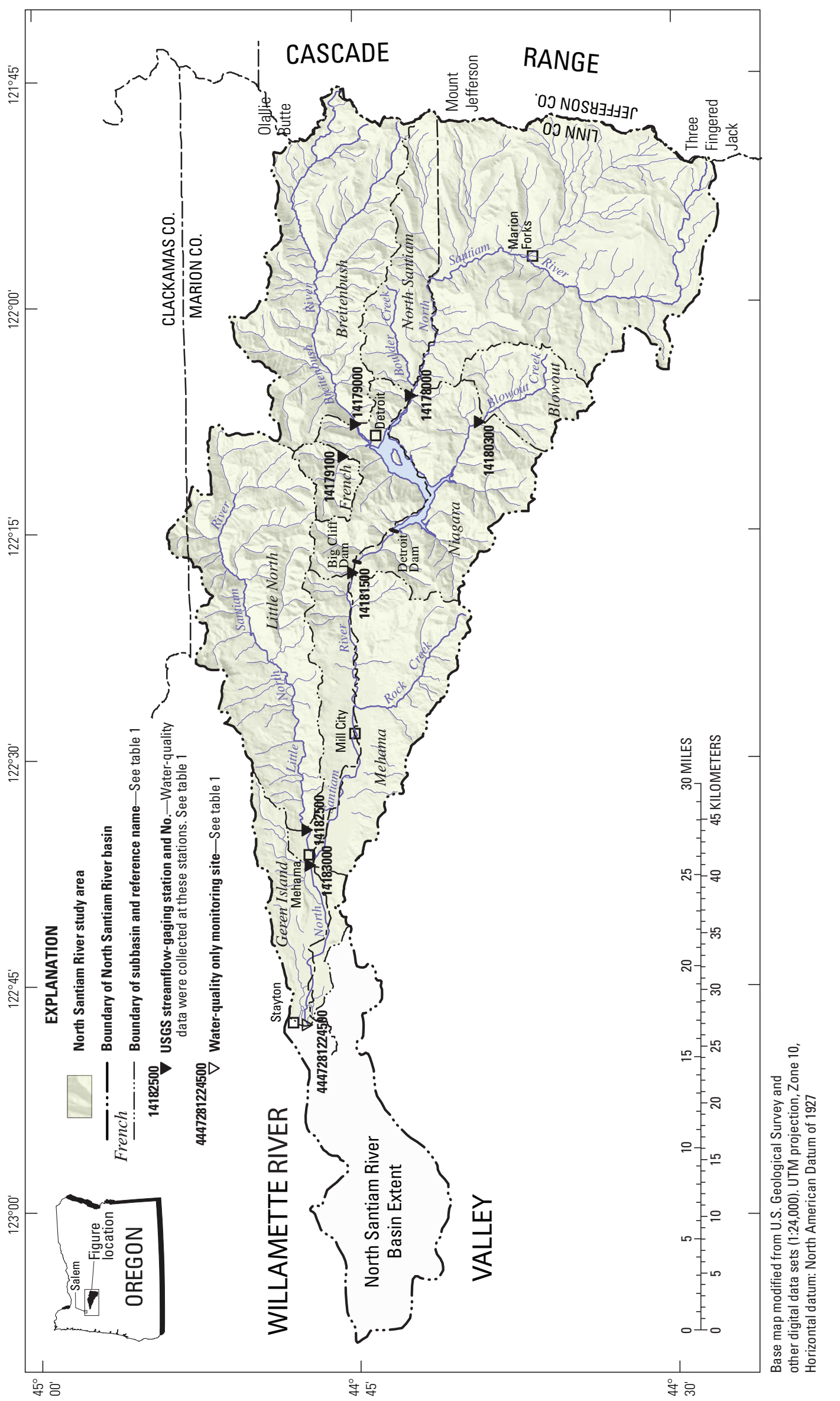

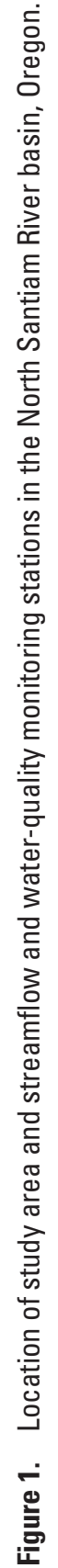




\section{Purpose and Scope}

The purpose of this report is to describe the major turbidity events that occurred in the North Santiam River basin during water years 1999-2004 (October 1998 through September 2004). Major turbidity events are defined for this report as periods when turbidity values were greater than 250 FNU (Formazin Nephelometric Units, see section,
"Definition and Measurement of Turbidity") and the source of the sediment responsible for the elevated turbidity was known. The major turbidity events at five water-quality monitoring stations on unregulated streams are shown in figure 2. The three monitoring stations on the mainstem of the North Santiam River downstream of Detroit and Big Cliff Dams are not included because the dams alter the hydrologic conditions.
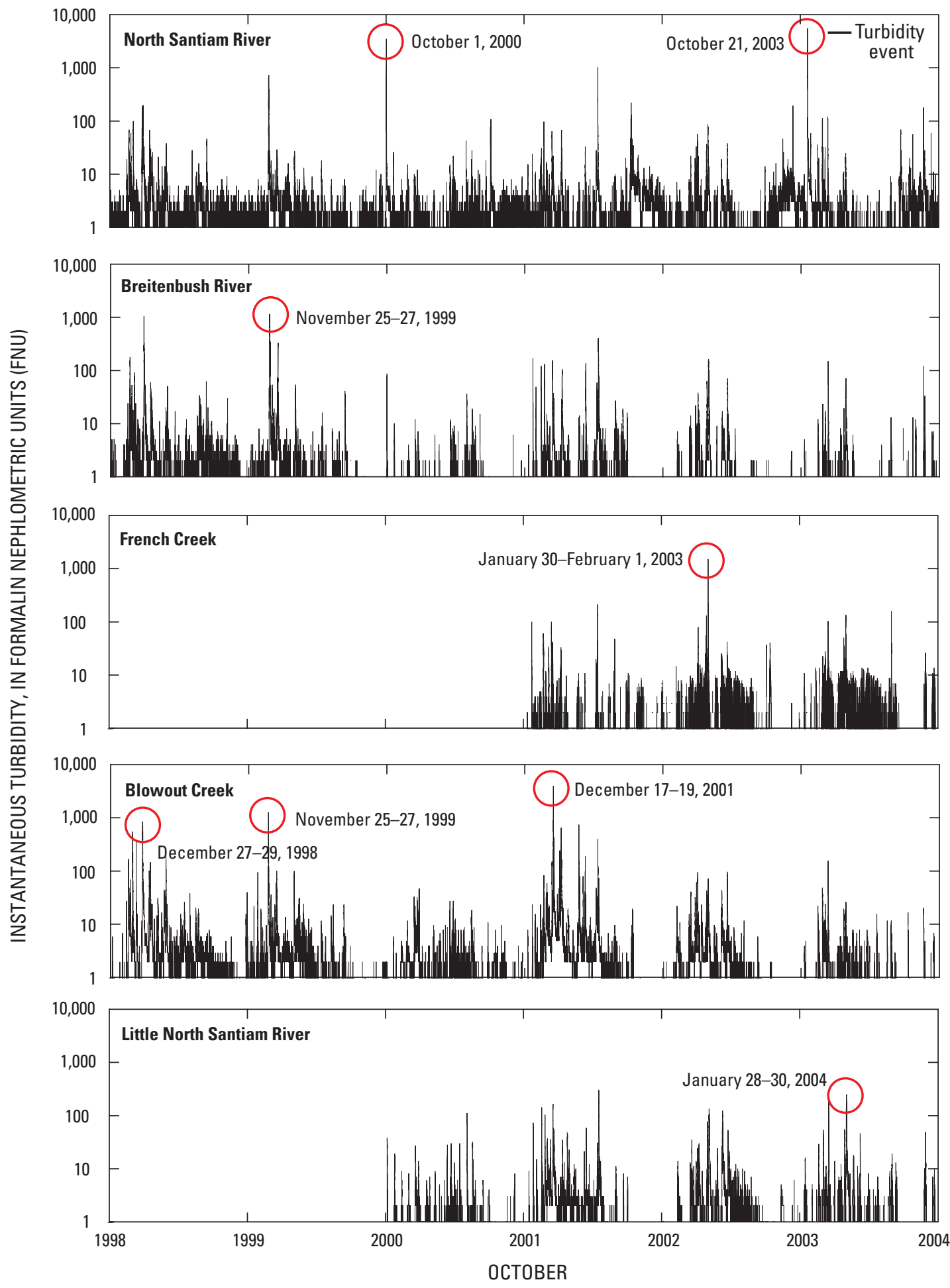

Figure 2. Turbidity records for major turbidity events in five unregulated streams in the North Santiam River basin, Oregon, water years 1999-2004. Major turbidity events are defined for this report as periods when turbidity values were greater than $250 \mathrm{FNU}$. 


\section{Description of North Santiam River} Basin

The North Santiam River originates on the western slope of the Cascade Range and flows $98 \mathrm{mi}$ westward before reaching its confluence with the South Santiam River, southeast of Salem. Streamflow is regulated by two U.S. Army Corps of Engineer dams, Detroit and Big Cliff Dams. The North Santiam River basin includes parts of Linn, Marion, and Clackamas Counties in northwestern Oregon (fig. 1). The study area extends from Mount Jefferson and the High Cascades in the east to Geren Island near Stayton in the west. The study area drains $688 \mathrm{mi}^{2}$, omitting the $90 \mathrm{mi}^{2}$ area downstream of the gaging station at Geren Island. Altitudes in the basin range from 10,500 ft at the Mount Jefferson summit to just more than $500 \mathrm{ft}$ along the Willamette River valley floor in the east.

\section{Land Cover}

The U.S. Forest Service (USFS) manages most of the land in the North Santiam River basin, with the Willamette National Forest covering 69 percent and Mt. Hood National Forest covering an additional 1.5 percent (fig. 3). The rest of the basin is private ( 18 percent), State owned ( 7 percent, managed by the Oregon Department of Forestry), Federally owned (4 percent, managed by the Bureau of Land Management), and tribal land in the Warm Springs Indian Reservation (less than 1 percent). With roughly 75 percent of the basin forested (U.S. Geological Survey, 2005), timber harvesting and recreation are the primary land uses; however, low-altitude valley bottoms sustain agriculture and residential development (fig. 4).

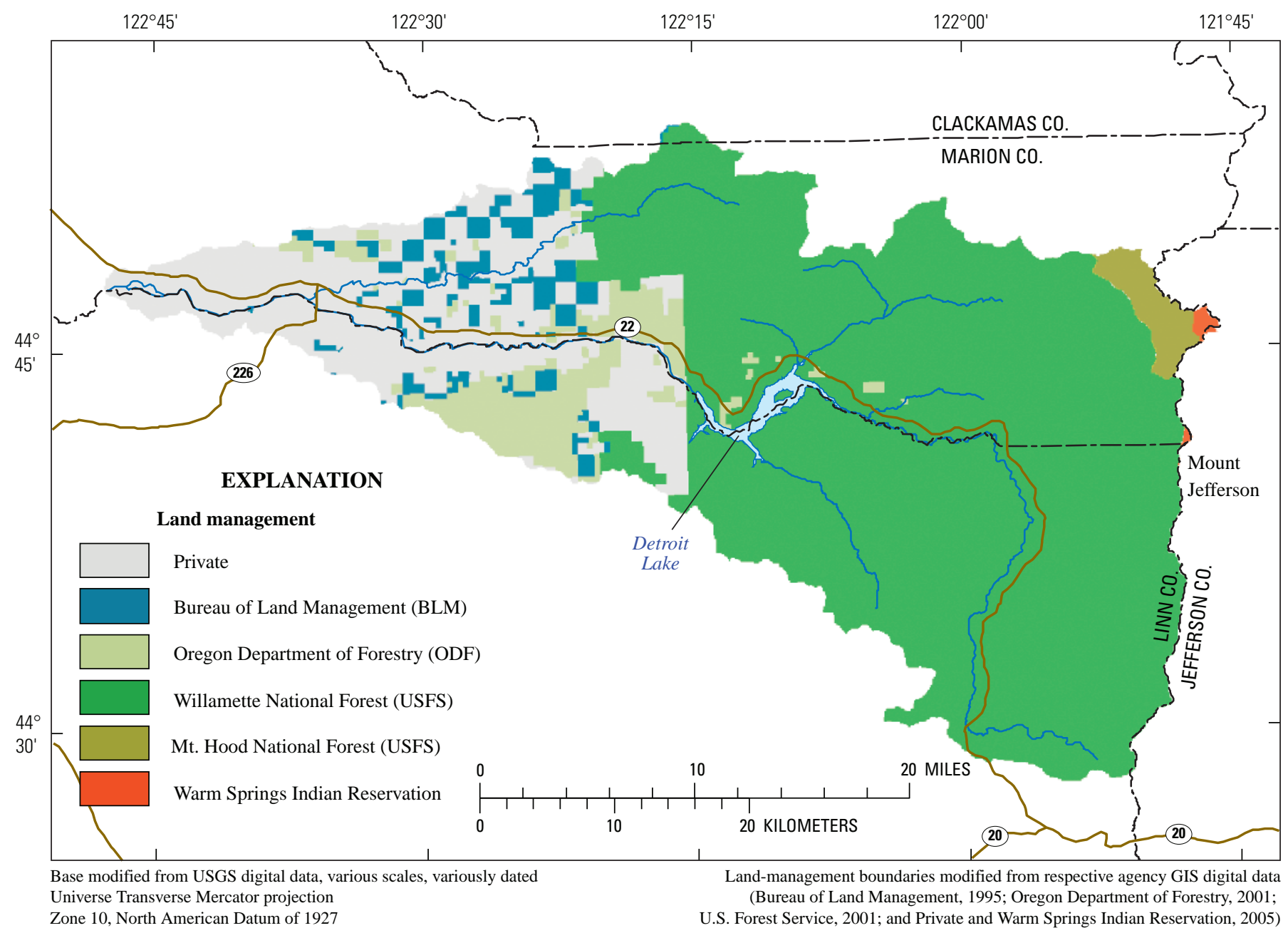

Figure 3. Land management in the North Santiam River basin, Oregon. 


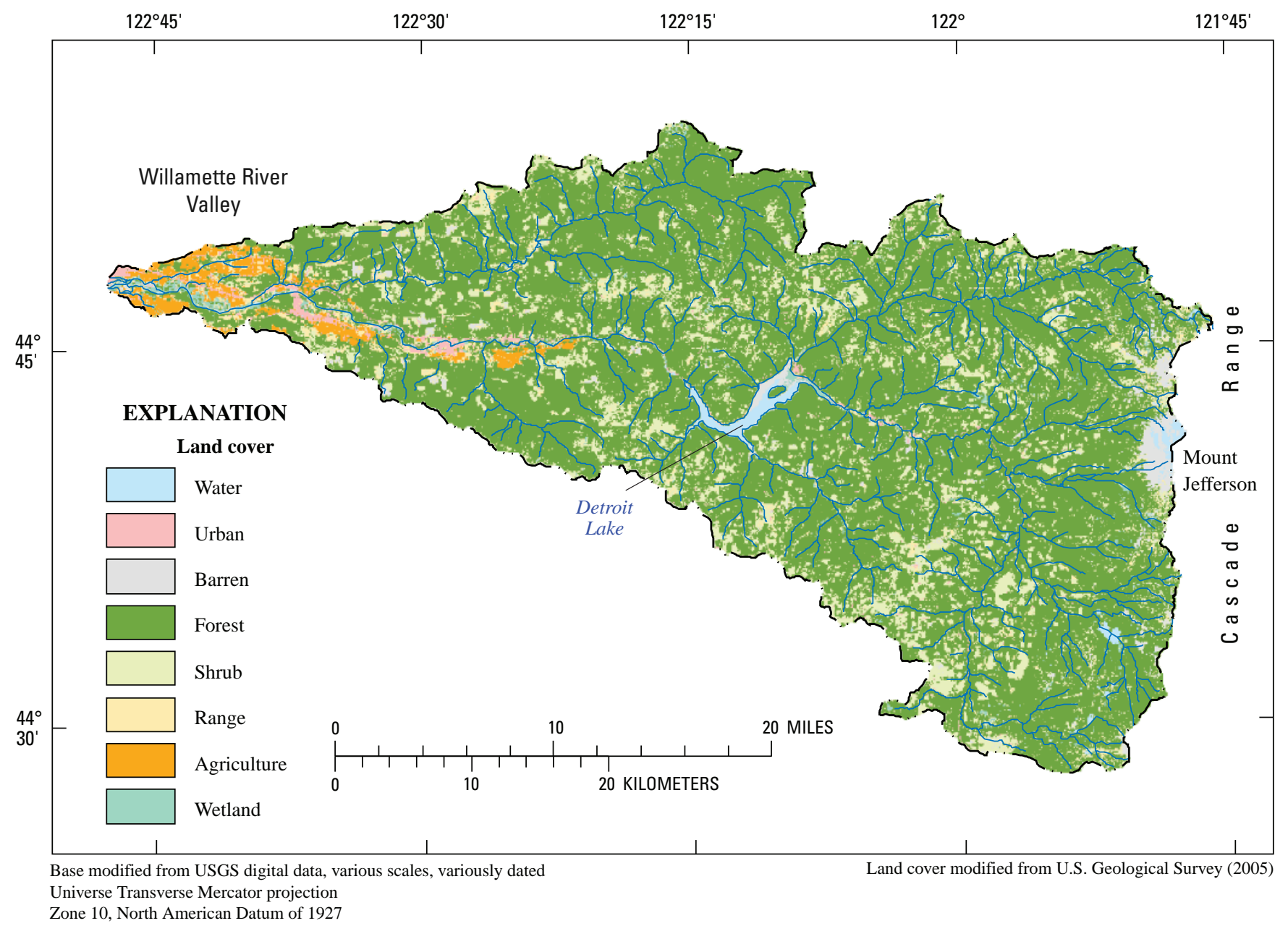

Figure 4. Land cover in the North Santiam River basin, Oregon.

\section{Geology}

The geology of the North Santiam River basin (Walker and MacLeod, 1991; Sherrod and Smith, 2000) is mostly volcanic, with three distinct regions: High Cascades, Western Cascades and Foothills, and Willamette Valley (fig. 5). High Cascade geology is relatively young (Pliocene to Holocene in age), less eroded, and currently volcanically active. Bedrock consists mostly of basalts of Tertiary and Quaternary age, with outcrops of andesite and dacite, mafic vent complexes, and basaltic and andesitic ejecta. Surficial geology includes glacial outwash and related glaciofluvial deposits with ages younger than 140,000 years. Because of the young, less-weathered bedrock and the minimal amount of surface sediments, less sediment is transported from the upper basin than from elsewhere in the North Santiam River basin. However, isolated, glacially derived turbidity events can occur when landslides or glacial outwash release sediment into streams.

The Western Cascades are older, heavily eroded volcanic and sedimentary rocks of Pliocene and Eocene age—primarily Tertiary-age andesites with minor Tertiary-age intrusives and dacites. These heavily eroded materials mobilize during rainfall and cloud mid- to lower-basin streams. Other rock types in the Western Cascades include older basaltic and basaltic andesite lava flows and breccias. Lower, in the Foothills, undifferentiated Miocene-age flows and clastic rocks, Quaternary-age terrace deposits and lag gravels, and landslide and debris flow deposits are common. It is this midaltitude, central basin region in which most of the landslides 


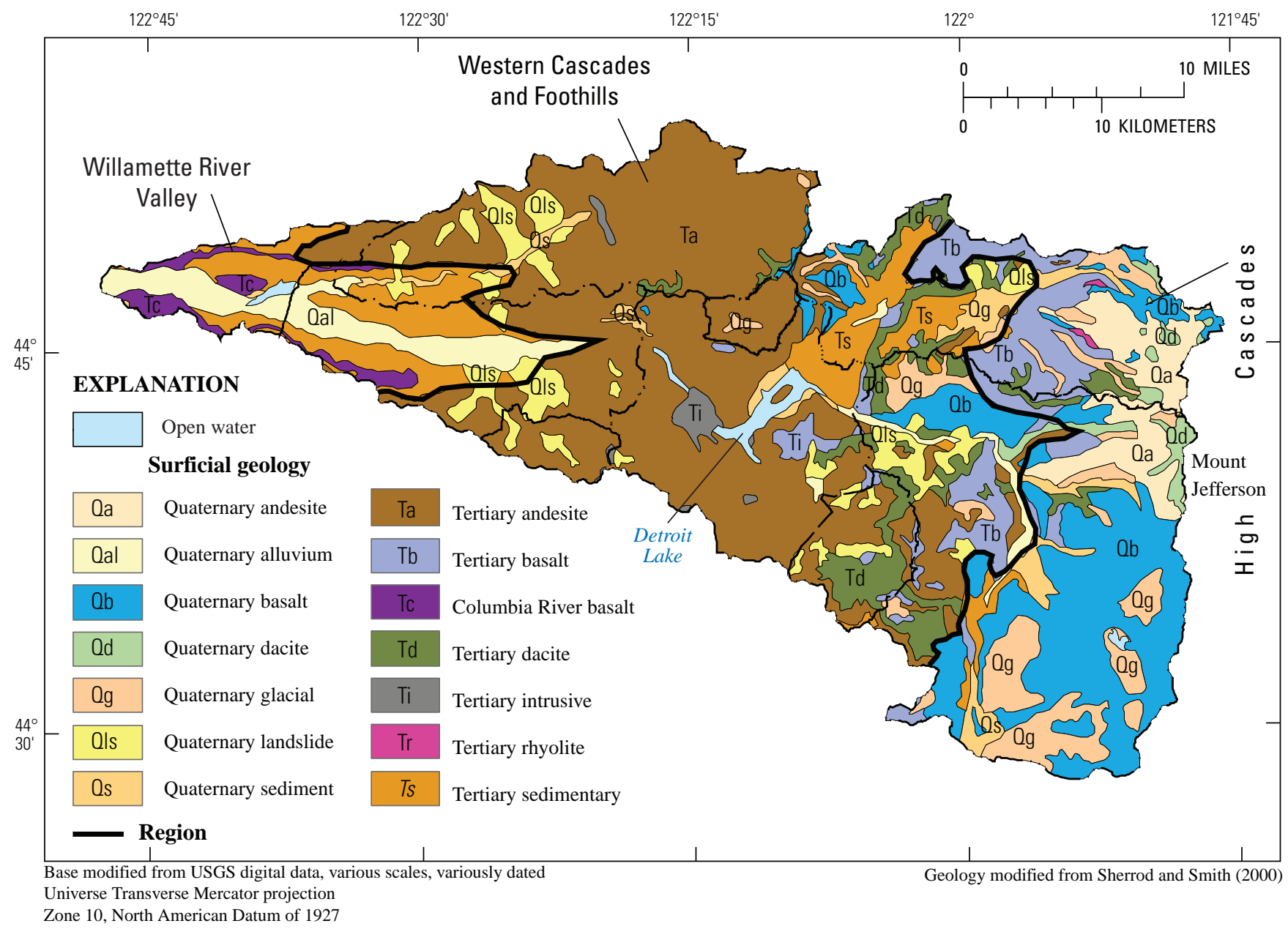

Figure 5. Surficial geology of the North Santiam River basin, Oregon.

occur, with several documented historic landslides, earthflows, and road failures (U.S. Forest Service, 1998; U.S. Forest Service, 1999a; U.S. Forest Service, 1999b; Hofmeister, 2000; Sherrod and Smith, 2000; Shank, 2004).

The geology of the Willamette River Valley is dominated by Columbia River basalts of mid-Tertiary age and sedimentary rocks of mid- to late-Tertiary age. Quaternaryage alluvium and colluvium deposits are present on the valley floor. In the lower valley, surface erosion and remnant landslide material (stabilized landslides) supply sediment to streams. The gradual and low-gradient slopes are stable and much less prone to erosion and landsliding than the midaltitude Western Cascades and Foothills.

\section{Climate}

The North Santiam River basin typically is warm and dry in the summer and cool and rainy in the winter, with snowfall at high altitudes. Mean annual precipitation at rain gages in the basin ranges from 40 in. at Salem to 90 in. at Detroit Dam (9 in. of snow), with greater snowfall at higher altitudes91 in. at Marion Forks (Oregon Climate Service, 2006). About one-half of the precipitation in the High Cascades seeps into the ground-water system, with the amount of infiltration decreasing at lower altitudes (Sherrod and others 1996; Uhrich and Bragg, 2003). Rainfall is the primary catalyst for dislodging sediment for increasing turbidity in streams in the basin. 


\section{Methods of Data Collection and Analysis}

\section{Suspended Sediment}

Methods of data collection and analysis used were based on USGS standards (Rantz, 1982; Edwards and Glysson, 1999; Wilde and others, 1999; Uhrich and Bragg, 2003; Wagner and others, 2006). More than 800 suspended-sediment samples were collected from all locations (excluding Geren Island) during water years 1999-2006. In addition, more than 300 automatic pumping samples were collected and analyzed for suspended sediment at the three monitoring stations in the upper basin (North Santiam, Breitenbush, and Blowout) when turbidity exceeded predetermined thresholds. Most suspendedsediment samples were collected by the equal-width increment method, although 1-L dip samples also were collected when conditions were unsafe (Edwards and Glysson, 1999). At times, additional cross-sectional dip samples were collected in conjunction with the equal-width increment samples. The dip-sampling procedure provided a simple and less timeconsuming method of providing additional data points to verify the equal-width increment concentrations.

Regression models were developed between the measured suspended-sediment concentrations and the instream turbidity measurements, allowing turbidity to be used as a surrogate for suspended-sediment concentration. The development of these regressions for each monitoring location was described fully in Uhrich and Bragg (2003) and updated in Bragg and others (2007). The regression models used to estimate suspended-sediment concentrations at the five unregulated stream monitoring locations discussed in this report are shown in table 2. The calculation of suspended-sediment concentration for the Little North Santiam River, prior to installation of the water-quality monitor, required an additional step. Because turbidity values were not measured prior to 2001, the continuous turbidity and streamflow data from 2001 through 2005 were used to create a regression between the two parameters. Then the continuous streamflow data from 1998 through 2000 were used to estimate turbidity. Those estimated turbidity values were used to calculate suspended-sediment concentrations and suspended-sediment loads.
Table 2. Regression models used to estimate suspendedsediment concentration from instream turbidity measurements on five unregulated streams in the North Santiam River basin, Oregon, waters years 1999-2006.

[A bias-correction factor is included (Bragg and others, 2007). SSC, suspended-sediment concentration; T, turbidity]

\begin{tabular}{llr}
\hline \multicolumn{1}{c}{ Station name } & Regression equation & R $^{2}$ value \\
\hline & Upper basin stations & \\
\hline North Santiam & $\mathrm{SSC}=1.75 \times \mathrm{T}^{1.04}$ & 0.893 \\
Breitenbush & $\mathrm{SSC}=1.80 \times \mathrm{T}^{1.08}$ & .915 \\
French & $\mathrm{SSC}=1.25 \times \mathrm{T}^{1.01}$ & .824 \\
Blowout & $\mathrm{SSC}=1.35 \times \mathrm{T}^{1.18}$ & .928 \\
\hline & Lower basin station \\
\hline Little North & $\mathrm{SSC}=1.78 \times \mathrm{T}^{1.02}$ & \\
\hline
\end{tabular}

Suspended-sediment loads were calculated by using the following equation:

$$
S S L=S S C \times Q \times C,
$$

where

SSL is suspended-sediment load, in tons/30 min.,

SSC is suspended-sediment concentration, in $\mathrm{mg} / \mathrm{L}$,

$Q$ is streamflow, in $\mathrm{ft}^{3} / \mathrm{s}$, and

$c$ equals 0.0000562(Porterfield,1972).

The 30-minute suspended-sediment load values were summed to estimate the daily load. For each water year (from October 1 to September 30), the daily suspended-sediment load values were then summed to provide annual loads for each station. In addition, suspended-sediment loads and yields were calculated for each major turbidity event period. Yields were calculated by dividing the suspended-sediment load by each subbasin drainage area. Suspended-sediment yields allowed for more direct comparison across subbasins by normalizing for drainage basin size. 


\section{Definition and Measurement of Turbidity}

Turbidity is an optical property defined as the measurement of light commonly scattered at 90 degrees to the incident light by suspended particles in an aqueous medium (Uhrich and Bragg, 2003). Suspended sand, silt, and clay or other organic material can decrease water clarity by increasing turbidity. Turbidity is measured according to a variety of methods, both as obtained in the laboratory or in direct instream installations. Each method uses different technology, yields different results, and has its own advantages. The USGS reduced the ambiguity in turbidity measurement by defining a suite of reporting units: the most common instruments measuring in Nephelometric Turbidity Units (NTU), Formazin Nephelometric Units (FNU), and Nephelometric Turbidity Ratio Units (NTRU) (Anderson, 2005). Most instream turbidimeters measure turbidity in FNU using an infrared or monochrome light source (780-900 nanometers), whereas most laboratory instruments measure turbidity in either NTU or NTRU using white or broadband light (400680 nanometers). Equipment that measures in FNU or NTU has one detector and measures the scattered light roughly perpendicular to the incident light. Equipment that measures in NTRU uses a combination of detectors that measure light at 90 degrees (or other angles) and calculate a ratio between detectors. The USFS, City of Salem, and the U.S. Army Corps of Engineers primarily use instruments that measure in NTU, whereas the USGS field equipment measures in FNU and lab equipment in NTRU. Different turbidity units are cited throughout this report, with the unit used depending on which agency collected the data.

\section{Description of Persistent Turbidity and Clay-Water}

\section{Persistent Turbidity}

The most problematic turbidity issue for the watertreatment facility is high-turbidity events of long duration. These events result from prolonged rainfall eroding or mobilizing clay-rich sediment sources in the North Santiam River basin. The clays introduced to streams include very small, less-than-0.05- $\mu \mathrm{m}$ (micron) smectite, halloycite, and kaolinite (Bates and others, 1998; Hulse and others, 2002; Georg Grathoff, Portland State University, written commun, 2004). These particles can absorb water, expand, and remain suspended for extended periods as "persistent" turbidity. Persistently turbid conditions create problems because small particles pass through water-treatment filters, requiring expensive flocculating materials to aid settling. In addition, turbidity levels can remain elevated for days to weeks, adding to the delay and expense in providing a cost-effective water supply.

In order to measure persistent turbidity, more than 230 storm and high-flow samples were collected. Persistent turbidity was defined as having turbidity greater than 10 NTRU at a specified water depth after 8.5 hours. The 10 NTRU value was selected because it was a comparable value of turbidity at which potential alternative processing measures would be taken at the water-treatment facility. The 8.5 hours of settling was determined as the time $0.002-\mathrm{mm}$ (clay-sized) particles take to settle a known distance under controlled laboratory conditions. A suite of laboratory "turbidity-decay curves" were developed for each of the monitoring stations on the basis of all samples collected at its location. The initial turbidity value of each turbidity-decay curve (time $=0.01$ hours) and the persistent turbidity (time $=$ 8.5 hours) were used to develop regression models for each monitoring station (table 3 ).

Using the regression models and setting the persistent turbidity equal to 10 NTRU, a critical initial turbidity (the turbidity value that would produce a persistent turbidity of 10 NTRU after 8.5 hours of settling) was determined for each monitoring station. That value was converted to FNU by using another regression model. The final threshold turbidity values were as follows: French, 170 FNU; Breitenbush, 89 FNU; Blowout, 76 FNU; Little North, 69 FNU; and North Santiam, 64 FNU (fig. 6).

Table 3. Regression models used to estimate persistent turbidity from initial turbidity on five unregulated streams in the North Santiam River basin, Oregon, water years 1999-2006.

[A bias-correction factor is included (Bragg and others, 2007). PT, persistent turbidity; IT, initial turbidity]

\begin{tabular}{llc}
\hline \multicolumn{1}{c}{ Station name } & Regression equation & $\mathbf{R}^{2}$ value \\
\hline & Upper basin stations & \\
\hline North Santiam & PT $=0.301 \times$ IT 0.950 & 0.889 \\
Breitenbush & PT $=0.402 \times$ IT 0.825 & .926 \\
French & PT $=0.403 \times$ IT 0.721 & .994 \\
Blowout & PT $=0.602 \times$ IT 0.762 & .841 \\
\hline & Lower basin station \\
\hline Little North & PT $=0.310 \times$ IT 0.934 \\
\hline
\end{tabular}




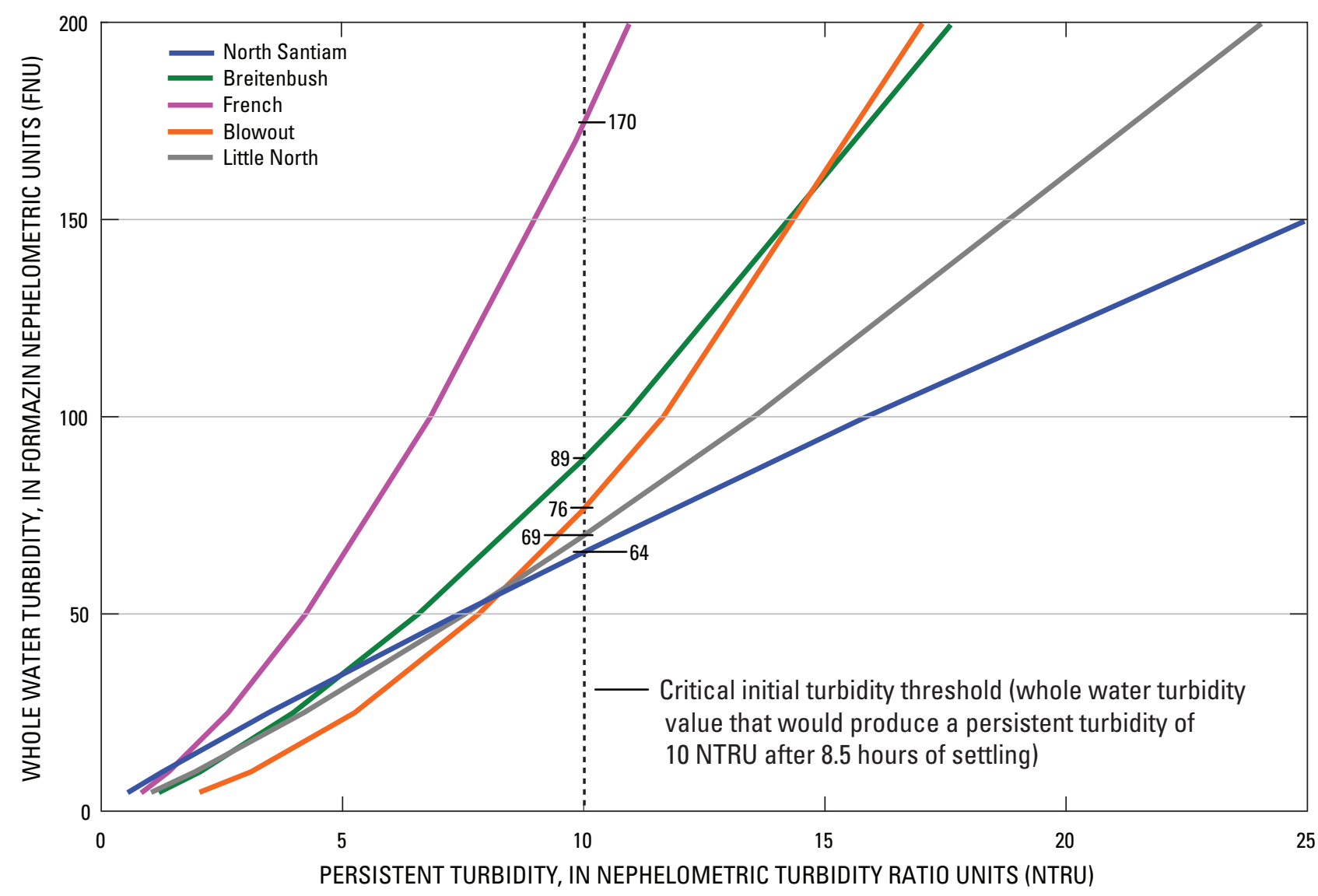

Figure 6. Instream turbidity thresholds for persistent turbidity and clay-water volume estimates at five unregulated streams in the North Santiam River basin, Oregon, water years 1999-2006.

\section{Clay-Water Volume}

Clay-water volume was calculated for each major turbidity event by using the procedures developed by Uhrich and Bragg (2003). When the measured instream turbidity value reached the threshold value, as mentioned above, the volume of water flowing past the monitoring station while the turbidity exceeded the threshold value was calculated. The volumes of clay-water related to each of the major turbidity events, as well as the annual totals for each year, were calculated for all monitoring stations to quantify major sources of clay-water in the basin.

\section{Selection Criteria for Major Turbidity Events}

The eight major turbidity events in this report were selected because they were high-turbidity events (greater than $250 \mathrm{FNU}$ ) that had known origins. Six of the events were precipitation driven, whereas the remaining two were glacially or snowmelt driven. Seven of the major turbidity events occurred upstream of Detroit Lake, where monitors were deployed for the entire period of record. Most of the major turbidity events were evaluated as 3-day events; however, the two glacial outwash (snowmelt-driven) events were single-day events. 


\section{Major Turbidity Events}

\section{December 27-29, 1998—Blowout Creek}

\section{Conditions}

The first major turbidity event recorded in the North Santiam River basin occurred in December 1998, 3 months after the first water-quality monitors were installed in the upper basin. Heavy precipitation during December 27-29 brought 7 to 12 in. of rain to the basin (Oregon Climate Service, 2006). The heavy rain increased streamflow to greater than 2- to 5-year levels (Cooper, 2005), with $8,210 \mathrm{ft}^{3} / \mathrm{s}$ measured at the North Santiam monitoring station, $6,940 \mathrm{ft}^{3} / \mathrm{s}$ at Breitenbush, and 3,780 $\mathrm{ft}^{3} / \mathrm{s}$ at Blowout. Downstream of Detroit Lake, in the lower basin, streamflow reached $18,700 \mathrm{ft}^{3} / \mathrm{s}$ at the Little North monitoring station. Turbidity increased at each of the three upper basin waterquality monitoring stations, as sediment mobilized from the landscape, with values reaching 198 FNU at North Santiam, $1,050 \mathrm{FNU}$ at Breitenbush, and $874 \mathrm{FNU}$ at Blowout (fig. 7). At the time, the only turbidity value available in the lower basin was 195 NTU recorded at Geren Island (Hank Wujcik, City of Salem Public Works Department, written commun., 2005). Aside from streamflow at the Little North Santiam River station, no other USGS water-quality data were available downstream of Detroit Lake because lower basin USGS waterquality monitoring stations were not established until April 2000.

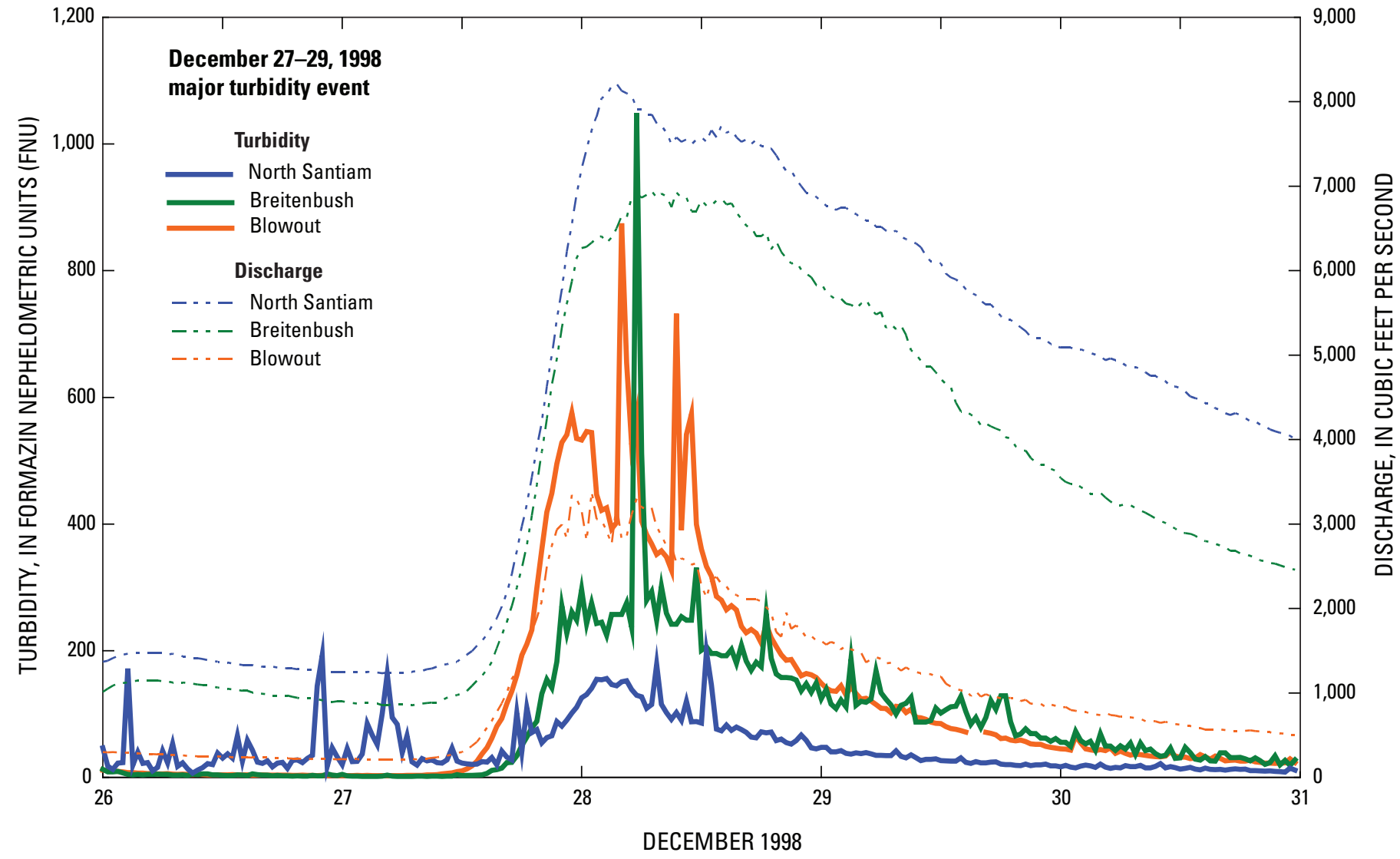

Figure 7. Turbidity and discharge at three upper basin monitoring stations for the December 27-29, 1998, major turbidity event in North Santiam River basin, Oregon. 
Suspended-Sediment Loads and Clay-Water

Volumes and Yields

During the 3-day storm, thousands of tons of sediment were transported by each upper North Santiam River basin stream (table 4). The largest suspended-sediment load transported was the calculated 17,300 $\mathrm{T}$ of material that passed the Breitenbush River station, a yield of $160 \mathrm{ton} / \mathrm{mi}^{2}$. Blowout Creek carried slightly less material at 14,100 tons, but had more than three times the yield at 540 tons $/ \mathrm{mi}^{2}$. This major turbidity event generated the greatest single-event suspendedsediment load transported by Blowout Creek during the entire period of record (October 1998 to September 2004), and the second greatest single-event suspended-sediment yield of any station.

Along with suspended-sediment loads, clay-water volumes were calculated for each stream during the December 1998 storm (table 4). Responding in a similar way as it did to sediment load, the Breitenbush River also carried the largest volume of clay-water of all upper basin streams at 7,020 Mgal. Once again, Blowout Creek transported less clay-water than the larger Breitenbush River; however, similar to suspended-sediment yield, Blowout Creek produced the greatest clay-water yield of the three upper basin stations with $98 \mathrm{Mgal} / \mathrm{mi}^{2}$. Only the Little North Santiam River subbasin had a potentially higher clay-water yield $\left(136 \mathrm{Mgal} / \mathrm{mi}^{2}\right)$; however, the yield was computed using streamflow to estimate turbidity because water-quality data were not yet collected. Therefore, the estimate was different than if it had been calculated using continuous instream turbidity measurements, similar to the other upper basin calculations.

This 3-day event was an indicator of the influence that Blowout Creek has on the North Santiam River basin system. Not only was the Blowout Creek subbasin a major sediment contributor, but it also had the potential for supplying a large amount of clay-size material - the same type of material that can be problematic to the water-treatment facility. Although the settling effect of Detroit Lake is an impediment to the transport of clay-water to the lower basin, during extremely high flows, clay-rich, persistently turbid water can be released downstream through the dam, as in February 1996 (Bates and others, 1998; Hulse and others, 2002).

Table 4. Suspended-sediment load and yield, and clay-water volume and yield for the December 27-29, 1998, major turbidity event in the North Santiam River basin, Oregon.

[Little North values were estimated using discharge as a surrogate for instream turbidity. Abbreviations: ton $/ \mathrm{mi}^{2}$, ton per square mile; Mgal, million gallons; $\mathrm{Mgal} / \mathrm{mi}^{2}$, million gallons per square mile; N/A, no data available because station not yet established]

\begin{tabular}{|c|c|c|c|c|c|c|}
\hline \multirow{2}{*}{$\begin{array}{l}\text { Station } \\
\text { name }\end{array}$} & \multicolumn{3}{|c|}{ Suspended sediment } & \multicolumn{3}{|c|}{ Clay-water } \\
\hline & $\begin{array}{l}\text { Load } \\
\text { (ton) }\end{array}$ & $\begin{array}{l}\text { Percentage of } \\
\text { annual load }\end{array}$ & $\begin{array}{c}\text { Yield } \\
\text { (ton/mi²) }\end{array}$ & $\begin{array}{l}\text { Volume } \\
\text { (Mgal) }\end{array}$ & $\begin{array}{l}\text { Percentage of } \\
\text { annual volume }\end{array}$ & $\begin{array}{c}\text { Yield } \\
(\text { Mgal/mi²) }\end{array}$ \\
\hline \multicolumn{7}{|c|}{ Upper basin stations } \\
\hline North Santiam & 6,240 & 40 & 29 & 4,710 & 85 & 22 \\
\hline Breitenbush & 17,300 & 68 & 160 & 7,020 & 90 & 65 \\
\hline French & N/A & N/A & N/A & N/A & N/A & N/A \\
\hline Blowout & 14,100 & 68 & 540 & 2,550 & 58 & 98 \\
\hline \multicolumn{7}{|c|}{ Lower basin station } \\
\hline Little North & 22,000 & 59 & 200 & 15,200 & 91 & 136 \\
\hline
\end{tabular}




\section{Sources of Turbidity}

After the December storm, field reconnaissance was conducted to determine potential source areas for the increased turbidity and sediment loads in the upper North Santiam River basin. Although no specific source areas were identified for the Breitenbush River or North Santiam River loads, two potential sources were located for the Blowout Creek subbasin (fig. 8). On the basis of USFS (Douglas Shank, U.S. Forest Service, oral commun., 2005; David Klug, U.S. Forest Service, oral commun., 2005) and USGS field observations, the two sources were the Blowout Creek and Divide Creek earthflows (figs. 9 and 10). Although not the only earthflows in the subbasin, both are large and perennial

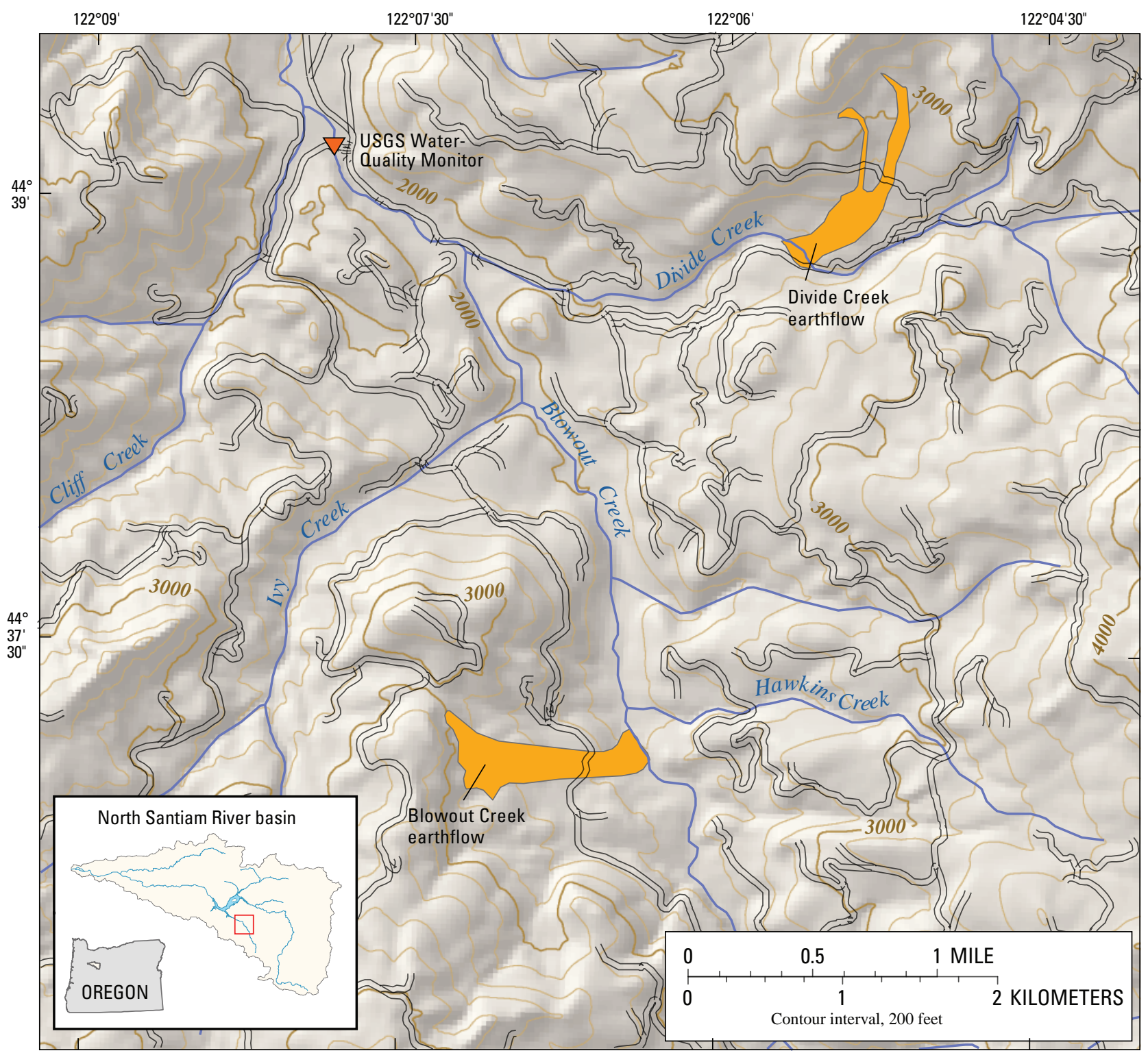

Base modified from USGS digital data, various scales, variously dated

Earthflow mapped by Shank (2004)

Universe Transverse Mercator projection

Zone 10, North American Datum of 1927

Figure 8. Location of Blowout Creek and Divide Creek earthflows in the Blowout Creek subbasin of the North Santiam River basin, Oregon. 
sources of sediment and clay (David Klug, U.S. Forest Service, oral commun., 2005). According to soil surveys of the area (U.S. Forest Service, 1992), the Divide Creek earthflow was considered moderately stable to unstable, with moderate to severe surface soil erosion potential, a high yield potential for silt to clay sediment, and high water detention storage capacity. In contrast, the Blowout Creek earthflow was described as mostly stable but with severe soil erosion and high runoff potential, and a low silt-clay yield. Both earthflows are part of Holocene and Pleistocene-age landslide and debris flow deposits (Walker and MacLeod, 1991).

Although there had been some tree harvesting in the vicinity, the earthflows were mostly forested, with some barren land and shrub coverage (U.S. Geological Survey, 2005). The bulk of the sediment, clay load, and related turbidity was likely caused by material from one or both of these locations, with some additional contribution from upstream areas.

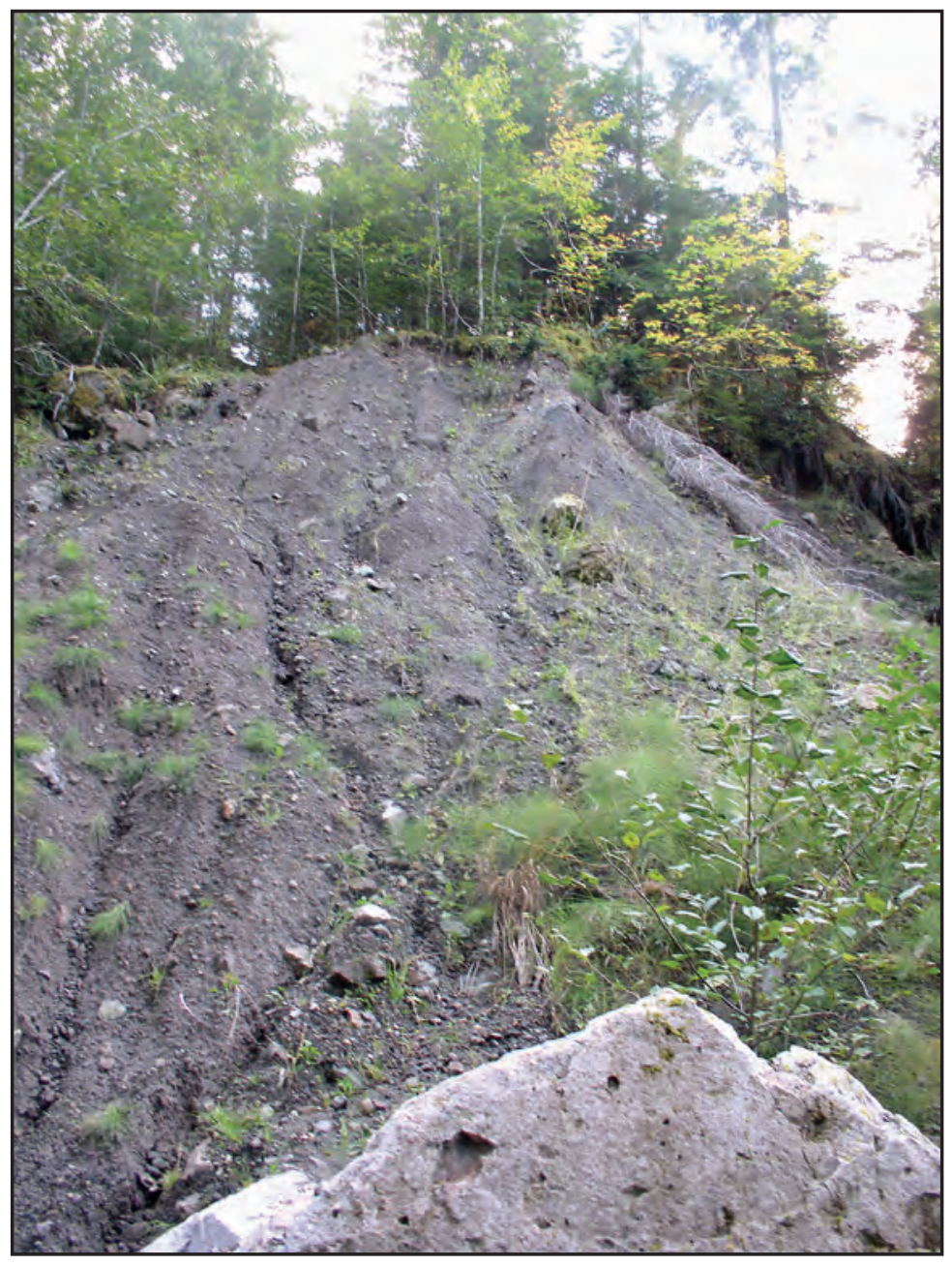

Figure 9. Blowout Creek earthflow in the Blowout Creek subbasin of the North Santiam River basin, Oregon. (Photograph by U.S. Geological Survey, taken in 2004). 


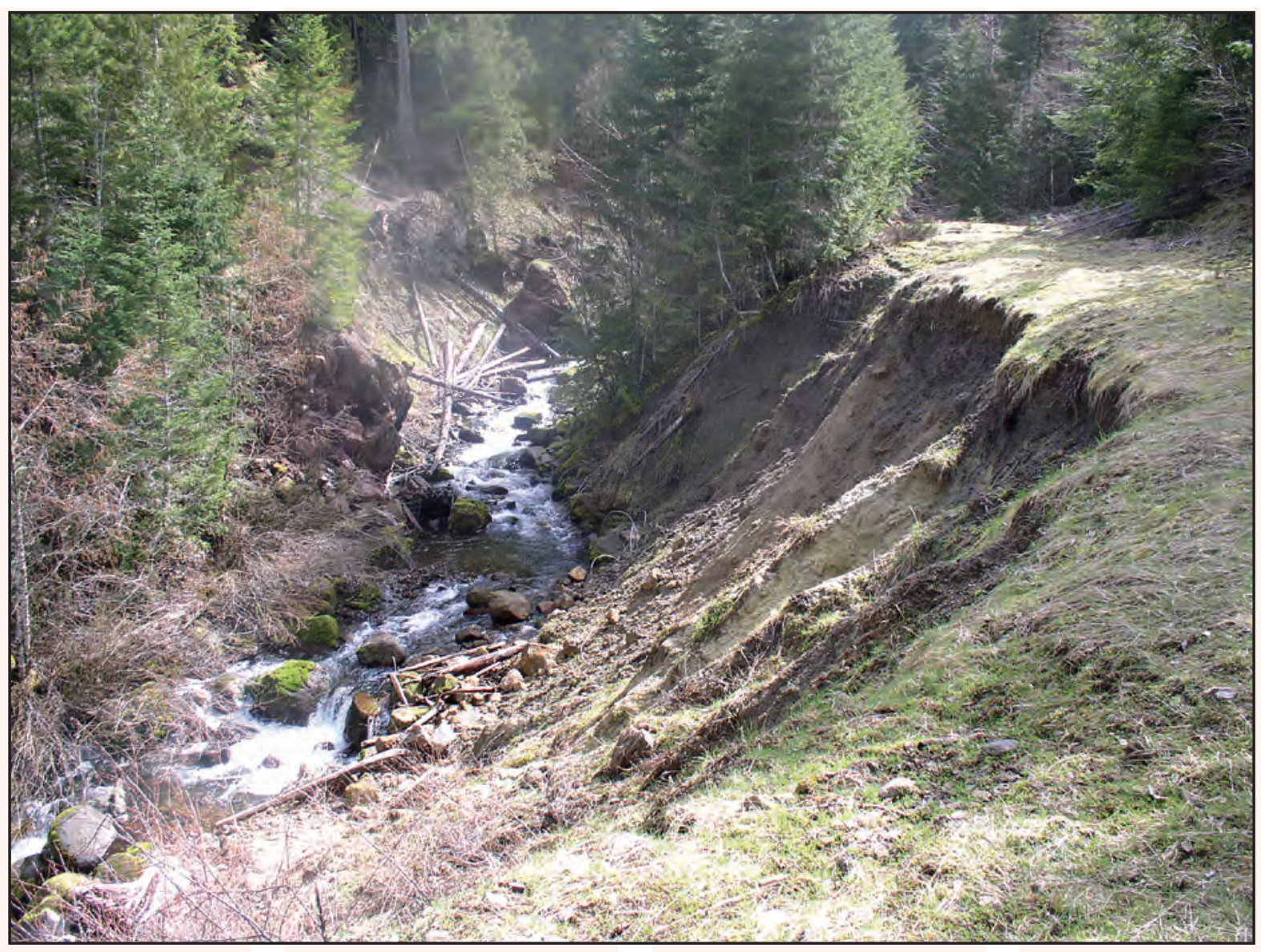

Figure 10. Divide Creek earthflow in the Blowout Creek subbasin of the North Santiam River basin, Oregon. (Photograph by U.S. Geological Survey, taken in 2004).

\section{Follow-Up Investigations}

Since the inception of the study, Blowout Creek has become one of the most studied subbasins in the North Santiam River basin. Although the stream drains a small area, it often has high turbidity during precipitation events. In order to determine whether certain sources supply most of the sediment, temporary water-quality monitors were installed during several periods at different locations within the subbasin. For example, water-quality monitors were placed downstream of the Divide Creek earthflow, upstream of the Blowout Creek earthflow, downstream of the Blowout Creek water-quality monitor, and near the mouth of Cliff Creek (a tributary to Blowout Creek). To date, data from these additional monitors has not conclusively linked subsequent episodes of increased turbidity solely to these specific source areas. Along with monitoring water quality, attempts at monitoring both Blowout and Divide Creek earthflows also have begun. As part of the preliminary investigation, sediment samples have been collected from each earthflow. An inclinometer and calibrated stake-arrays also have been placed at the Blowout Creek earthflow to measure movement. 


\section{November 25-27, 1999—Breitenbush River and Blowout Creek}

\section{Conditions}

The next two major turbidity events occurred a year later, but in separate subbasins. In late November 1999, a large storm system in the North Santiam River basin increased streamflows to 5- to 50-year recurrence intervals (Cooper, 2005). The upper North Santiam River had a 5- to 10-year event, Breitenbush River a 10- to 25-year event, and the Little North Santiam River, the highest, with a 25- to 50-year recurrence interval. According to rainfall records at Detroit
Dam, almost 9 in. of rain fell during the first 2 days of the storm-November 25-26-with an additional $0.5 \mathrm{in}$. falling on November 27 (Oregon Climate Service, 2006). Streamflow at the North Santiam River monitoring station reached $13,300 \mathrm{ft}^{3} / \mathrm{s}$, while streamflow at the Breitenbush and Blowout stations reached $11,200 \mathrm{ft}^{3} / \mathrm{s}$ and $2,670 \mathrm{ft}^{3} / \mathrm{s}$, respectively.

The highest flow recorded at Little North monitoring station was $28,900 \mathrm{ft}^{3} / \mathrm{s}$. During the storm, rivers became extremely turbid. For example, turbidity at North Santiam reached $739 \mathrm{FNU}$, while reaching 1,160 and 1,310 FNU at the Breitenbush and Blowout stations, respectively (fig. 11). Although discharge was recorded at the Little North monitoring station, turbidity was not recorded because the water-quality monitor was not yet installed.

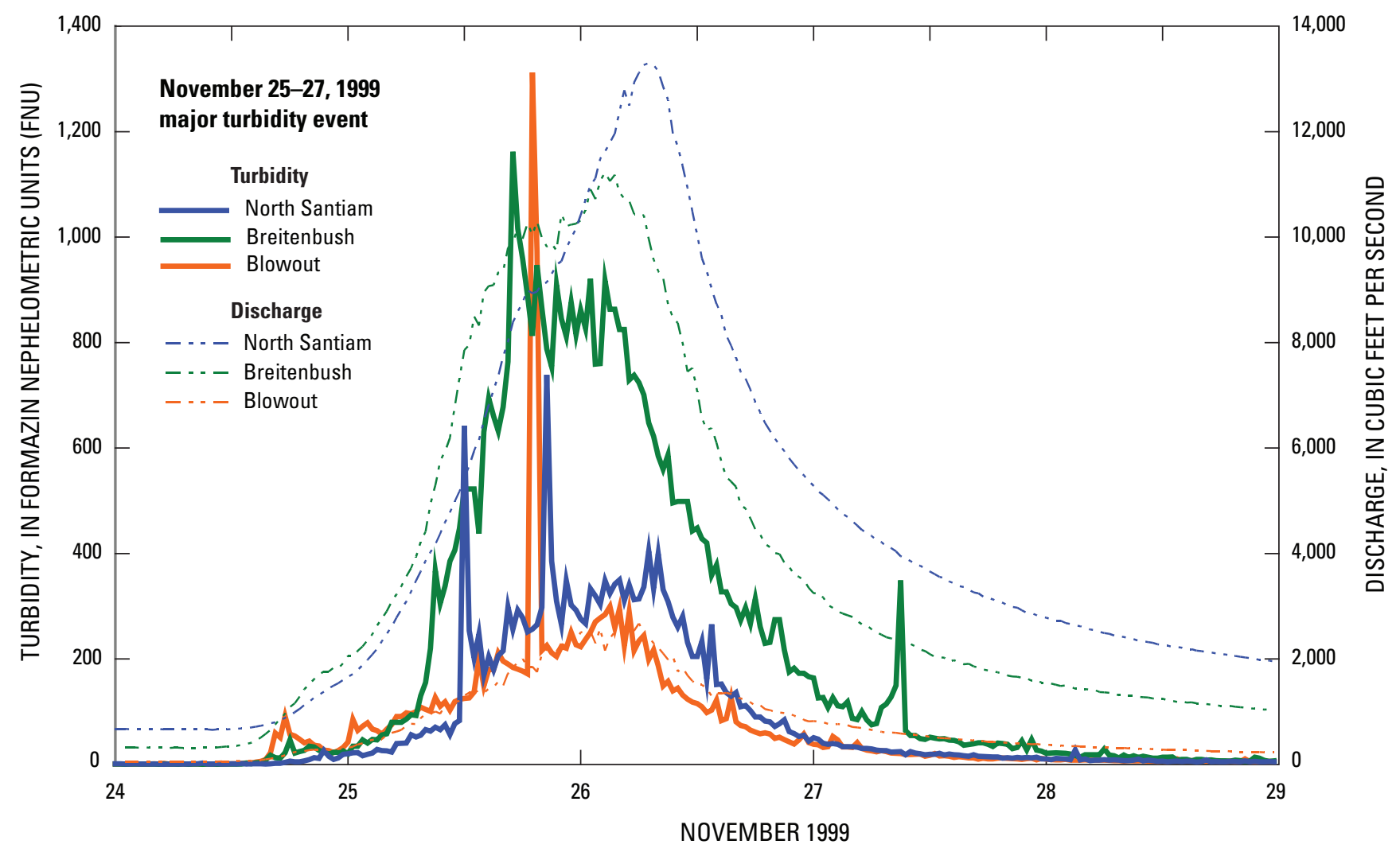

Figure 11. Turbidity and discharge at three upper basin monitoring stations for the November 25-27, 1999, major turbidity event in the North Santiam River basin, Oregon. 
Suspended-Sediment Loads and Clay-Water Volumes and Yields

As with the first major turbidity event, the heavy rainfall increased turbidity and produced high suspended-sediment loads (table 5). The November 1999 major turbidity event for the Breitenbush River was the largest single-event load ever calculated for any station during the study. The 69,800 tons of suspended sediment transported in the river during this event comprised 93 percent of the total annual sediment load for water year 2000 (September 1999-October 2000). Unlike the massive load transported by the Breitenbush River, Blowout Creek moved less than one-tenth of that at 6,060 tons (table 5). This 3-day major turbidity event transported 81 percent of the total annual suspended-sediment load for the Blowout Creek subbasin. Compared to the December 1998 Blowout Creek event, this November 1999 Blowout Creek event transported only about one-half the load, even though it had a higher maximum turbidity $(1,310 \mathrm{FNU})$ than the previous event (874 FNU).

Along with a large suspended-sediment load, the Breitenbush River transported greater than 90 percent of its annual clay-water volume during the November 1999 event (table 5). The clay-water volume reached 9,110 Mgal for the 3-day period, about 98 percent of the annual total. In comparison with December 1998, more than four times the material was displaced and transported from the Breitenbush subbasin during this event. However, the clay-fraction increase was marginal, as the clay-water volume was greater by less than 25 percent. This small difference suggests that the source area supplying the sediment in 1998 was more clay-rich than the source for the 1999 major turbidity event.

Clay-water volume in Blowout Creek during this event was 1,690 Mgal, which equated to about 92 percent of the annual clay-water volume for the station (table 5). This volume was less than that in December 1998, and the least percentage of annual volume of any of the upper basin stations during the November 1999 storm. In addition, although claywater yield increased in all other subbasins as compared to the yield of the 1998 storm, the Blowout Creek subbasin yield actually decreased by 33 percent to $65 \mathrm{Mgal} / \mathrm{mi}^{2}$. The decrease in clay-water volume likely was caused by the short-term antecedent conditions in the subbasin as accumulated, easily erodible material was removed the previous winter.

Table 5. Suspended-sediment load and yield, and clay-water volume and yield for the November 25-27, 1999, major turbidity event in the North Santiam River basin, Oregon.

[Little North values were estimated using discharge as a surrogate for instream turbidity. Abbreviations: ton $/ \mathrm{mi}^{2}$, ton per square mile; Mgal, million gallons; $\mathrm{Mgal} / \mathrm{mi}^{2}$, million gallons per square mile; N/A, no data available because station not yet established]

\begin{tabular}{|c|c|c|c|c|c|c|}
\hline \multirow{2}{*}{$\begin{array}{l}\text { Station } \\
\text { name }\end{array}$} & \multicolumn{3}{|c|}{ Suspended sediment } & \multicolumn{3}{|c|}{ Clay-water } \\
\hline & $\begin{array}{l}\text { Load } \\
\text { (ton) }\end{array}$ & $\begin{array}{l}\text { Percentage of } \\
\text { annual load }\end{array}$ & $\begin{array}{c}\text { Yield } \\
\text { (ton/mi²) }\end{array}$ & $\begin{array}{l}\text { Volume } \\
\text { (Mgal) }\end{array}$ & $\begin{array}{l}\text { Percentage of } \\
\text { annual volume }\end{array}$ & $\begin{array}{c}\text { Yield } \\
\left(\text { Mgal/mi²) }^{2}\right)\end{array}$ \\
\hline \multicolumn{7}{|c|}{ Upper basin stations } \\
\hline North Santiam & 22,200 & 85 & 100 & 8,850 & 100 & 41 \\
\hline Breitenbush & 69,800 & 93 & 650 & 9,110 & 98 & 84 \\
\hline French & N/A & N/A & N/A & N/A & N/A & N/A \\
\hline Blowout & 6,060 & 81 & 230 & 1,690 & 92 & 65 \\
\hline \multicolumn{7}{|c|}{ Lower basin station } \\
\hline Little North & 45,700 & 77 & 410 & 19,700 & 93 & 176 \\
\hline
\end{tabular}




\section{Sources of Turbidity}

As in 1998, the USGS and USFS made field observations to locate source areas that might have supplied sediment to streams in the upper basin. During the investigation, no specific source area was discovered for the turbidity in the upper North Santiam River. However, at least one major landslide that contributed to the sediment load was discovered in the Breitenbush subbasin. In the Blowout Creek subbasin, the Divide or Blowout Creek earthflows again were the likely sources for high turbidity values, as they were in 1998. The landslide in the Breitenbush River subbasin was a recently clear-cut area near East Humbug Creek, a small tributary to the Breitenbush River (fig. 12). The unstable area

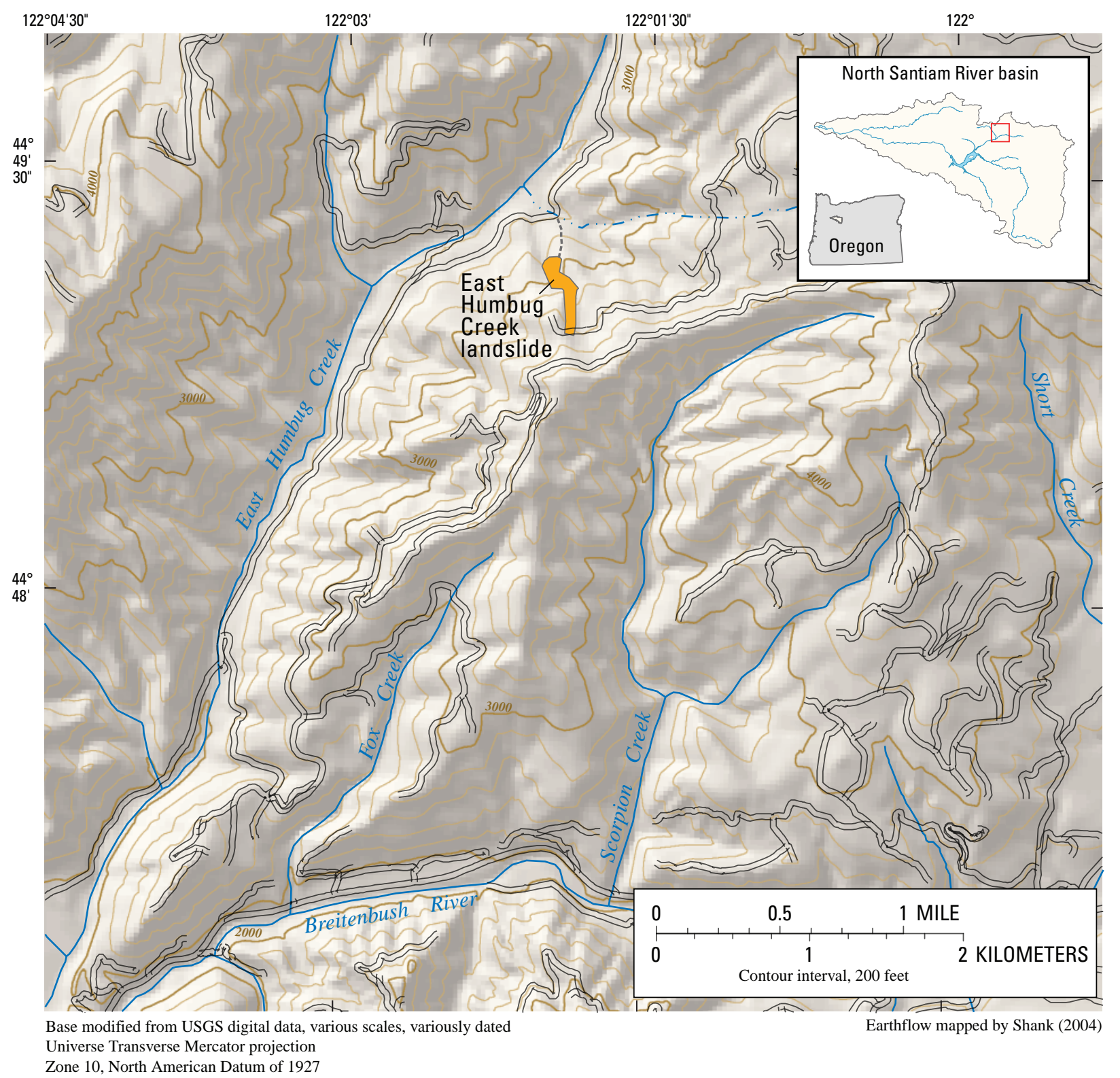

Figure 12. Location of the East Humbug Creek landslide in the Breitenbush River subbasin of the North Santiam River basin, Oregon. 
encompassed 12 acres (fig. 13) and was located 8 mi upstream of the Breitenbush River water-quality monitor. The landslide area was moderately to severely susceptible to surface erosion and had a high potential for supplying silt and clay sediment (U.S. Forest Service, 1992). This landslide was likely an example of older basaltic lava flows and breccias overlying weaker Continental sedimentary and volcaniclastic rocks (Walker and MacLeod, 1991). The landslide, though too small to supply all material that passed the Breitenbush monitoring station, likely was responsible for a portion of the estimated 69,800 tons of material that passed during the 3-day period (David Klug, U.S. Forest Service, oral commun., 2005). No other landslides or potential source areas have yet been discovered in the Breitenbush River subbasin and dated to correspond with this November 1999 major turbidity event.

\section{Follow-Up Investigations}

A previous assessment of the known Breitenbush River subbasin landslide (U.S. Forest Service, [2001]) described the East Humbug Unit 5 Stand as a slide risk. However, trees were harvested in the mid-1990s, leaving the slope susceptible to accelerated surface erosion and landsliding. Before sliding in 1999, the first evidence of movement from this location occurred in 1996 (U.S. Forest Service, [2001]). Since the landslide of November 1999, stabilization efforts such as dewatering by overland drainage pipes, log terracing, and planting of saplings and grasses were completed to limit future mobilization (David Klug, U.S. Forest Service, oral commun., 2005; written commun., 2006). During 2004-05, a temporary water-quality monitor was installed at a decommissioned USGS streamflow-gaging station on East Humbug Creek. During its deployment, data showed instances of increased turbidity in East Humbug Creek, likely related to runoff from the landslide area; therefore, detectable sediment input from the upper East Humbug Creek watershed likely was still occurring.

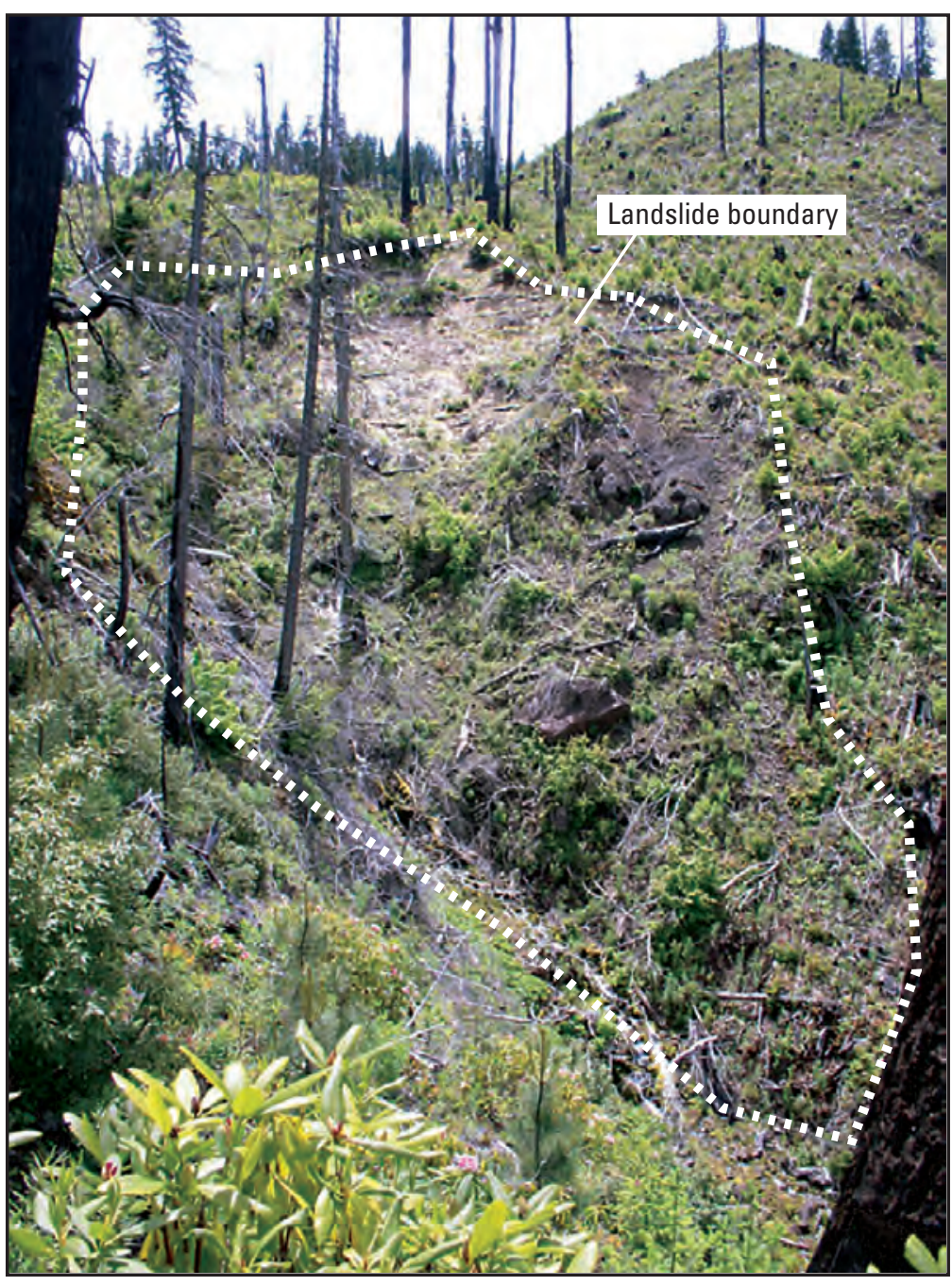

Figure 13. East Humbug Creek landslide in the Breitenbush River subbasin of the North Santiam River basin, Oregon. (Photograph by U.S. Geological Survey, taken in 2004). 


\section{October 1, 2000—North Santiam River}

\section{Conditions}

In late September and early October 2000, unseasonably high temperatures in the North Santiam River basin remained in the mid- to upper 70s (Oregon Climate Service, 2006).

The warm temperatures combined with a minor rainfall event (about an inch of rain) to expedite melt of the High Cascade snowpack. On October 1, streamflow at the North Santiam monitoring station increased slightly but remained less than $600 \mathrm{ft}^{3} / \mathrm{s}$ - normal for early October. Associated with the slight increase in streamflow was an anomalously high turbidity value estimated at 3,520 FNU (Bragg and others, 2007). This particularly large spike far exceeded any other measurement in the upper basin (fig. 14). The only other monitoring station to record a change in turbidity was Breitenbush, where two elevated but short-lived turbidity measurements of 86 and 76 FNU occurred 10 hours apart. In contrast to previously mentioned events, this major turbidity event had a higher magnitude, but shorter duration. In this case, the turbidity remained greater than 100 FNU for less than 17 hours, rather than for multiple days. Besides North Santiam and Breitenbush, none of the other monitoring stations displayed noticeable changes in turbidity.

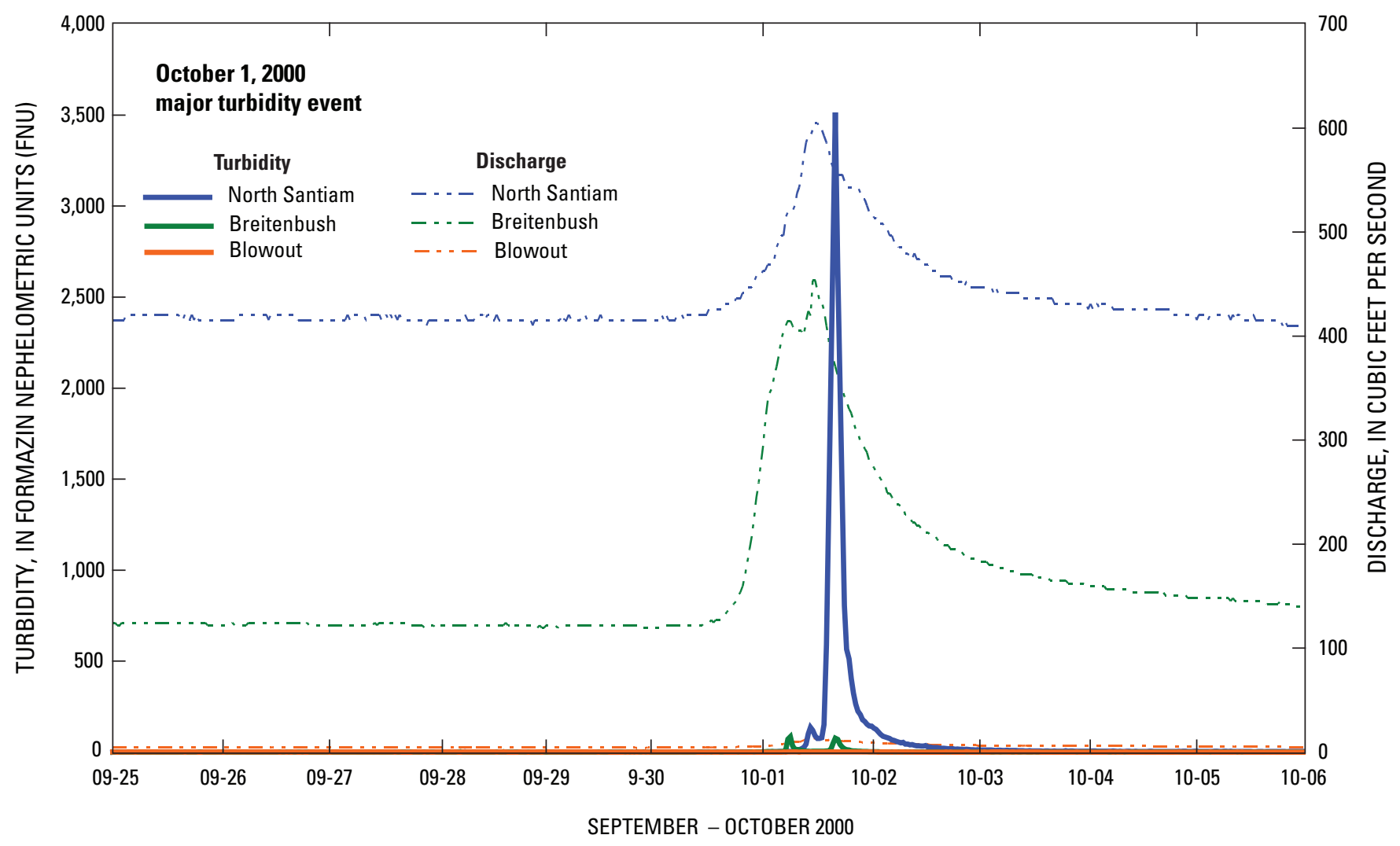

Figure 14. Turbidity and discharge at three upper basin monitoring stations for the 0ctober 1, 2000, major turbidity event in the North Santiam River basin, Oregon. 
Suspended-Sediment Loads and Clay-Water Volumes and Yields

On October 1, 2000, 1,580 tons of sediment passed the North Santiam monitoring station; far exceeding the amount measured at all other stations (table 6). Because water year 2001 was a drought year, this single-day upper North Santiam River high-turbidity event was responsible for 42 percent of the annual sediment load at that station. Although the amount of material transported during this event was less than that transported during the December 1998 and November 1999 storms, the unusual seasonality, source, and magnitude of this event was noteworthy. Because this event was isolated to the upper North Santiam subbasin, it was the only stream to contain clay-water on that day. The single-day event produced a volume of $287 \mathrm{Mgal}$, hundreds of millions of gallons less than the volume during events of precipitation-driven erosion in previous examples. The North Santiam River transported 79 percent of its annual clay-water volume during this single day, because drought conditions that year eliminated large winter storms. Clay-water volume at that station would very unlikely equal such a high percentage during normal climate conditions; previous event examples for this river had volumes in the thousands of millon gallons (4,710 and 8,850 Mgal, respectively). In addition, because this event occurred during low-flow conditions, material settled before being passed through Detroit Lake.

Table 6. Suspended-sediment load and yield, and clay-water volume and yield for the October 1, 2000, major turbidity event in the North Santiam River basin, Oregon.

[Abbreviations: ton $/ \mathrm{mi}^{2}$, tons per square mile; Mgal, million gallons; Mgal $/ \mathrm{mi}^{2}$, million gallons per square mile; N/A, no data available because station not yet established; <, less than]

\begin{tabular}{|c|c|c|c|c|c|c|}
\hline \multirow{2}{*}{$\begin{array}{l}\text { Station } \\
\text { name }\end{array}$} & \multicolumn{3}{|c|}{ Suspended sediment } & \multicolumn{3}{|c|}{ Clay-water } \\
\hline & $\begin{array}{l}\text { Load } \\
\text { (ton) }\end{array}$ & $\begin{array}{l}\text { Percentage of } \\
\text { annual load }\end{array}$ & $\begin{array}{c}\text { Yield } \\
\text { (ton/mi²) }\end{array}$ & $\begin{array}{l}\text { Volume } \\
\text { (Mgal) }\end{array}$ & $\begin{array}{l}\text { Percentage of } \\
\text { annual volume }\end{array}$ & $\begin{array}{c}\text { Yield } \\
\text { (Mgal/mi²) }\end{array}$ \\
\hline \multicolumn{7}{|c|}{ Upper basin stations } \\
\hline North Santiam & 1,580 & 42 & 7 & 287 & 79 & 1 \\
\hline Breitenbush & 37 & 6 & 0 & 0 & 0 & 0 \\
\hline French & N/A & N/A & N/A & N/A & N/A & N/A \\
\hline Blowout & 0 & $<1$ & $<0.1$ & 0 & 0 & 0 \\
\hline \multicolumn{7}{|c|}{ Lower basin station } \\
\hline Little North & 80 & 3 & 1 & 0 & 0 & 0 \\
\hline
\end{tabular}




\section{Sources of Turbidity}

At the time of the October 2000 major turbidity event, little was known about sediment sources in the upper North Santiam subbasin, except that the USFS observed extremely turbid water coming from Pamelia Creek as it entered the North Santiam River at Highway 22, near Marion Forks (fig. 15). Investigation of a later event (see "October 21, 2003-North Santiam River" section of this report) showed that turbidity in Pamelia Creek likely came from Milk Creek. Milk Creek flows from the Milk Creek Glacier on the western slopes of Mt. Jefferson (fig. 16). The Milk Creek watershed contains diverse environmental settings-some that are very stable with slight to moderate soil erosion potential and low silt or clay yield, and others that are only moderately stable, with severe erosion and moderate silt or clay yield (U.S. Forest Service, 1992). The watershed is mostly steep and contains basaltic and andesitic rocks with highly erodable glacial and glaciofluvial deposits of Pleistocene age (Walker and MacLeod, 1991). Land cover in the upper watershed is limited, as the landscape is mostly barren and glaciated, whereas shrubs and forests grow at lower altitudes (U.S. Geological Survey, 2005). The major turbidity event in October 2000 likely represented an episode of rapid melting in the area of the Milk Creek Glacier that carried glacial deposits downstream.

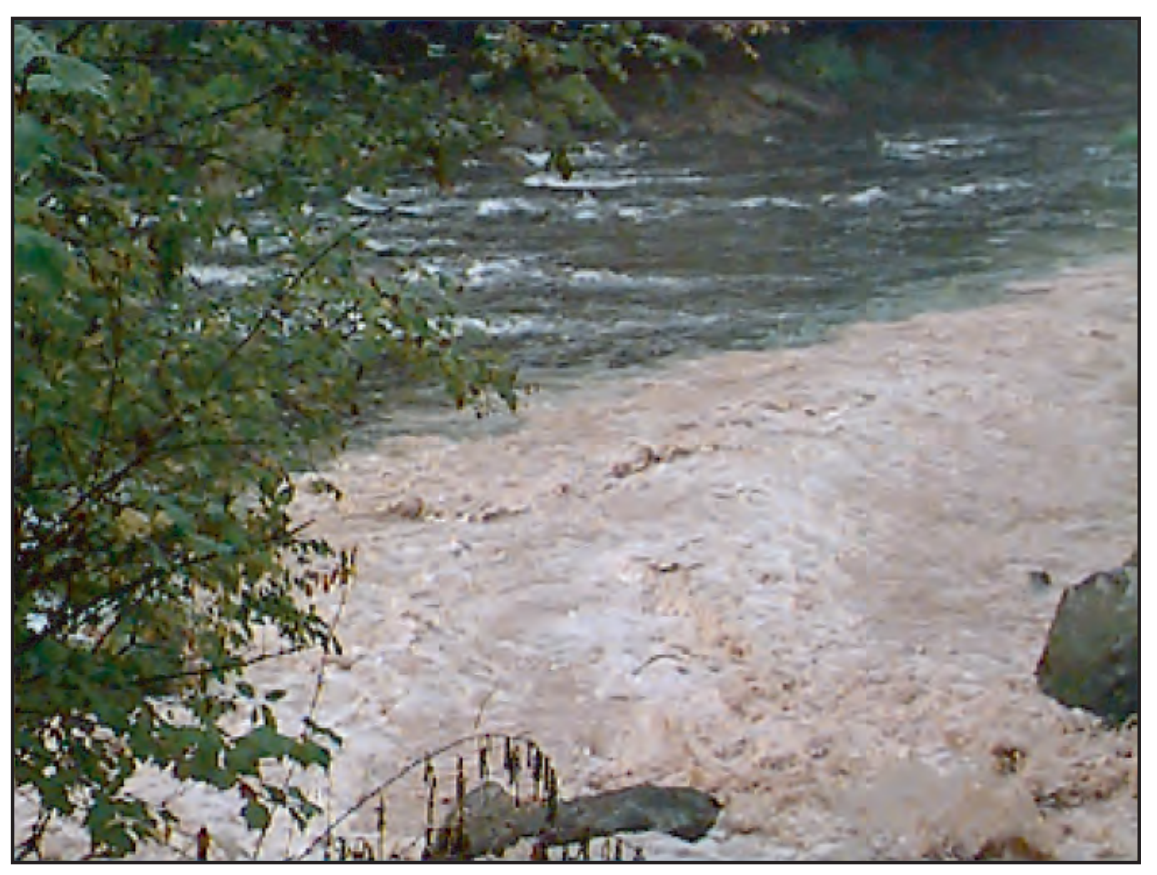

Figure 15. Turbid water flowing from Pamelia Creek into the North Santiam River, Oregon, in October 2000. (Photograph courtesy of U.S. Forest Service taken in 2000). 


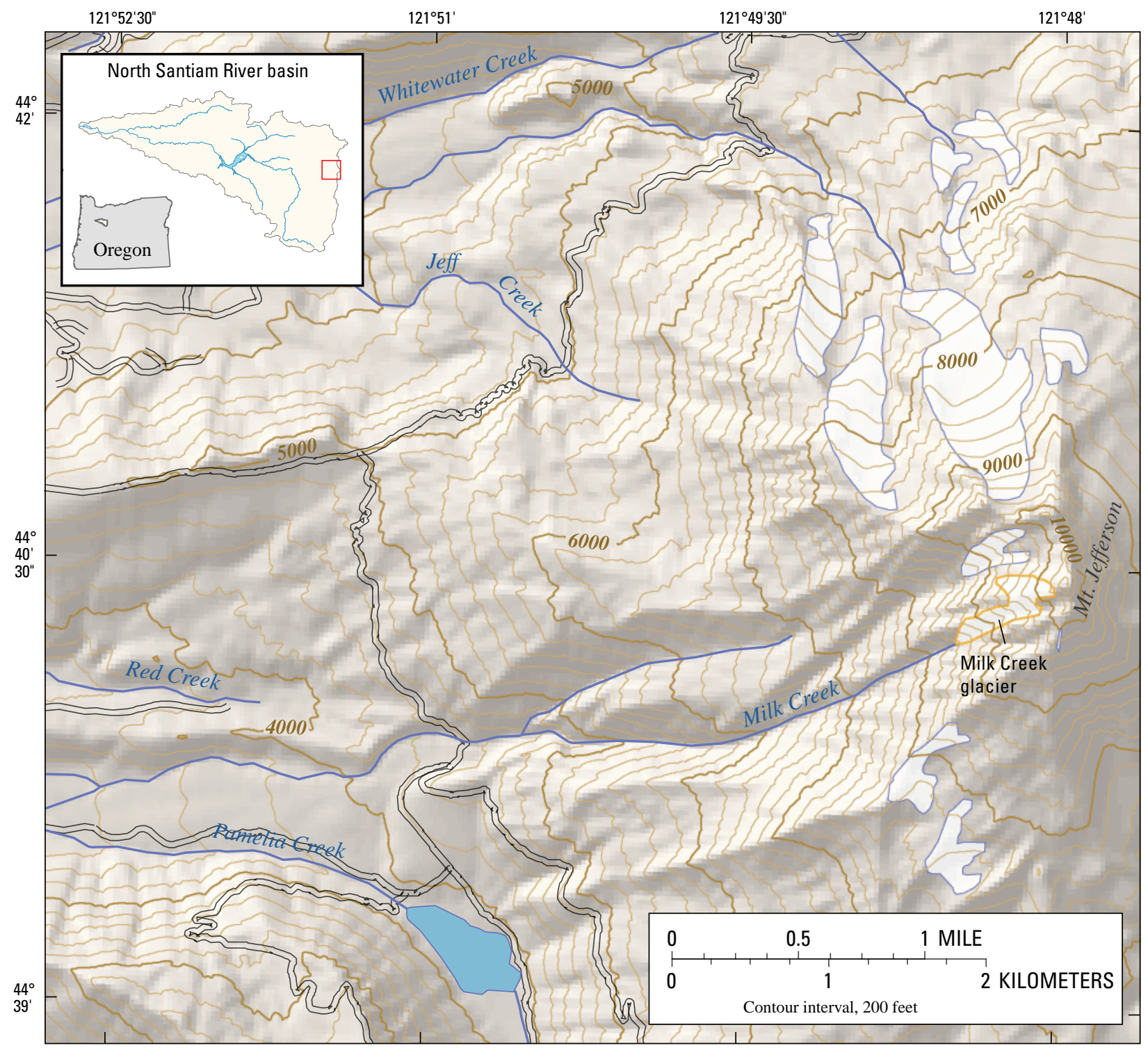

Base modified from USGS digital data, various scales, variously dated

Universe Transverse Mercator projection

Zone 10, North American Datum of 1927

Figure 16. Location of Milk Creek Glacier in the upper North Santiam basin, Oregon.

\section{Follow-Up Investigations}

In March 2003, an automatic pumping sampler was installed at the North Santiam monitoring station. The pumping sampler was programmed to collect $1-\mathrm{L}$ samples every 120 minutes when instream turbidity values exceeded a predetermined threshold (for example, greater than $20 \mathrm{FNU}$ ). This approach allowed for more timely samples than could be collected by field personnel. In addition, during the last
5 years, field investigations have attempted to locate potential sediment sources that supply material to Pamelia and Milk Creeks. For example, sediment samples from a variety of Cascadian sources from the upper watershed have been collected, with the aim of determining connections between specific source areas and suspended sediment collected in water-quality samples. 


\section{December 17-19, 2001—Blowout Creek}

\section{Conditions}

Starting in late November and extending into early December 2001, rain fell almost daily on the North Santiam River basin. According the USGS rain gage at Blowout Creek, a local storm cell during December 13-14 produced nearly 4 in. of rain. Two days later, a new weather front delivered an additional 1-2 in. of rain, followed by a third storm on the morning of December 17 that added a final 1-2 in. of rain. During those last few weeks of 2001, 25 in. of rain fell on the upper basin, with more than $10 \mathrm{in}$. during just 8 days (Oregon Climate Service, 2006). The heavy rains increased streamflow at the North Santiam monitoring station to $4,120 \mathrm{ft}^{3} / \mathrm{s}$, whereas at the Breitenbush, and Blowout, and French monitoring stations, streamflow reached $2,870 \mathrm{ft}^{3} / \mathrm{s}, 1,180 \mathrm{ft}^{3} / \mathrm{s}$, and $565 \mathrm{ft}^{3} / \mathrm{s}$, respectively (fig. 17). In the lower basin, streamflow at the Little North monitoring station reached $9,930 \mathrm{ft}^{3} / \mathrm{s}$. Instantaneous turbidity records (ig. 17) from the water-quality network during mid-December showed turbidity spikes greater than $20 \mathrm{FNU}$ at the upper-basin monitoring stations-North Santiam at 22 FNU, French at 43 FNU, Breitenbush at $37 \mathrm{FNU}$, and Blowout estimated at 3,400 FNU (Bragg and others, 2007). Turbidity levels were much lower downstream of Detroit Lake (12 FNU on the North Santiam River at Niagara) but increased downstream (at Mehama and Geren Island, 55 and $30 \mathrm{FNU}$, respectively) because of input from tributaries like the Little North Santiam River (55 FNU).

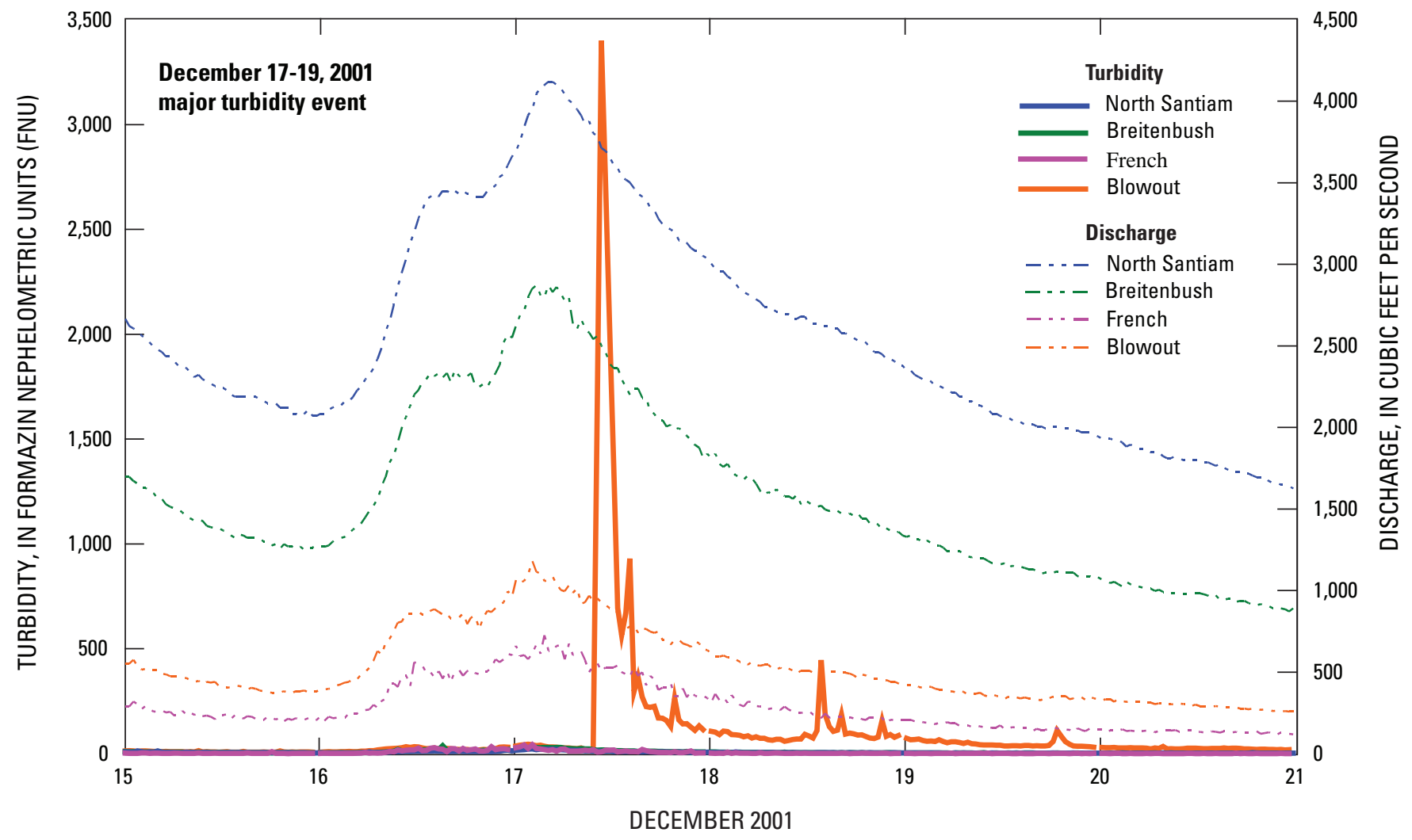

Figure 17. Turbidity and discharge at four upper basin monitoring stations for the December 17-19, 2001, major turbidity event in the North Santiam River basin, Oregon. 
Suspended-Sediment Loads and Clay-Water Volumes and Yields

By mid-December, consistent rain eroded surfaces and mobilized landslides, causing turbidity to increase at each station. Associated with the elevated turbidity was an increased sediment load for each location (table 7). The largest suspended-sediment load during the storm was an estimated 4,900 tons transported past the Blowout monitoring station, which was the third largest event load for Blowout Creek during the study period. The Blowout Creek subbasin was the only subbasin to transport a large suspended-sediment load, about 36 percent of the annual load, a yield of 190 tons $/ \mathrm{mi}^{2}$. Similarly, Blowout Creek was the only stream to transport clay-water. Over the 3-day period, $522 \mathrm{Mgal}$ of clay-water issued from Blowout Creek into Detroit Lake, a yield of $20 \mathrm{Mgal} / \mathrm{mi}^{2}$. That was about 17 percent of the total annual clay-water volume for the subbasin that year. Clay yield in the December 2001 event was considerably less than clay yield during previous Blowout Creek events because the source this time was a landslide rather than the earthflows.

Table 7. Suspended-sediment load and yield, and clay-water volume and yield for the December 17-19, 2001, major turbidity event in the North Santiam River basin, Oregon.

[Abbreviations: ton $/ \mathrm{mi}^{2}$, ton per square mile; Mgal, million gallons; $\mathrm{Mgal} / \mathrm{mi}^{2}$, million gallons per square mile; N/A, no data available because station not yet established; <, less than]

\begin{tabular}{|c|c|c|c|c|c|c|}
\hline \multirow{2}{*}{$\begin{array}{l}\text { Station } \\
\text { name }\end{array}$} & \multicolumn{3}{|c|}{ Suspended sediment } & \multicolumn{3}{|c|}{ Clay-water } \\
\hline & $\begin{array}{l}\text { Load } \\
\text { (ton) }\end{array}$ & $\begin{array}{l}\text { Percentage of } \\
\text { annual load }\end{array}$ & $\begin{array}{c}\text { Yield } \\
\text { (ton/mi²) }\end{array}$ & $\begin{array}{c}\text { Volume } \\
\text { (Mgal) }\end{array}$ & $\begin{array}{l}\text { Percentage of } \\
\text { annual volume }\end{array}$ & $\begin{array}{c}\text { Yield } \\
\left(\mathrm{Mgal}^{2} \mathrm{mi}^{2}\right)\end{array}$ \\
\hline \multicolumn{7}{|c|}{ Upper basin stations } \\
\hline North Santiam & 333 & 2 & 2 & 0 & 0 & 0 \\
\hline Breitenbush & 333 & 2 & 3 & 0 & 0 & 0 \\
\hline French & 22 & 2.8 & 2.2 & 0 & 0 & 0 \\
\hline Blowout & 4,900 & 36 & 190 & 522 & 17 & 20 \\
\hline \multicolumn{7}{|c|}{ Lower basin station } \\
\hline Little North & 419 & 2 & 4 & 0 & 0 & 0 \\
\hline
\end{tabular}




\section{Sources of Turbidity}

Sampling during the storm revealed that the high turbidity in Blowout Creek originated from Ivy Creek, an upstream tributary. The muddy water was traced back to a landslide and associated road failure along Forest Road 1012, which released material down an unnamed channel into Ivy
Creek (fig. 18). The damage to Forest Road 1012, including the exposed scarp and road-grade deformation, is shown in figure 19. Based on calculations for a half-ellipsoid-shaped landslide (Cruden and Varnes, 1996), an estimated $178 \mathrm{yd}^{3}$ of material slipped from the roadbed. On the basis of fluvialsediment discharge computations (Porterfield, 1972), roughly

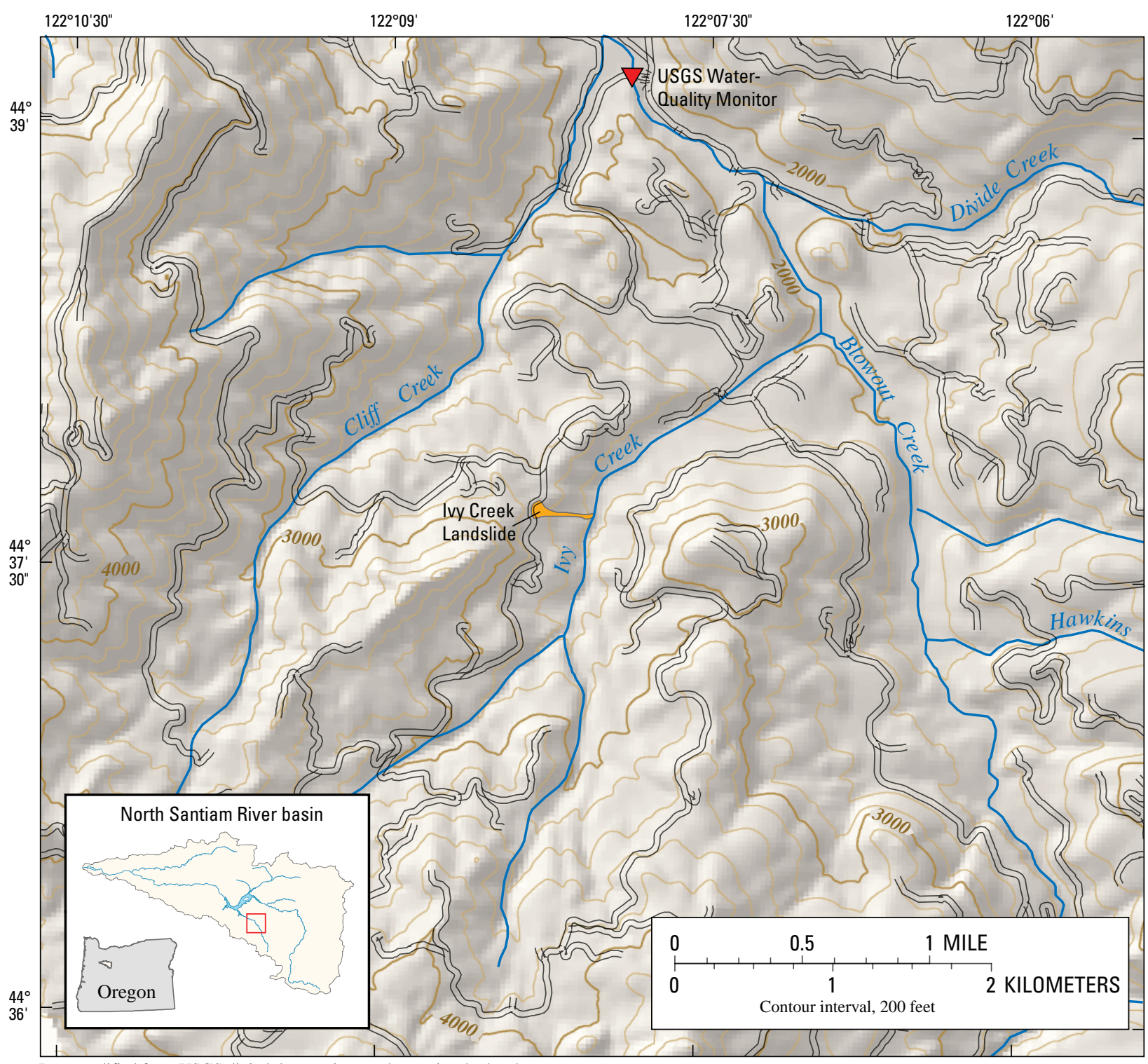

Base modified from USGS digital data, various scales, variously dated

Universe Transverse Mercator projection

Zone 10, North American Datum of 1927

Figure 18. Location of Ivy Creek landslide in the Blowout Creek subbasin of the North Santiam River basin, Oregon. 


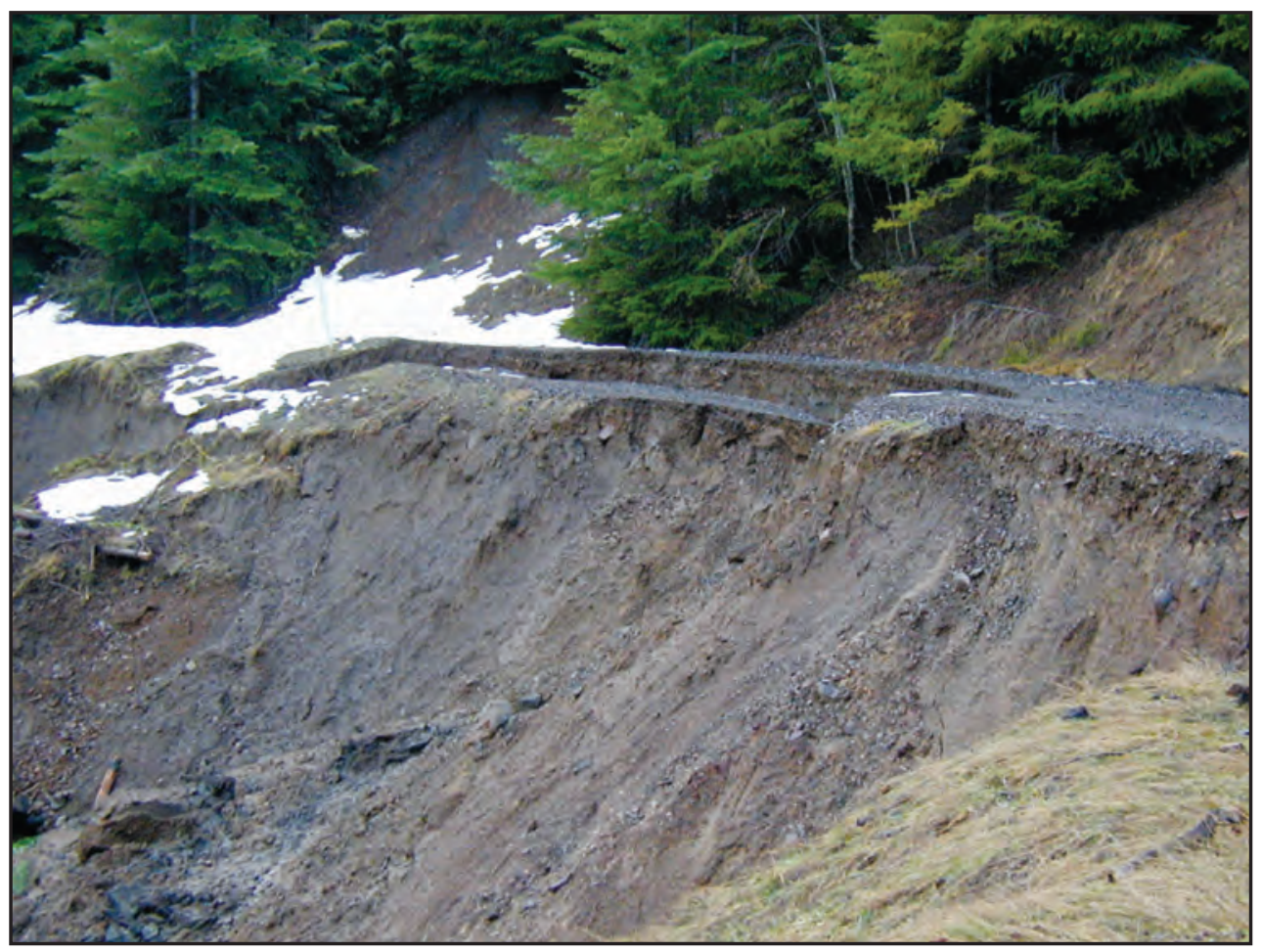

Figure 19. Ivy Creek landslide and subsequent road failure of Forest Road 1012 in the Blowout Creek subbasin of the North Santiam River basin, Oregon. (Photograph by U.S. Geological Survey, taken in 2001).

377 tons of saturated soil and debris was mobilized and lost from the road failure. As the saturated material traveled downhill, it created a debris flow, gaining considerably more mass as material was eroded from the 1,300-ft channel before entering the stream (fig. 20). After the sediment and debris entered Ivy Creek, it continued downstream into Blowout
Creek, eventually passing the USGS water-quality monitor. Because the water in Blowout Creek was clear upstream of the turbid Ivy Creek confluence, most of the turbidity registered at the Blowout monitoring station came from this landslide and associated debris flow. 


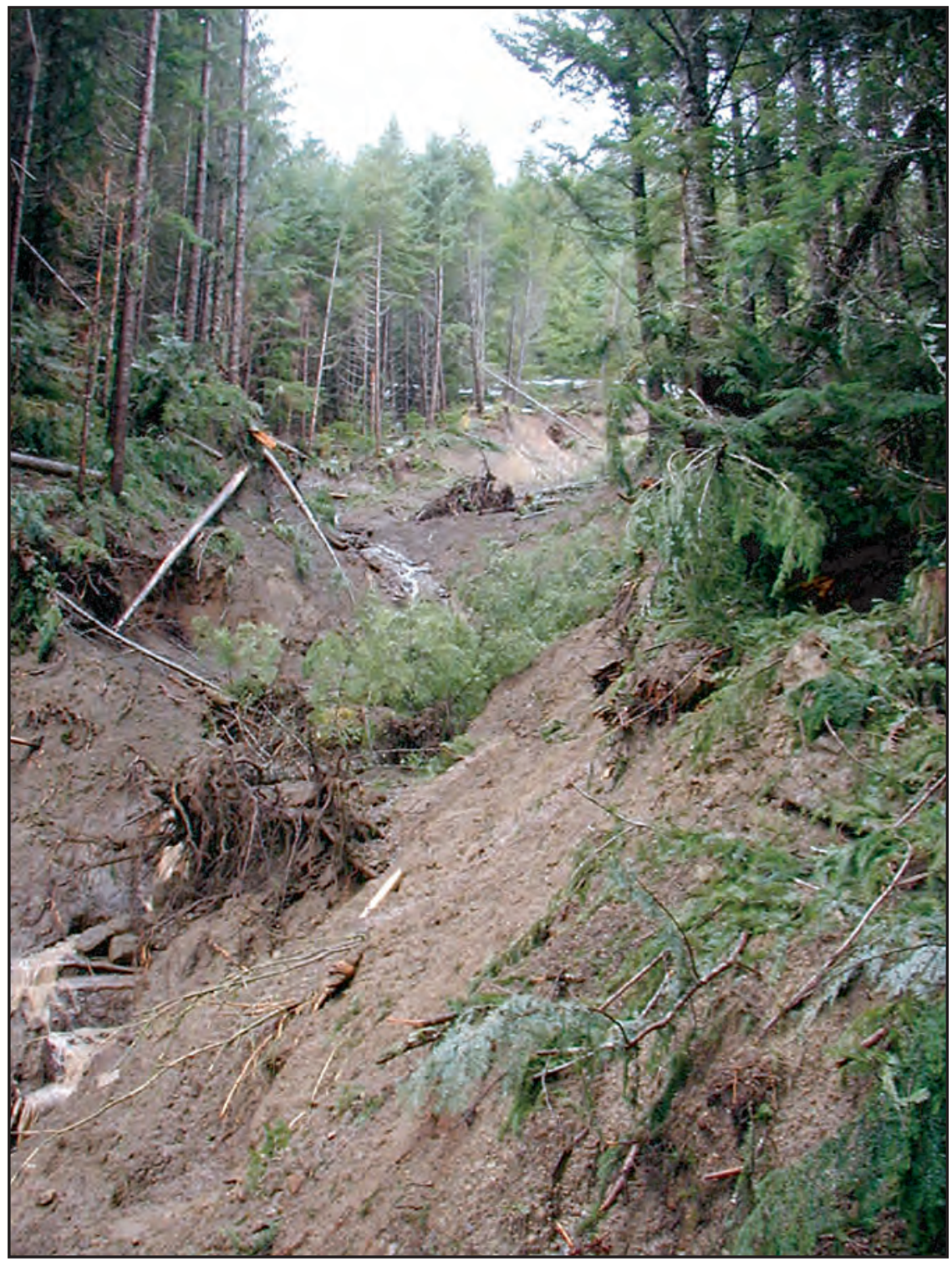

Figure 20. Debris flow scar resulting from Ivy Creek landslide in the Blowout Creek subbasin of the North Santiam River basin, Oregon. (Photograph by U.S. Geological Survey, taken in 2001). 


\section{Follow-Up Investigations}

In general, slopes in the Ivy Creek drainage basin are stable, with moderate soil erosion and runoff potential (U.S. Forest Service, 1992). The sedimentary and volcaniclastic geology (Walker and MacLeod, 1991) and dense evergreen land cover (U.S. Geological Survey, 2005) also help stabilize the area. However, intense and prolonged rainfall in 2001 weakened the surface and caused sliding. Since 2001, the road-failure location has been surveyed multiple times to estimate feature size and sediment displacement. Following the original failure, subsequent movement has widened the scarp (fig. 21). Recently, this section of Forest Road 1012 was decommissioned and then obliterated, and the fill material was removed (David Klug, U.S. Forest Service, written commun., 2006).

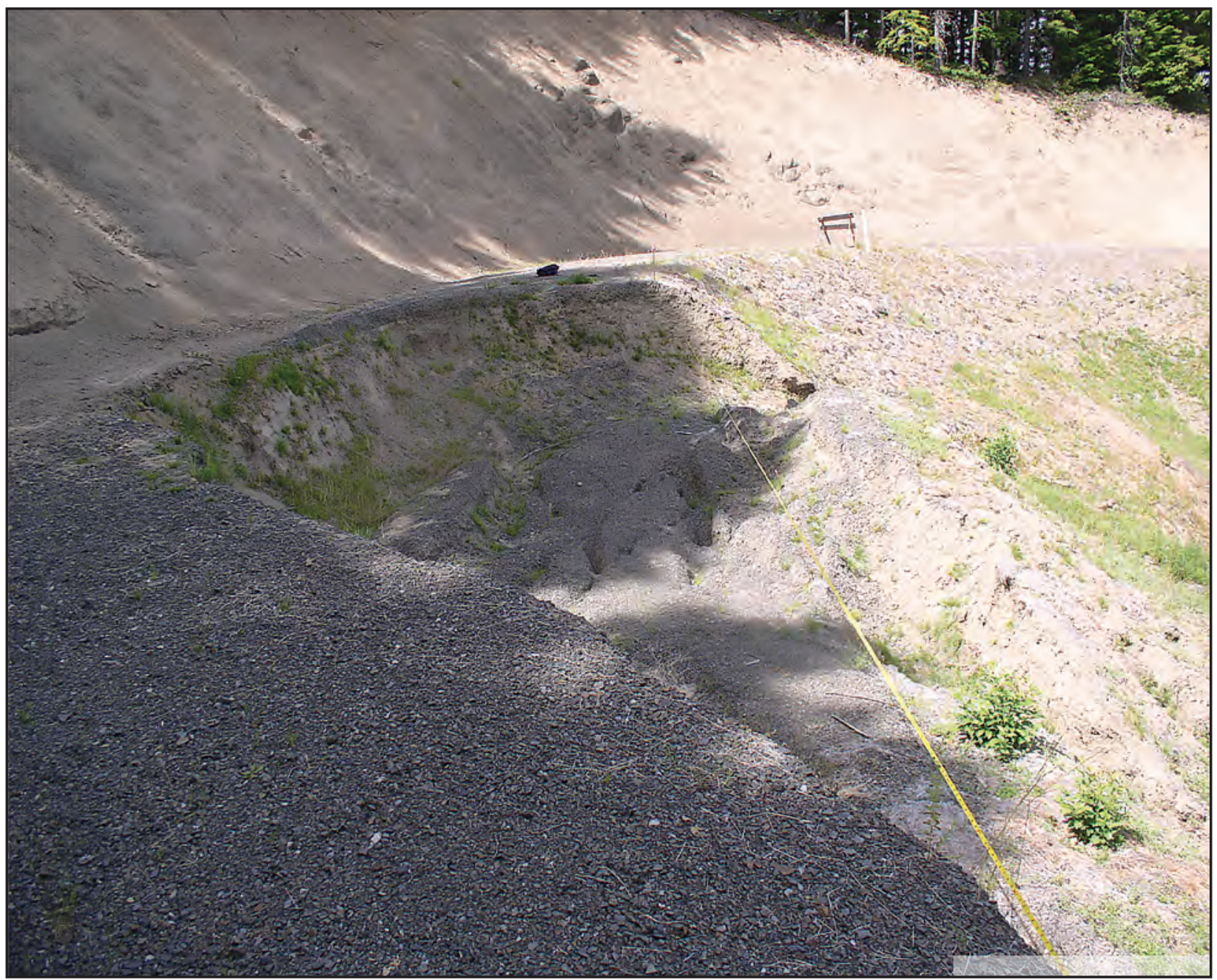

Figure 21. Enlarged scarp from the lvy Creek landslide along decommissioned Forest Road 1012 in the Blowout Creek subbasin of the North Santiam River basin, Oregon. (Photograph by U.S. Geological Survey, taken in 2006). 


\section{January 30-February 1, 2003-French Creek}

\section{Conditions}

From January 29 to February 2, 2003, as much as 3 to 5 in. of rain fell on the North Santiam River basin, depending on locality, according to measurements at Detroit Dam (Oregon Climate Service, 2006) and the USGS Blowout Creek rain gage. The heavy rainfall increased streamflow at the North Santiam monitoring station to $6,670 \mathrm{ft}^{3} / \mathrm{s}$, Breitenbush to $5,270 \mathrm{ft}^{3} / \mathrm{s}$, French to $1,470 \mathrm{ft}^{3} / \mathrm{s}$, and Blowout to $1,240 \mathrm{ft}^{3} / \mathrm{s}$. In the lower basin, streamflow increased at the Little North monitoring station to $9,900 \mathrm{ft}^{3} / \mathrm{s}$. In correspondence with the increased streamflow, turbidity at the North Santiam monitoring station reached 86 FNU, Breitenbush reached $162 \mathrm{FNU}$, and Blowout reached $74 \mathrm{FNU}$ (fig. 22). On January 31 at 06:30 a.m., the water-quality monitor at French Creek recorded the highest turbidity value of any station, a spike of 1,530 FNU. The turbidity probably rose higher, but because of the sudden onset and short duration of the event, along with the instrument reaching its maximum measurement capacity, the actual peak is unknown. Downstream of Detroit Dam, turbidity was high along the lower North Santiam River, with values reaching 16 FNU at Niagara, 98 FNU at Mehama, and 93 FNU at Geren Island. The Little North Santiam River also was turbid, reaching 133 FNU.

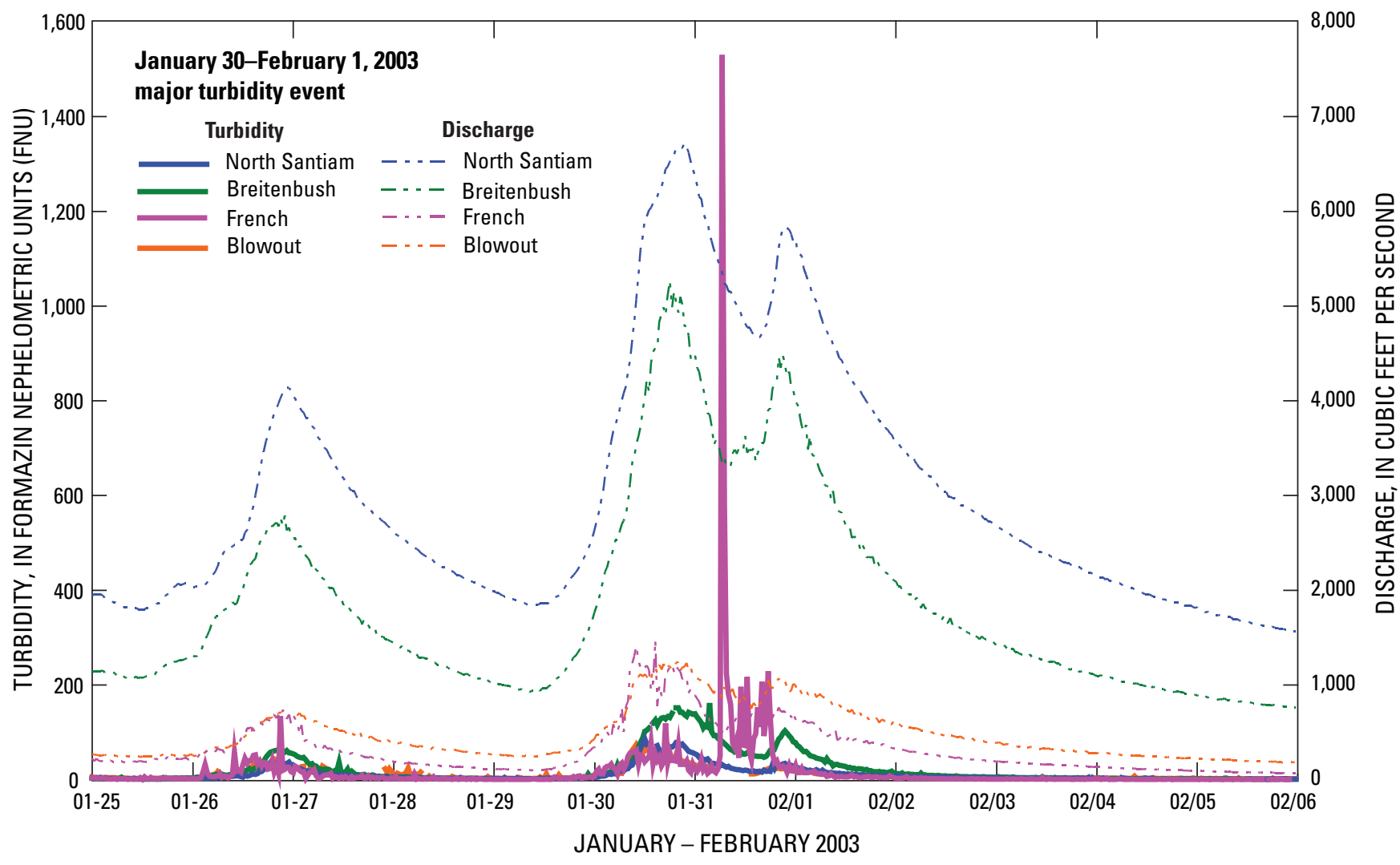

Figure 22. Turbidity and discharge at four upper basin monitoring stations for the January 30-February 1, 2003, major turbidity event in the North Santiam River basin, Oregon. 
Suspended-Sediment Loads and Clay-Water Volumes and Yields

During the January-February storm, suspended-sediment loads increased at all locations in the basin (table 8). The most noticeable increased load was in French Creek, where values typically had been low. Now, for the first time since its installation in 2001, the water-quality monitor recorded a major turbidity event, with a corresponding event sediment load of 400 tons ( 40 tons $/ \mathrm{mi}^{2}$ ). In comparison with other upper basin streams, French Creek transported the smallest total load, but the second largest percentage of annual load (60 percent) behind Breitenbush (63 percent). This event marked the largest suspended-sediment load and percentage of annual load for French Creek during the study. In addition, the January-February 2003 major turbidity event was the only event during the study to produce clay-water in French Creek (67 Mgal). Because the French Creek subbasin is small $\left(10 \mathrm{mi}^{2}\right)$ with coarse, immature soils (U.S. Forest Service, 1992), clay-water volume for most of the other stations was expectedly higher, although absent at Blowout Creek (table 8).

Table 8. Suspended-sediment load and yield, and clay-water volume and yield for the January 30 February 1, 2003, major turbidity event in the North Santiam River basin, Oregon.

[Abbreviations: ton $/ \mathrm{mi}^{2}$, ton per square mile; Mgal, million gallons; $\mathrm{Mgal} / \mathrm{mi}^{2}$, million gallons per square mile; N/A, no data available because station not yet established; <, less than]

\begin{tabular}{|c|c|c|c|c|c|c|}
\hline \multirow{2}{*}{$\begin{array}{l}\text { Station } \\
\text { name }\end{array}$} & \multicolumn{3}{|c|}{ Suspended sediment } & \multicolumn{3}{|c|}{ Clay-water } \\
\hline & $\begin{array}{l}\text { Load } \\
\text { (ton) }\end{array}$ & $\begin{array}{l}\text { Percentage of } \\
\text { annual load }\end{array}$ & $\begin{array}{c}\text { Yield } \\
(\text { ton/mi²) }\end{array}$ & $\begin{array}{l}\text { Volume } \\
\text { (Mgal) }\end{array}$ & $\begin{array}{l}\text { Percentage of } \\
\text { annual volume }\end{array}$ & $\begin{array}{c}\text { Yield } \\
\left({\left.\mathrm{Mgal} / \mathrm{mi}^{2}\right)}^{2}\right.\end{array}$ \\
\hline \multicolumn{7}{|c|}{ Upper basin stations } \\
\hline North Santiam & 2,710 & 40 & 12 & 1,700 & 98 & 8 \\
\hline Breitenbush & 5,350 & 63 & 50 & 2,420 & 100 & 22 \\
\hline French & 400 & 60 & 40 & 67 & 100 & 6.7 \\
\hline Blowout & 471 & 24 & 18 & 0 & 0 & 0 \\
\hline \multicolumn{7}{|c|}{ Lower basin station } \\
\hline Little North & 6,160 & 44 & 55 & 5,910 & 84 & 53 \\
\hline
\end{tabular}




\section{Sources of Turbidity}

With most monitors reading turbidity at equal to or less than $100 \mathrm{FNU}$, effort for field verification was spent looking for the source of the major turbidity event in French Creek. On January 31, USGS scientists visited French Creek and observed that a debris flow had crossed French Creek and French Creek Road less than 0.5 mi upstream of the monitoring station (fig. 23). Large cobbles, boulders, and debris littered the road (fig. 24). The area around the debris flow was naturally stable, although susceptible to severe soil erosion and runoff (U.S. Forest Service, 1992). No calculations were made to estimate the size or volume of material displaced by the debris flow; however, most of the suspended-sediment load in French Creek originated from this source.

\section{Follow-Up Investigations}

Because of the rarity of such high-turbidity events, and the difficulty in maintaining active telemetry in the heavily forested French Creek subbasin, the station was decommissioned in 2005.

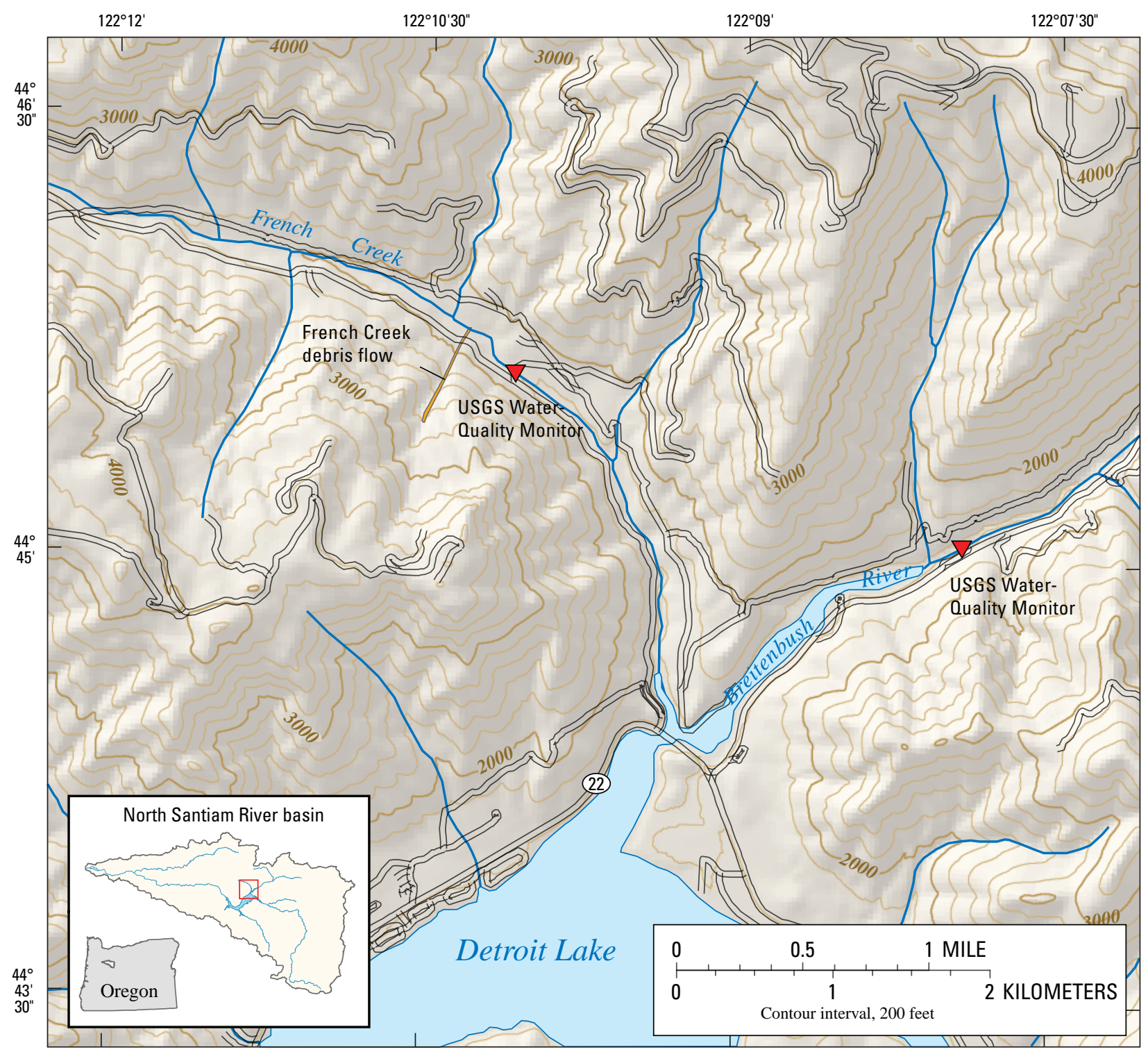

Base modified from USGS digital data, various scales, variously dated Universe Transverse Mercator projection Zone 10, North American Datum of 1927

Figure 23. Location of French Creek debris flow in the French Creek subbasin of the North Santiam River basin, Oregon. 


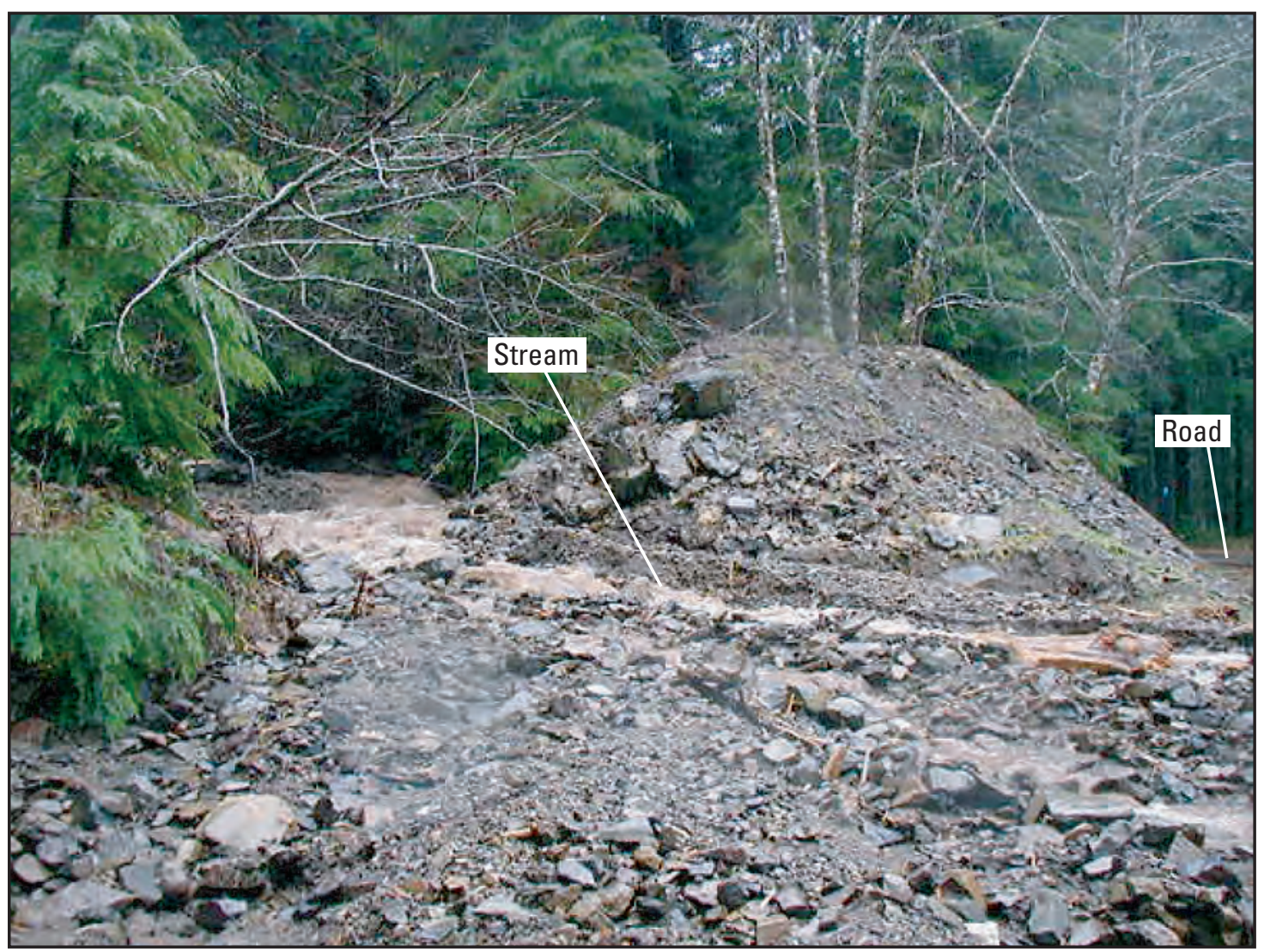

Figure 24. Debris flow in French Creek subbasin of the North Santiam River basin. (Photograph by U.S. Geological Survey, taken in 2003). 


\section{October 21, 2003 - North Santiam River}

\section{Conditions}

A second major turbidity event, similar to that of October 2000, occurred in the North Santiam subbasin in October 2003. Once again, in late September and early October 2003, record-setting high temperatures were recorded in the basin. Temperatures rose to $88^{\circ} \mathrm{F}$ on September 29 , and daily high temperatures remained in the upper 70s for most of October (Oregon Climate Service, 2006). The warm temperatures increased snow and glacial melt and slightly increased runoff in upper-basin streams. On October 21, an extraordinarily large spike in turbidity estimated at 5,550 FNU exceeded sensor measurements at the North Santiam monitoring station (Bragg and others, 2007). The high turbidity was relatively short-lived, remaining greater than 100 NTU for just more than 14 hours before decreasing to less than 10 FNU. The North Santiam monitoring station was the only one of the upper-basin monitor stations to record high turbidity (fig. 25). The high turbidity estimate was verified by a series of water samples collected by the newly installed automatic pumping sampler, which was triggered during the event (fig. 26). Although no rain fell during the actual turbidity event, nearly 3 in. of rain had fallen in the High Cascades during the weeks leading up to the October 21 event (Oregon Climate Service, 2006).

\section{Suspended-Sediment Loads and Clay-Water} Volumes and Yields

The total suspended-sediment load transported during this major turbidity event was 2,030 tons (table 9). This event load was about 25 percent larger than the previous glacialoutwash event in October 2000, yet accounted for less of the annual load at 27 percent because of more winter rainfall. The clay-water volume for the event was $222 \mathrm{Mgal}$, representing 12 percent of the annual clay-water volume. This was much less significant than the 79 percent of annual clay-water volume for the October 2000 event.

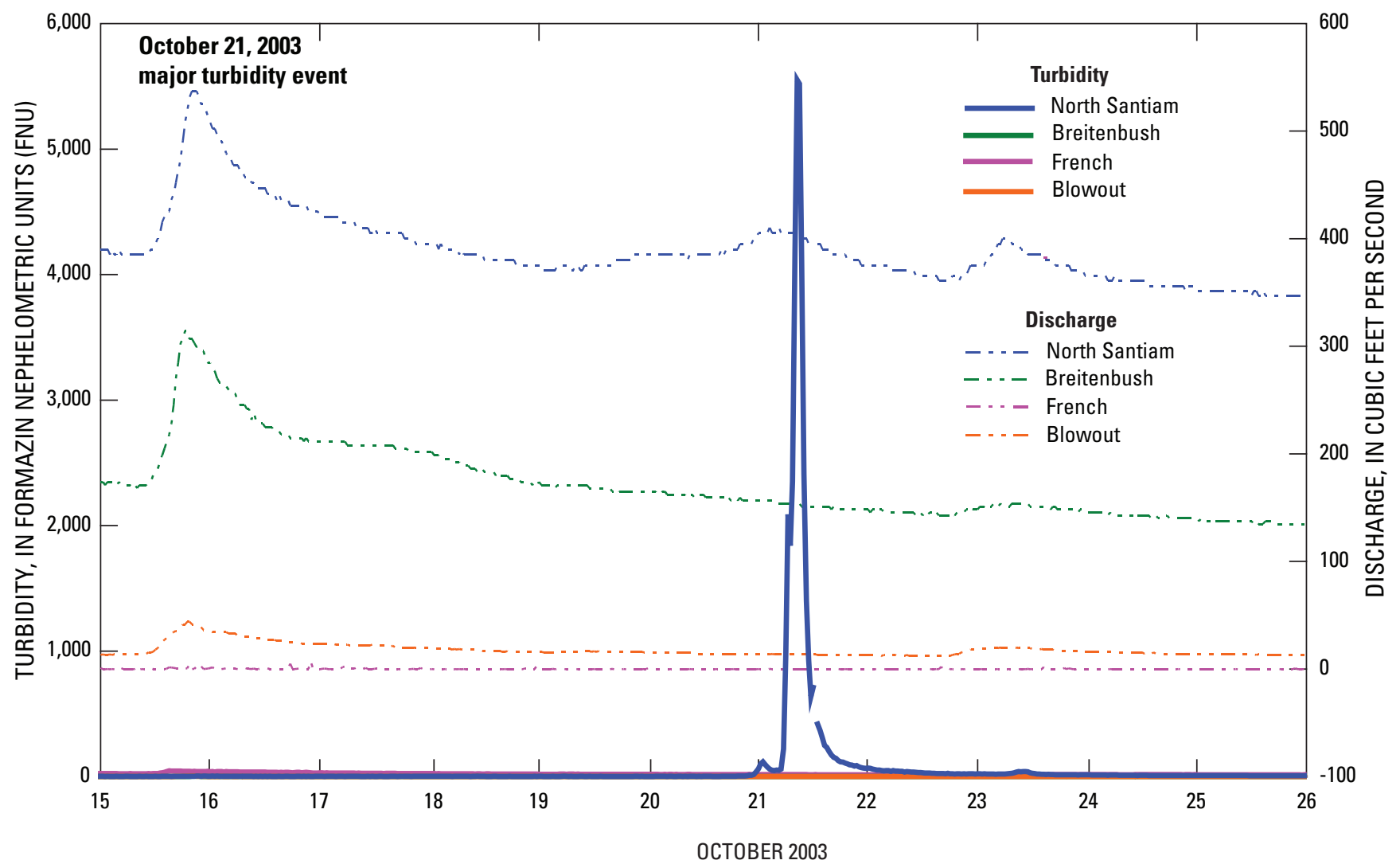

Figure 25. Turbidity and discharge at four upper basin monitoring stations for the 0ctober 21, 2003, major turbidity event in the upper North Santiam River basin, Oregon. 


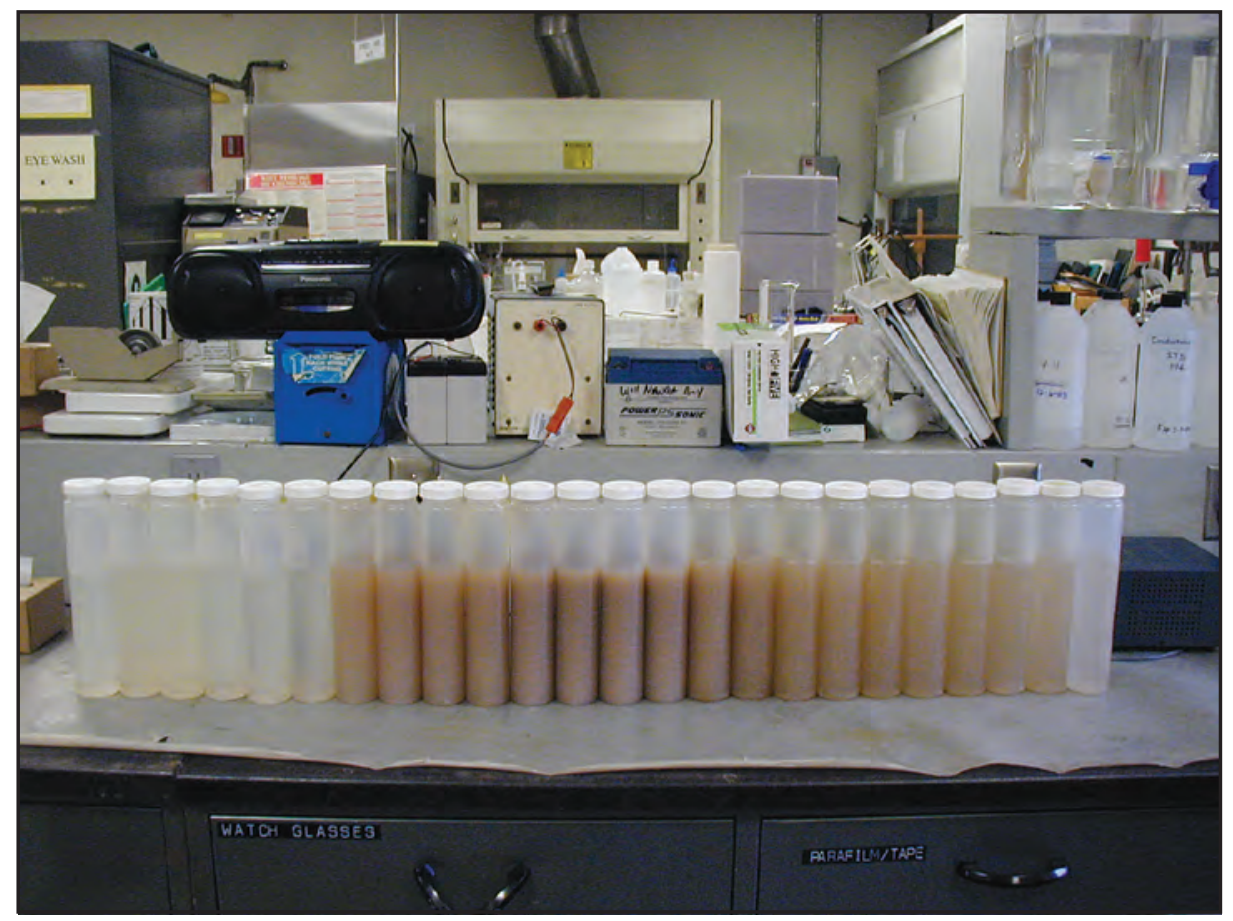

Figure 26. Automatic pumping samples collected during the October 21, 2003, major turbidity event in the upper North Santiam River basin, Oregon. (Photograph by U.S. Geological Survey, taken in 2003).

Table 9. Suspended-sediment load and yield, and clay-water volume and yield for the 0ctober 21, 2003, major turbidity event in the North Santiam River basin, Oregon.

[Abbreviations: ton $/ \mathrm{mi}^{2}$, ton per square mile; $\mathrm{Mgal}$, million gallons; $\mathrm{Mgal} / \mathrm{mi}^{2}$, million gallons per square mile]

\begin{tabular}{|c|c|c|c|c|c|c|}
\hline \multirow{2}{*}{$\begin{array}{l}\text { Station } \\
\text { name }\end{array}$} & \multicolumn{3}{|c|}{ Suspended sediment } & \multicolumn{3}{|c|}{ Clay-water } \\
\hline & $\begin{array}{l}\text { Load } \\
\text { (ton) }\end{array}$ & $\begin{array}{l}\text { Percentage of } \\
\text { annual load }\end{array}$ & $\begin{array}{c}\text { Yield } \\
\text { (ton/mi²) }\end{array}$ & $\begin{array}{c}\text { Volume } \\
\text { (Mgal) }\end{array}$ & $\begin{array}{l}\text { Percentage of } \\
\text { annual volume }\end{array}$ & $\begin{array}{c}\text { Yield } \\
\left({\left.\mathrm{Mgal} / \mathrm{mi}^{2}\right)}^{2}\right.\end{array}$ \\
\hline \multicolumn{7}{|c|}{ Upper basin stations } \\
\hline North Santiam & 2,030 & 27 & 9 & 222 & 12 & 1 \\
\hline Breitenbush & 0 & 0 & 0 & 0 & 0 & 0 \\
\hline French & 0 & 0 & 0 & 0 & 0 & 0 \\
\hline Blowout & 0 & 0 & 0 & 0 & 0 & 0 \\
\hline \multicolumn{7}{|c|}{ Lower basin station } \\
\hline Little North & 0 & 0 & 0 & 0 & 0 & 0 \\
\hline
\end{tabular}




\section{Sources of Turbidity}

Sediment responsible for the elevated turbidity in the upper North Santiam River came from upstream in the Milk Creek by way of Pamelia Creek (fig. 27), as in October 2000.

\section{Follow-Up Investigations}

As mentioned earlier (see section, "October 1, 2000North Santiam River: Follow-Up Investigations"), field investigations during the last 5 years have attempted to locate potential sources for future events from Milk Creek and the Milk Creek Glacier. As a result of high temperatures, snowmelt, and glacial outwash likely eroded exposed glacial sediments (fig. 28) or landslide material (fig. 29) and transported it downstream.

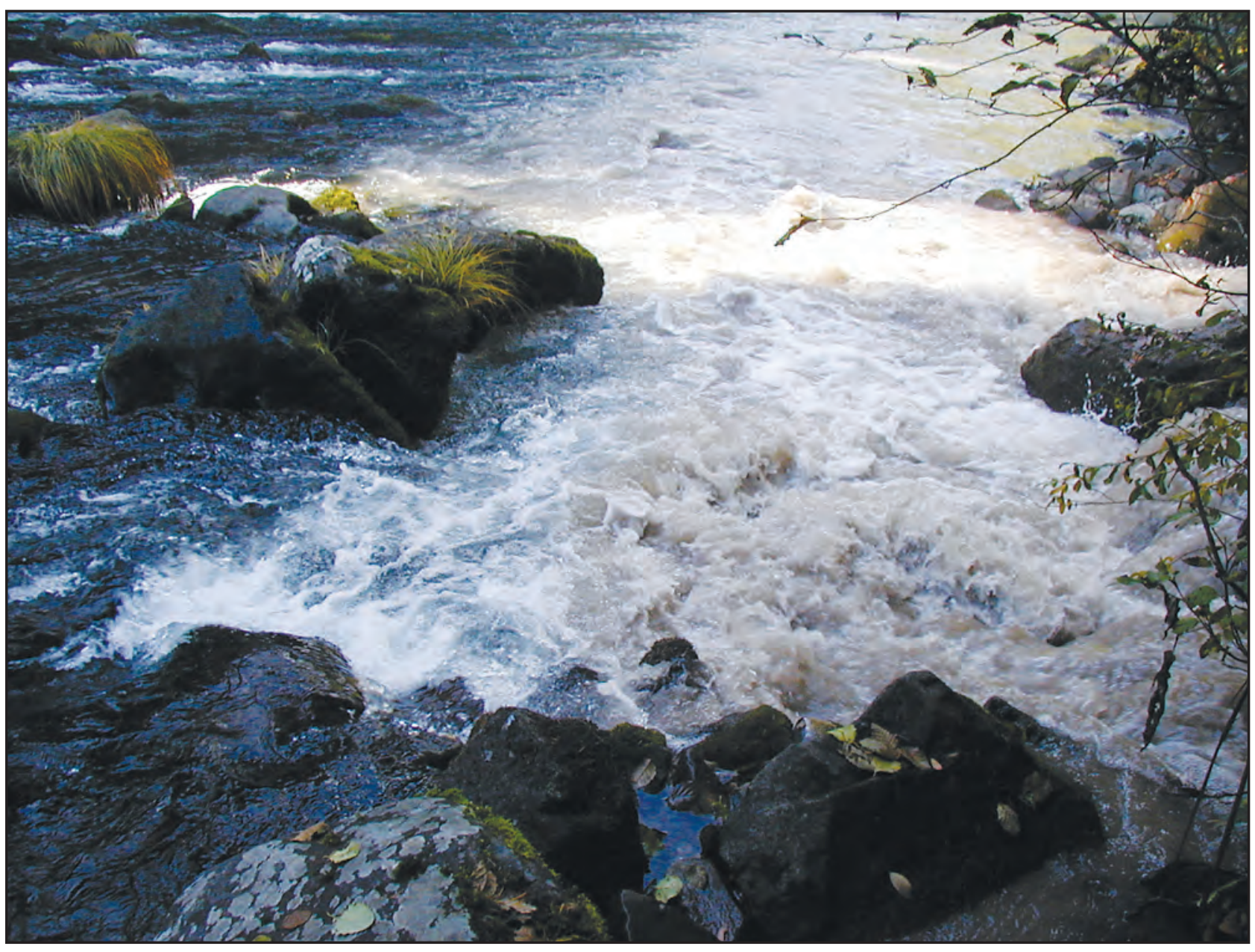

Figure 27. Turbid water flowing from Pamelia Creek into the North Santiam River, Oregon, in October 2003. (Photograph by U.S. Geological Survey, taken in 2003). 


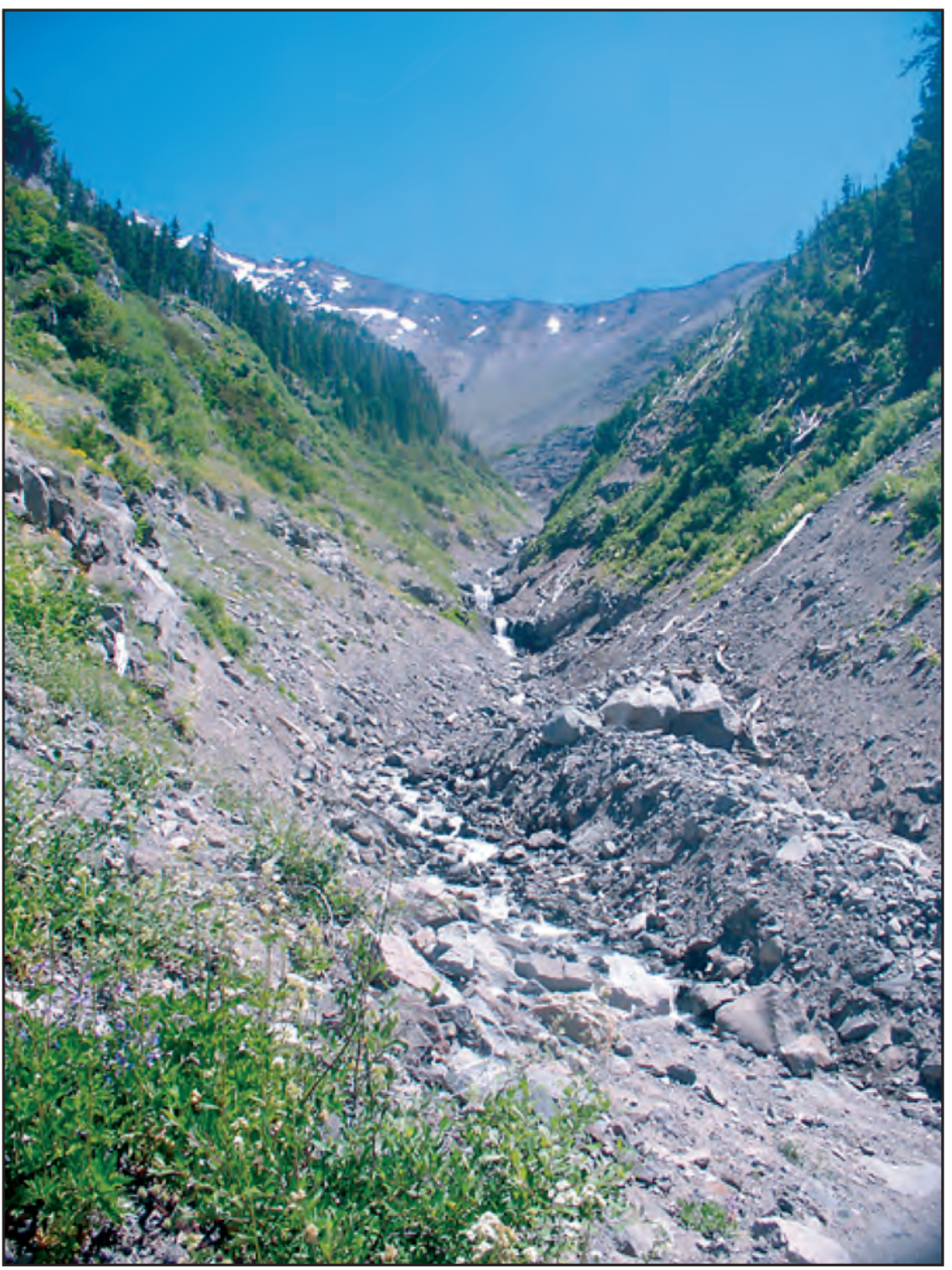

Figure 28. Glaciofluvial and moraine deposits in the upper North Santiam River basin, Oregon. (Photograph by U.S. Geological Survey, taken in 2005). 


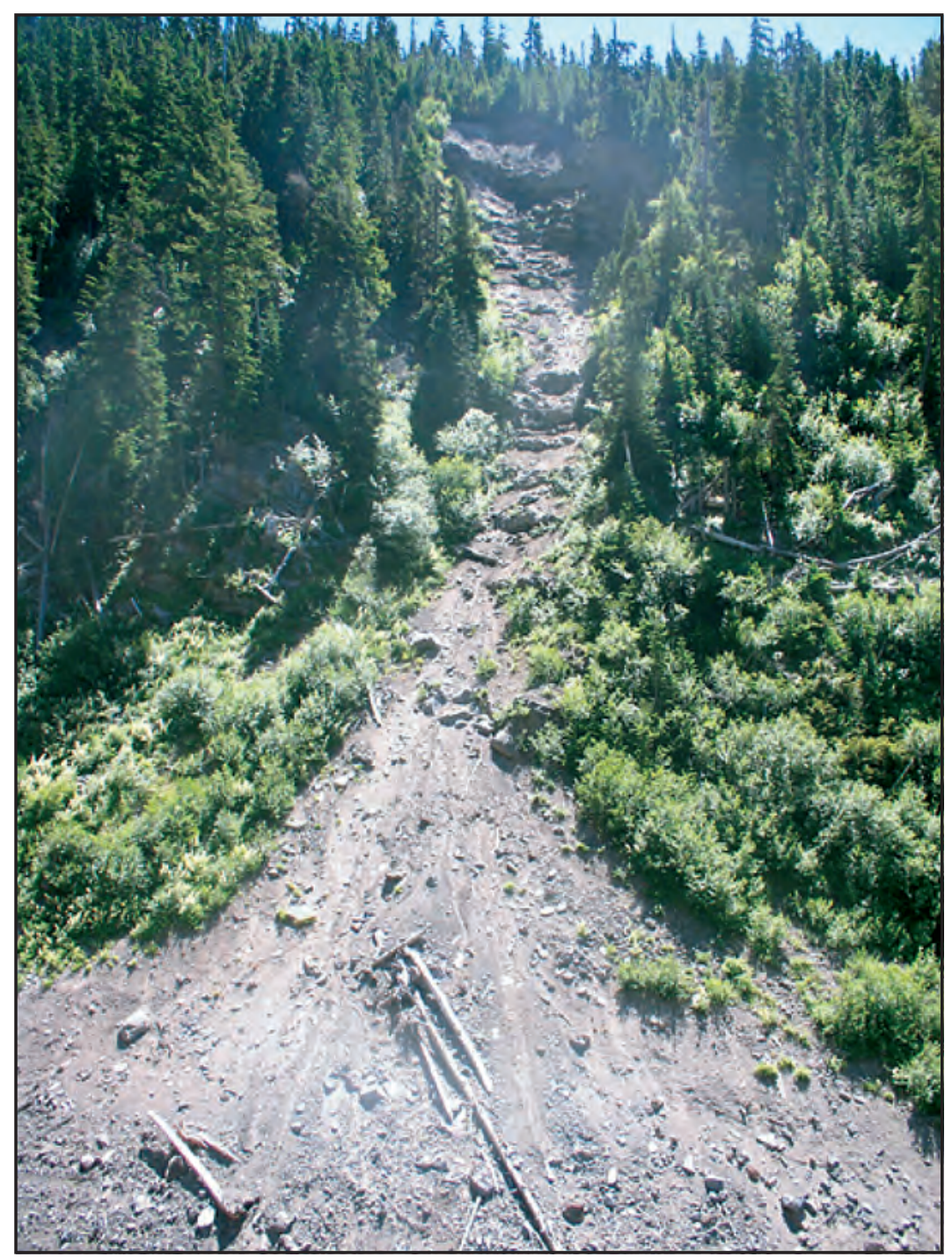

Figure 29. Landslide in Mt. Jefferson Wilderness Area in the upper North Santiam River basin, Oregon. (Photograph by U.S. Geological Survey, taken in 2005). 
January 28-30, 2004-Little North Santiam River

\section{Conditions}

For over a week, beginning on January 23, a series of storms passed over the North Santiam River basin, depositing more than 10 in. of rain (Oregon Climate Service, 2006). During January 28-30, more than 5 in. of rain fell, raising streamflow to $4,960 \mathrm{ft}^{3} / \mathrm{s}$ at the North Santiam monitoring station, 4,690 $\mathrm{ft}^{3} / \mathrm{s}$ at Breitenbush, 2,350 $\mathrm{ft}^{3} / \mathrm{s}$ at French, and
$1,090 \mathrm{ft}^{3} / \mathrm{s}$ at Blowout. The highest flows were recorded at the Little North monitoring station at $12,700 \mathrm{ft}^{3} / \mathrm{s}$. The continuous rainfall mobilized sediment, increasing turbidity to $25 \mathrm{FNU}$ at the North Santiam monitoring station, 71 FNU at Breitenbush, 27 FNU at Blowout, and 251 FNU at Little North (fig. 30). Along the lower mainstem North Santiam River, turbidity reached as high as 290 and 154 FNU at Mehama and Geren Island, respectively. High turbidity during this storm prompted the closure of the water-treatment facility (Hank Wujcik, City of Salem Public Works Department, written commun., 2005). Values were missing at the North Santiam River at Niagara station because the water-quality monitor was malfunctioning.

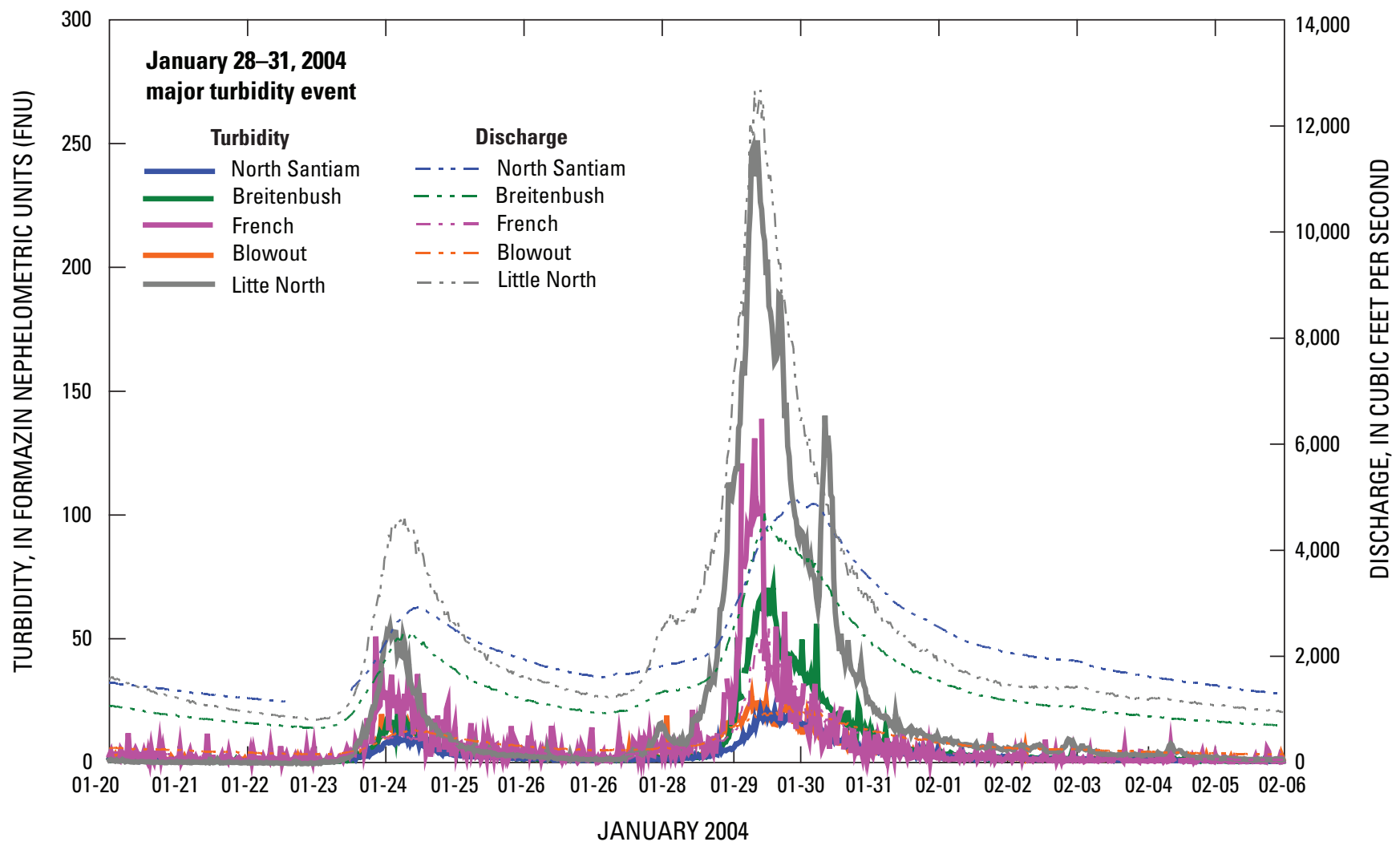

Figure 30. Turbidity and discharge at five unregulated stream monitoring stations for the January 28-30, 2004, major turbidity event in the North Santiam River basin, Oregon. 
Suspended-Sediment Loads and Clay-Water

Volumes and Yields

During the 3-day storm period, the Little North Santiam River carried 11,394 tons of suspended-sediment, a yield of 102 tons $/ \mathrm{mi}^{2}$ (table 10). Even though turbidity values were relatively low compared to those measured during previous major turbidity events, the long duration and high streamflow made this a major event. This was the third highest event yield for the Little North Santiam subbasin during the study duration and also was the largest Little North Santiam high-turbidity event as calculated using instream turbidity rather than using streamflow as a surrogate for turbidity, as with previous Little North Santiam River estimates. For comparison, using streamflow to estimate loads would have resulted in an estimate of 7,060 tons, 40 percent less than what was predicted using instream turbidity. That would decrease the percentage of annual load for this event from 64 to 39 percent. Clay-water volumes would have been underestimated as well. For example, there would be 2,384 Mgal less if discharge were used rather than instream turbidity. Therefore, previous estimates for 1998 and 1999 could have been much greater for the Little North Santiam River had monitoring stations been in place.

Table 10. Suspended-sediment load and yield, and clay-water volume and yield for the January 28-30, 2004, major turbidity event in the North Santiam River basin, Oregon.

[Abbreviations: ton $/ \mathrm{mi}^{2}$, ton per square mile; Mgal, million gallons; $\mathrm{Mgal} / \mathrm{mi}^{2}$, million gallons per square mile]

\begin{tabular}{|c|c|c|c|c|c|c|}
\hline \multirow{2}{*}{$\begin{array}{c}\text { Station } \\
\text { name }\end{array}$} & \multicolumn{3}{|c|}{ Suspended sediment } & \multicolumn{3}{|c|}{ Clay-water } \\
\hline & $\begin{array}{l}\text { Load } \\
\text { (ton) }\end{array}$ & $\begin{array}{l}\text { Percentage of } \\
\text { annual load }\end{array}$ & $\begin{array}{c}\text { Yield } \\
\text { (ton/mi²) }\end{array}$ & $\begin{array}{l}\text { Volume } \\
\text { (Mgal) }\end{array}$ & $\begin{array}{l}\text { Percentage of } \\
\text { annual volume }\end{array}$ & $\begin{array}{c}\text { Yield } \\
\left({\left.\mathrm{Mgal} / \mathrm{mi}^{2}\right)}^{2}\right.\end{array}$ \\
\hline \multicolumn{7}{|c|}{ Upper basin stations } \\
\hline North Santiam & 633 & 9 & 3 & 0 & 0 & 0 \\
\hline Breitenbush & 1,776 & 39 & 16 & 0 & 0 & 0 \\
\hline French & 374 & 52 & 37 & 0 & 0 & 0 \\
\hline Blowout & 166 & 16 & 6 & 0 & 0 & 0 \\
\hline \multicolumn{7}{|c|}{ Lower basin station } \\
\hline Little North & 11,394 & 64 & 102 & 8,157 & 78 & 73 \\
\hline
\end{tabular}




\section{Sources of Turbidity}

Field investigations pointed to a landslide in the Evans Creek watershed, near the community of Elkhorn, as the source of turbidity to the Little North Santiam River during this event (fig. 31). The landslide on Evans Creek covers more than 20 acres on the western slope of Evans Mountain (fig. 32) and displays all the characteristics of a large, natural, complex landslide: multiple scarps, debris flow channels, and transverse cracks (fig. 33). Its earliest documentation dates to the late 1970s (Hank Wujcik, City of Salem Public Works Department, written commun., 2005), although storms from the flood of 1964 probably had mobilized this area earlier. The failure of Evans Mountain Road occurred during the flood of 1996, with additional movement in 1997 (Jerry Pierce, Upward Bound Camp, oral commun., 2006). Because the landslide intersects the creek, material is constantly being eroded whenever higher flows occur. In addition, erosion of exposed surfaces of the landslide transports turbid water into the creek. Because of the proximity of the Little North Santiam River to the City of Salem water-treatment facility (about 10 mi upstream), turbid water emanating from the subbasin is a major concern.

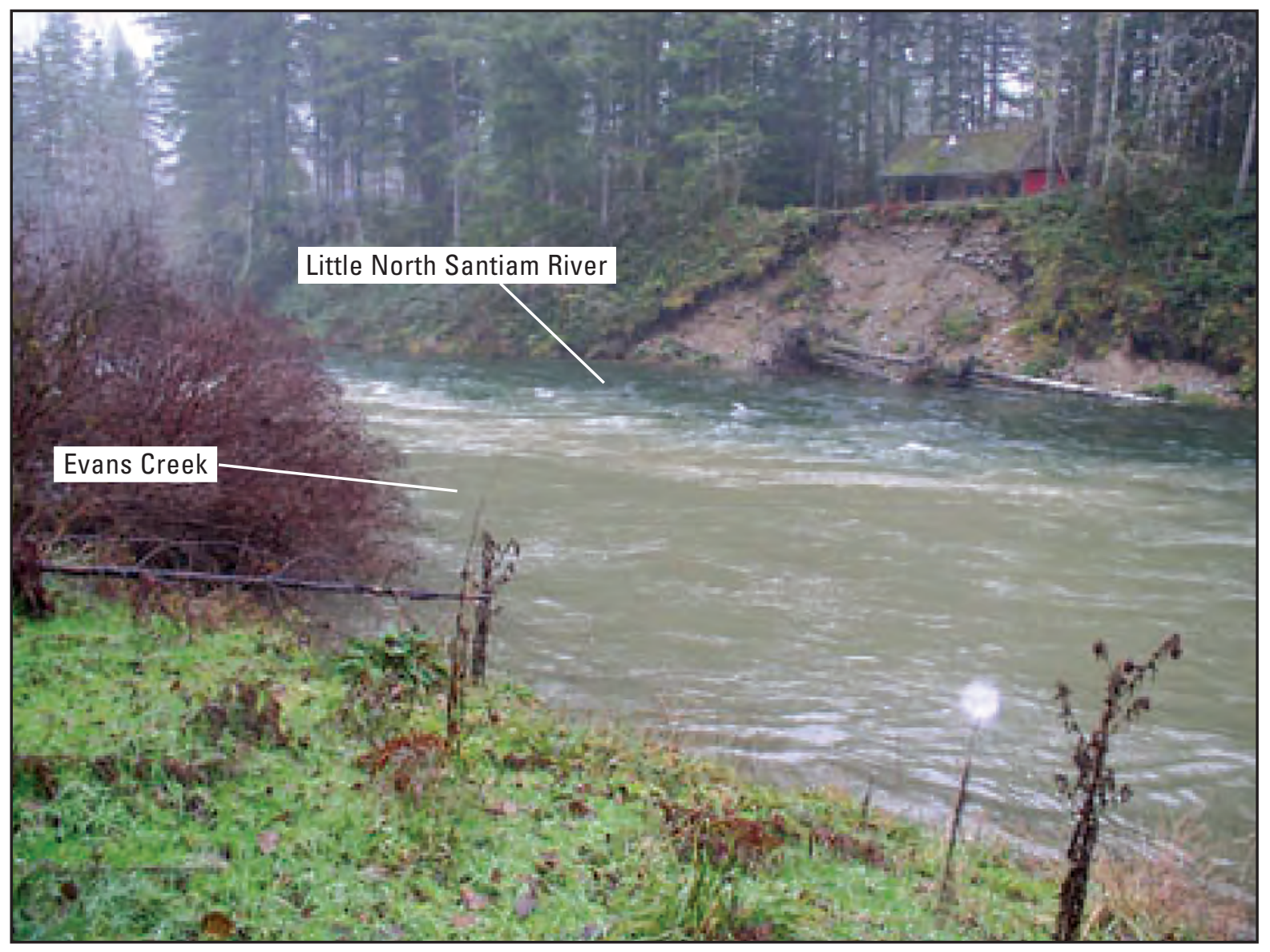

Figure 31. Turbid water flowing from Evans Creek into the Little North Santiam River, Oregon, in January 2004. (Photograph by U.S. Geological Survey, taken in 2004). 


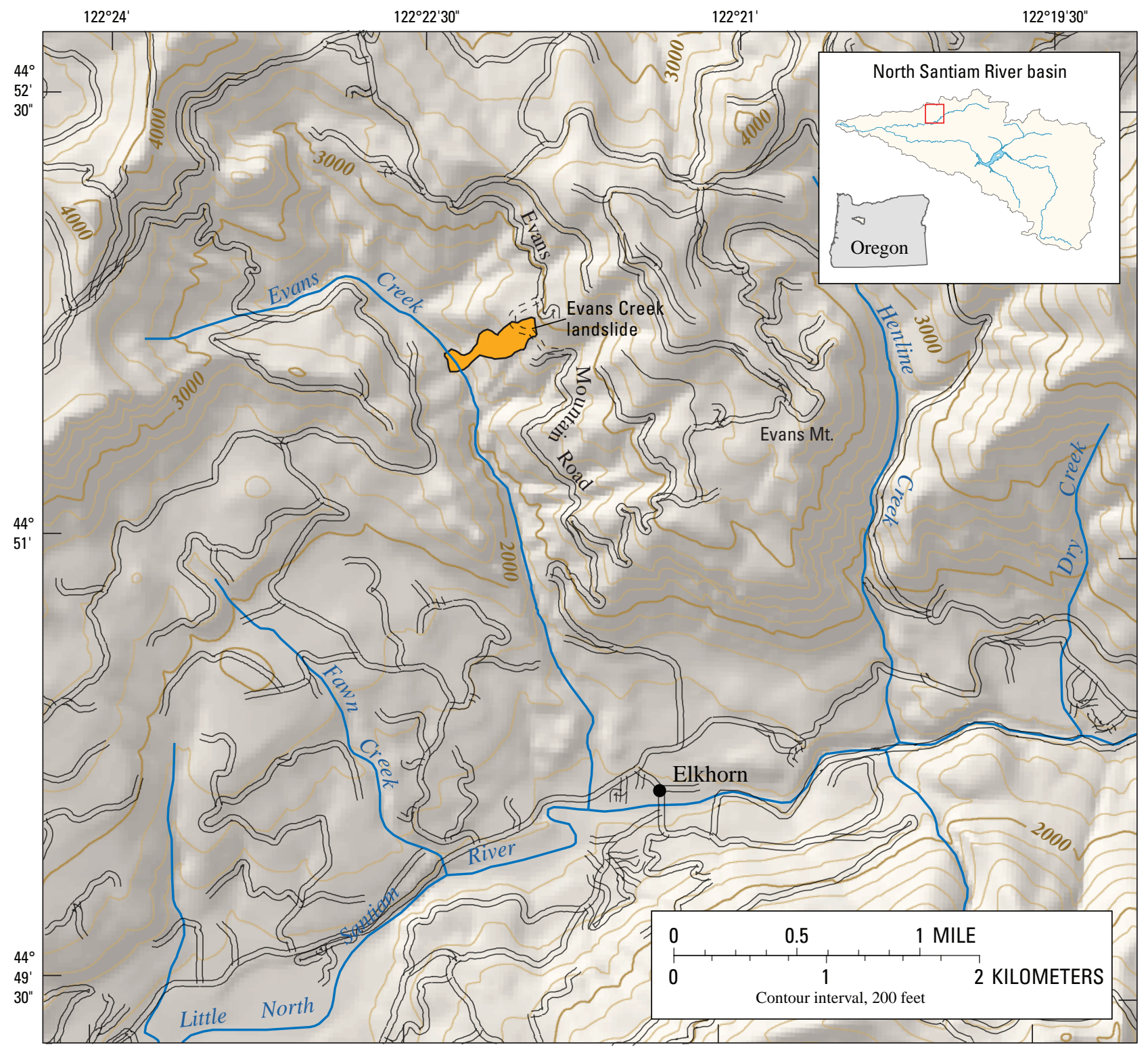

Base modified from USGS digital data, various scales, variously dated

Universe Transverse Mercator projection

Zone 10, North American Datum of 1927

Figure 32. Location of the Evans Creek landslide in the Little North Santiam River subbasin of the North Santiam River basin, Oregon. 


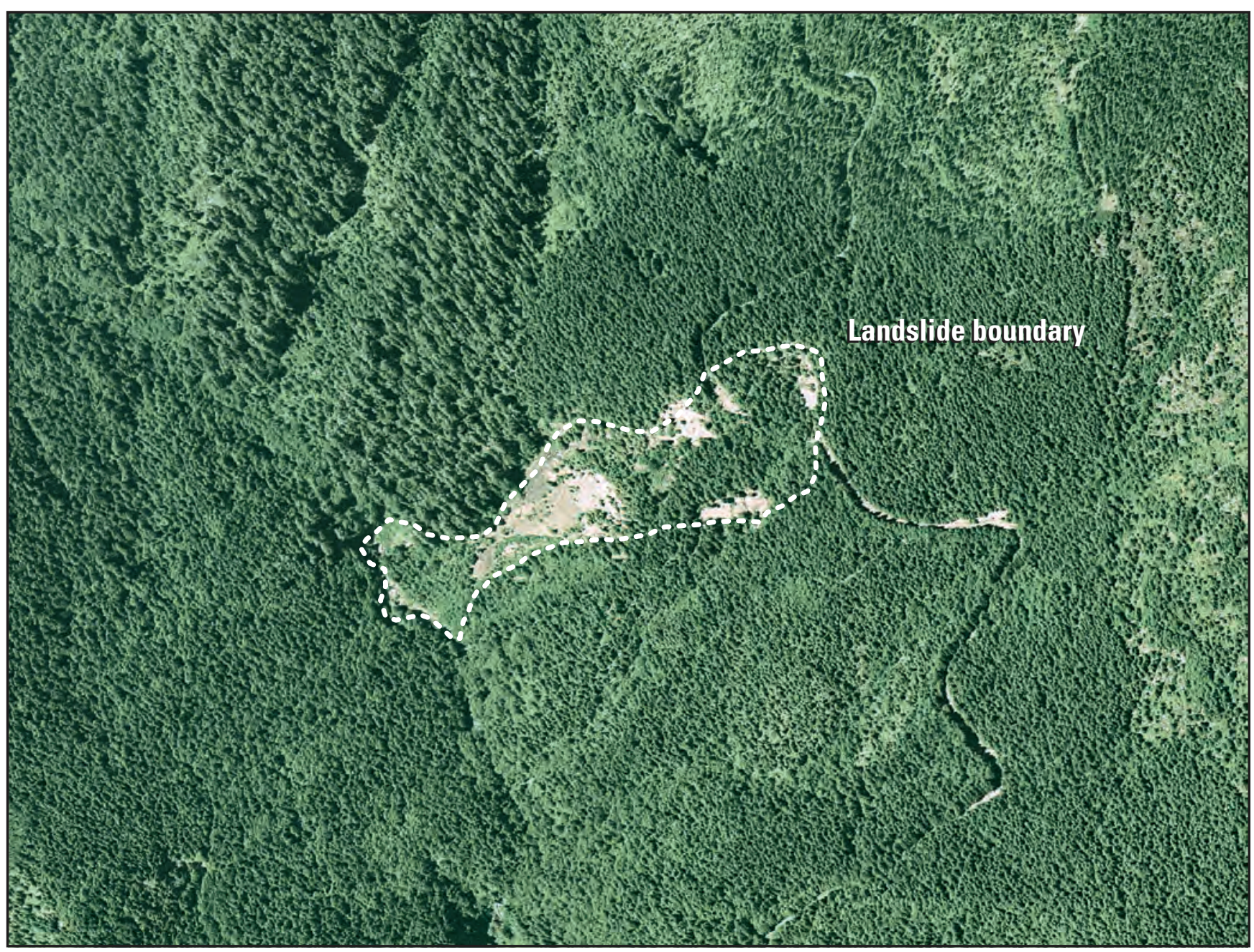

Figure 33. Evans Creek landslide in the Little North Santiam River subbasin of the North Santiam River basin, Oregon. (Aerial photograph by Oregon Department of Forestry, taken in 2000). 


\section{Follow-Up Investigations}

To assess sediment input from Evans Creek, temporary water-quality monitors were installed on Evans Creek and on the Little North Santiam River at Elkhorn, just upstream from Evans Creek. Turbidity data from these monitors confirms earlier assumptions that Evans Creek flows often are considerably more turbid than those of the mainstem of the Little North Santiam River during runoff events. For example, in late December 2005, turbidity in Evans Creek was, on average, more than 30 times greater than that in the Little North Santiam River at Elkhorn, yet only 3.5 times greater than turbidity measured downstream at the Little North monitoring station (fig. 34). Although Evans Creek may not be the only sediment source, it appears to be one of the uppermost subbasin sources. Further investigation into other potential source areas between Evans Creek and the permanent water-quality monitor at the mouth of the Little North Santiam River is currently underway.

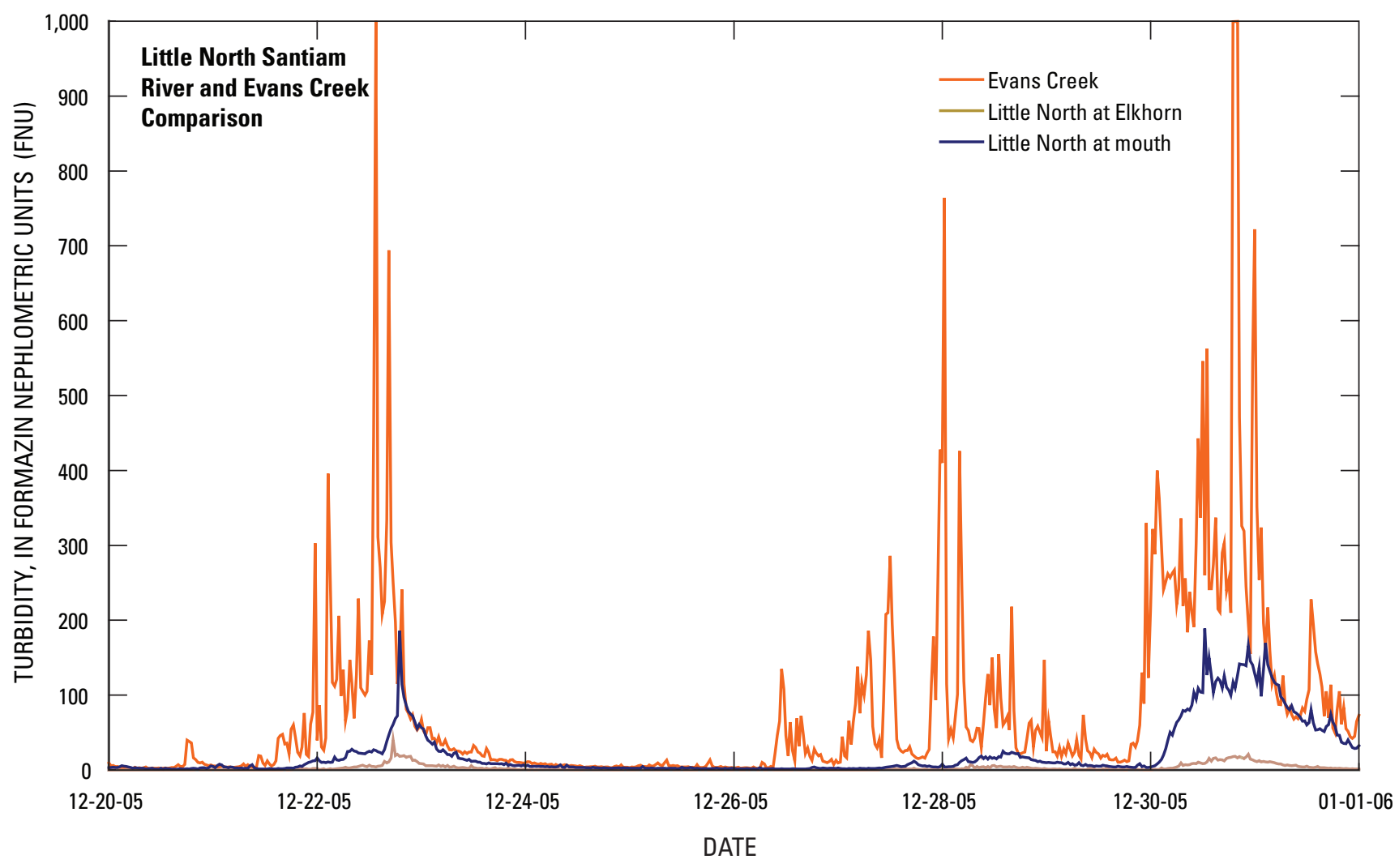

Figure 34. Turbidity values at three locations within the Little North Santiam River subbasin, Oregon, December 2005. 


\section{Sedimentation Processes}

\section{Precipitation-Driven Landsliding}

Analysis of the major turbidity events in the North Santiam River basin revealed a few general trends. Most major turbidity events were initiated by rainfall. The largest turbidity events also often incorporated multiple sediment sources; however, in each case, at least one discrete contributing source area existed. In most cases, landslides (as earthflows or debris flows) were the most common sediment sources. In general, landslides developed where rainfall saturated heavily reworked and weak subsurface rocks or sediments, such that high pore-water pressures exceeded the residual strength of the saturated material (Dikau and others, 1996). Other factors that also may have caused landsliding include geologic setting, slope characteristics, hydrologic properties of the soils, subsurface flow, characteristics of the surface vegetation, and land-management practices such as timber harvesting, road construction, and residential development (Sidle and others, 1986).

\section{Snowmelt-Driven Glacial Outwash}

The catalyst for two of the major turbidity events was increased snowmelt. During warm conditions (as in October 2000 and 2003), High Cascade snowpack melted, either releasing stored material or eroding away loose, unconsolidated soils. In addition, sometimes as part of the autumn melt, water and sediment may have been released from receding glaciers. Although not as severe as glacial outburst floods that can occur in the Cascades (Walder and Driedger, 1994; O'Connor and others, 2001), the increased runoff would erode existing High Cascade landslides. The seasonality of the glacial events separated them from the other sediment sources in the North Santiam River basin that mobilized during rainy winters. Turbidity signatures from the glacial or snowmeltdriven events were unique because they were associated with minor or no increase in discharge. This likely was a result of the low streamflow from Milk Creek as compared to that of the upper North Santiam River. Determining the exact contributing area in the Mount Jefferson Wilderness Area was problematic because the terrain was remote and inaccessible. Rapidly changing environmental conditions also limited remote sensing opportunities.

\section{Anthropogenic Influences}

Besides natural characteristics, anthropogenic factors also influenced sediment production in the basin. For example, road construction increased surface runoff, and in at least one case, promoted landsliding (see section, "December 17-19, 2001-Blowout Creek"). In general, road construction changes slope stability and hydrologic drainage by adding weight to the slope with embankment fill, increasing steepness of the slope on the cut and fill surfaces, reducing the support for a cutslope, and rerouting and concentrating surface water (Sidle and others, 1986; Montgomery, 1994; U.S. Forest Service, 2001). As with other types of mass wasting, sedimentation resulting from road-related landsliding most often occurred during periods of intense or prolonged rainfall (Wemple and others, 2001).

\section{Land-Management Concerns}

\section{Feature Types of Interest}

During the study, earthflows and debris flows were the two feature types that routinely supplied large amounts of material to streams.

\section{Earthflows}

Earthflows are fine grained and clay rich, with 7090 percent of the clay fraction composed of smectite clays (Hulse and others, 2002). Smectite clays have the finest particle-size distribution of naturally occurring clay minerals (less than $0.05 \mu \mathrm{m}$ ) and are a major component of persistent turbidity (Bates and others, 1998; Hulse and others, 2002). Originating in unstable soils generated from eroded volcanic rocks, such as those in the Western Cascades and Foothills, smectite clays are abundant in the upper North Santiam River basin. Smectite clays and other amorphous material, such as kaolinite, commonly calve off or are eroded away from earthflows, especially during high flows. Although the sediment loads may not be large, they can produce persistent high turbidity because the clay particles remain in suspension for prolonged periods. 


\section{Major Turbidity Events in the North Santiam River Basin, Oregon, Water Years 1999-2004}

U.S. Forest Service researchers have mapped 274 active earthflows in the Willamette National Forest area of the North Santiam River basin (Shank, 2004). Of these active earthflows, 252 were nonnested - not contained in another earthflow_and account for 1.4 percent $\left(6.6 \mathrm{mi}^{2}\right)$ of forest land. Stabilized earthflows, estimated to be hundreds to thousands of years old, have been mapped as well, and account for an additional 7.3 percent $\left(35.1 \mathrm{mi}^{2}\right)$. Thus, nearly 10 percent of the forest has been affected by earthflows during the last few thousand years. Of the 252 nonnested active earthflows, 86 intersect streams and are considered active sediment-producing sources. The $13 \mathrm{mi}$ of stream adjacent to these sediment-producing earthflows amount to 2.3 percent of the total drainage density of the Willamette National Forest within the North Santiam River basin.

\section{Debris Flows}

In addition to earthflows, debris flows also are known sediment sources. For example, following the flood of 1996, the Oregon Department of Geology and Mineral Industries mapped the location of 568 "rapidly moving landslides," or debris flows, which occurred in Marion and Linn Counties (Hofmeister, 2000; Hofmeister and others, 2002). Of those debris flows, 216 originated in the North Santiam River basin, equating to a density of about 1 debris flow per every $3 \mathrm{mi}^{2}$. The steep slopes and accumulated sediments of the Western Cascades (see section, "Geology") further aid in the abundance and frequency of debris flows. Since the flood of 1996, several debris flows have occurred in the basin. For example, during the same January 2003 storm that mobilized a debris flow in French Creek (see section, "January 30February 1,2003-French Creek," a second debris flow mobilized in the Blowout Creek subbasin. The debris flow uprooted vegetation and carried it downslope, eventually blocking, and then expelling, a culvert beneath Forest Road 10 (fig. 35). This debris flow and road-failure sequence was converse to the road failure near Ivy Creek (see section, "December 17-19, 2001-Blowout Creek"), as the debris caused the road damage, rather than originating from road material. No sediment values or turbidity measurements exist for this failure because it occurred downstream of the Blowout monitoring station.

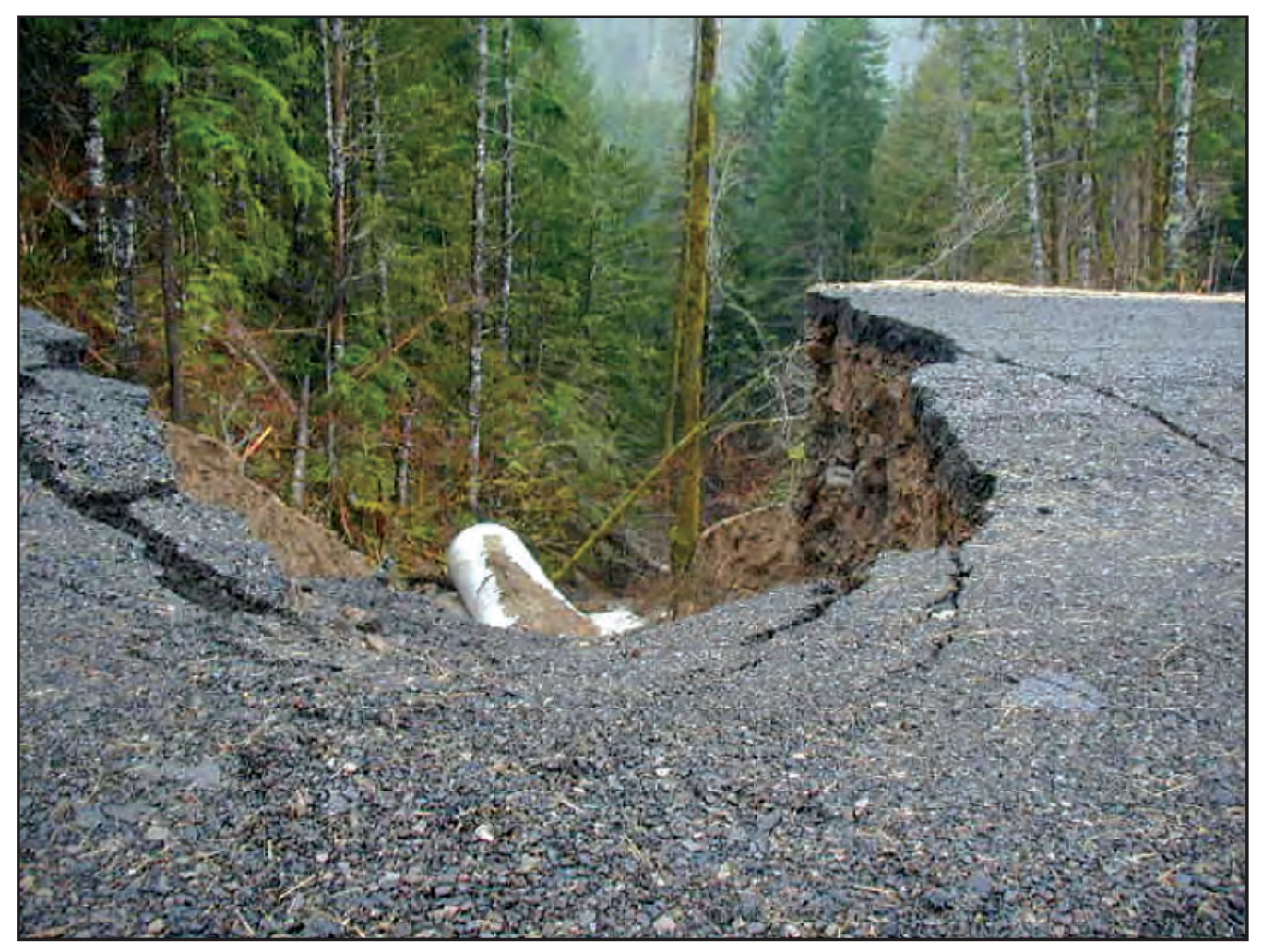

Figure 35. Culvert failure on Forest Road 10 in the Blowout Creek subbasin of the North Santiam River basin, Oregon. (Photograph by U.S. Geological Survey, taken in 2003). 


\section{Source Areas of Interest}

Each subbasin in the North Santiam River basin has source areas that contribute to turbidity; however, the two drainage basins of greatest interest are those of the Little North Santiam River in the lower basin and Blowout Creek in the upper basin, upstream of Detroit Dam and reservoir. Both subbasins produce, on average, the first- and second-largest clay-water volume in the North Santiam River basin (table 11) and therefore greatly affect the water quality in the basin.

The most immediate concern for drinking-water quality is turbid water from the Little North Santiam River. Not only does the Little North Santiam River transport the greatest amount of clay-water, but the turbid water also greatly affects water treatment because the unregulated streamflow enters only a few miles upstream of the treatment facility. Even though the highest recorded turbidity values from the Little North Santiam River have been in the low hundreds (unlike those in the upper basin, which can reach into the thousands), the short travel time can quickly overwhelm the facility. Therefore, scientists are closely examining known sources in the subbasin, such as the Evans Creek landslide and the numerous road failures along North Fork Road.

Blowout Creek is a concern because it transports the second-largest amount of clay-water in the North Santiam River basin. This is in large part because the subbasin has the largest density of mapped active and stabilized earthflows, with $1.8 \mathrm{mi}^{2}$ of actively moving terrain $(7$ percent of the subbasin) and $9.9 \mathrm{mi}^{2}$ of stabilized earthflows (38 percent of the subbasin; Shank, 2004). Even though Detroit Lake normally serves as a settling basin for most suspended clay from upstream drainage basins, such as Blowout Creek, and prevents its passage to the lower North Santiam River mainstem, during basinwide very high-streamflow events like that of 1996, a large volume of turbid water from upstream can pass through Detroit Dam and affect the operation of the City of Salem water-treatment facility (Hulse and others, 2002).

\section{Future Research}

U.S. Forest Service observations suggest that earthflows are the predominant source for persistent turbidity in the North Santiam River basin (Douglas Shank, U.S. Forest Service, oral commun., 2004; David Klug, U.S. Forest Service, oral commun., 2005). Earthflow movement and clay-rich sediment contribution to streams also have been documented in previous Western Cascades studies (Swanson and Swanston, 1977; Bates and others, 1998; Pearch, 2000; Hulse and others, 2002). To build on this research, it would be beneficial to study earthflow movement and sedimentation in the North Santiam River basin. Because geomorphologic and meteorological conditions can differ greatly among basins in the Western Cascades, monitoring turbidity is important for understanding the influence of these factors on persistent turbidity. Additional turbidity monitoring downstream of suspected sediment sources may support inferences drawn to date from existing data. The additional data also will help identify currently unknown sources of sediment and persistent turbidity in the North Santiam River basin. Such information will help resource managers determine whether earthflows are the primary contributor of persistent turbidity or if other landscape features, changes, and uses are the cause of clay loads to the North Santiam River. 


\section{Summary}

From October 1998 to September 2004 (water years 1999-2004), turbidity exceeded 250 Formazin Nephelometric Units on several occasions in streams in the North Santiam River basin in Oregon. This study, done in cooperation with the City of Salem, Oregon, linked eight of these periods of high turbidity to likely source areas, defining them as major turbidity events. For each of these major turbidity events, the study report describes the conditions, such as turbidity and streamflow; calculations, such as suspended-sediment load and clay-water volume; likely source areas, such as landslides or glacial outwash; and any follow-up investigations.

Data from each major turbidity event illustrated that different processes drove sediment loading at different times. The most common catalyst was precipitation, as six of the eight major turbidity events corresponded to a particular storm system. The remaining two events were caused by snowmelt-driven erosion from sediments originating in the Mount Jefferson Wilderness Area. Each subbasin within the North Santiam River basin was capable of producing high turbidity, as demonstrated by the diversity of events in this report; although, generally, the Little North Santiam River and Blowout Creek subbasins produced larger volumes of sediment and clay-water during precipitation events. The largest major turbidity event in this study was produced by the Breitenbush River subbasin in November 1999. Large suspended-sediment loads commonly were caused by more than one source in a subbasin, such as multiple landslides or earthflows. In most of the multiple-source events, it was impossible to determine every source, although at least one likely source always was identified. For some events, such as the road failure near Ivy Creek, field observations were able to directly link discrete source areas with suspended-sediment load and clay-water volume calculations.

\section{Acknowledgments}

The authors thank the City of Salem, Oregon, for providing support and guidance. Special thanks to Hank Wujcik of the City of Salem, and David Klug and Douglas Shank of the U.S. Forest Service for their field assistance and for supplying helpful data; this study could not have been done without them. We would like to give additional thanks to Rosana Costello of the U.S. Forest Service and Jodi Kroon of the Oregon Department of Forestry for supplying GIS data and aerial photos. Others within the U.S. Geological Survey who assisted in the collection of samples and who contributed their considerable technical skills that we would like to thank include David Piatt, Joseph Rinella, Stewart Rounds, and John Williams. Additional thanks to Jackie Olson for her assistance in illustration design and graphics, and to James O'Connor and Casey Lee for reviewing this document.

\section{References Cited}

Anderson, C.W., 2005, Turbidity (version 2.1): Techniques of Water-Resources Investigations of the U.S. Geological Survey, book 9, chap. A6, sec. 6.7, accessed February 2007, at http://pubs.water.usgs.gov/twri9A6/

Bates, Deigh, Willis, Katherine, Swanson, F.J., Glassman, J.R., Halemeier, David, and Wujcik, Hank, 1998, North Santiam River turbidity study, 1996-1997: Subbasin Management Council Networker, Fall 1998, p. 1-16.

Bragg, H.M., Sobieszczyk, S., Uhrich, M.A., and Piatt, D.R., 2007, Suspended-sediment loads and yields in the North Santiam River basin, Oregon, 1999-2004: U.S. Geological Survey Scientific Investigations Report 2007-5187, 26 p.

Cooper, R.M., 2005, Estimation of peak discharges for rural, unregulated streams in western Oregon: U.S. Geological Survey Scientific Investigations Report 2005-5116, 134 p.

Cruden, D.M., and Varnes, D.J., 1996, Landslide types and processes, in Turner, A.K., and Schuster, R.L., eds., Landslides: Investigations and mitigation: Transportation Research Board, Special Report 247, chap. 3, p. 36-75.

Dikau, Richard, Brunsden, Denys, Schrott Lothar, and Ibsen, Maïa-Laura, eds., 1996, Landslide recognition: New York, John Wiley and Sons, $251 \mathrm{p}$.

Edwards, T.K., and Glysson, G.D., 1999, Field methods for measurement of fluvial sediment: Techniques of WaterResources Investigations of the U.S. Geological Survey, book 3, chap. 22, 89 p.

Hofmeister, R.J., 2000, Slope failures in Oregon, GIS inventory for three 1996/97 storm events: Oregon Department of Geology and Mineral Industries Special Paper 34, 20 p., 1 compact disc.

Hofmeister, R.J., Miller, D.J., Mills, K.A., Hinkle, J.C., and Beier, A.E., 2002, Hazard map of potential rapidly moving landslides in western Oregon: Oregon Department of Geology and Mineral Industries Interpretive Map Series IMS-22, 49 p.

Hulse, David, Grant, G.E., Niemi, Ernie, Branscomb, Allan, Diethelm, David, Ulrich, Ryan, and Whitelaw, Ed, 2002, Muddy waters-How floods clarify evolving relationships among landscape processes and resource management decision-making in municipal subbasins: Eugene, Oreg., University of Oregon, Department of Landscape Architecture, EPA/NSF Final Project Report GAD\# R82582232, 32 p. 
Montgomery, D.R., 1994, Road surface drainage, channel initiation, and slope instability: Water Resources Research, v. 30 , no. 6 , p. $1925-1932$.

O`Connor, J.E., Hardison, J.H., and Costa, J.E., 2001, Debris flows from failures of Neoglacial-age moraine dams in the Three Sisters and Mount Jefferson Wilderness Areas, Oregon: U.S. Geological Survey Professional Paper 1606, 93 p., 2 pls.

Oregon Climate Service, 2006, Climate data: Zone 2/ Precipitation: Daily/Stayton and Zone 4/Precipitation: Daily/Detroit Dam-Climate data archives: accessed December 2006, at http://www.ocs.oregonstate.edu/index. $\underline{\mathrm{html}}$

Pearch, J.M., 2000, Relationships between landscape stability, clay mineralogy, and stream turbidity in the South Santiam Watershed, Western Cascades, Oregon: Corvallis, Oreg., Oregon State University, Master of Science Thesis, 199 p.

Porterfield, George, 1972, Computation of fluvial-sediment discharge: Techniques of Water-Resources Investigations of the U.S. Geological Survey, book 3, chap. C3, 66 p.

Rantz, S.E., 1982, Measurement and computation of streamflow: U.S. Geological Survey Water-Supply Paper 2175, 2 vols., $631 \mathrm{p}$.

Shank, Douglas, 2004, Doug's soil resource inventory: U.S. Forest Service, Willamette National Forest, Sweet Home Ranger District, CD ROM.

Sherrod, D.R., Ingebritsen, S.E., Curless, J.M., Keith, T.E., Diaz, N.M., DeRoo, T.G., and Hurlocker, S.L., 1996, Water, rocks, and woods-A field excursion to examine the geology, hydrology, and geothermal resources in the Clackamas, North Santiam, and McKenzie River drainages, Cascade Range, Oregon: Oregon Geology, v. 58, no. 5, p. 103-124.

Sherrod, D.R., and Smith, J.G., 2000, Geologic map of upper Eocene to Holocene volcanic and related rocks of the Cascade Range, Oregon: U.S. Geological Survey Geologic Investigations Series I-2569 [and associated digital dataset].

Sidle, R.C., Pearce, A.J., and O'Loughlin, C.L., 1986, Hillslope stability and land use: Washington, D.C., American Geophysical Union, Water Resources Monograph $11,140 \mathrm{p}$.

Swanson, F.J., and Swanston, D.N., 1977, Complex massmovement terrains in the western Cascade Range, Oregon: Geological Society of America, Reviews in Engineering Geology, v. 3, p. 113-124.
Uhrich, M.A., and Bragg, H.M., 2003, Monitoring instream turbidity to estimate continuous suspended-sediment loads and clay-water volumes in the upper North Santiam River Basin, Oregon, 1998-2000: U.S. Geological Survey WaterResources Investigation Report 03-4098, 43 p.

U.S. Environmental Protection Agency, 2002, Drinking Water Contaminants: accessed August 2006, at http://www.epa. gov/safewater/mcl.html

U.S. Forest Service, 1992, Soil Resource Inventory: Willamette National Forest Supervisor's Office Geographic Information Systems Data Dictionary, accessed April 2007, at http://www.fs.fed.us/r6/willamette/manage/gis/sri.htm

U.S. Forest Service, 1998, Willamette National Forest retaining wall inventory-Data dictionary [and associated digital dataset]: U.S. Forest Service, Willamette National Forest, December 1998, 4 p.

U.S. Forest Service, 1999a, Willamette National Forest emergency relief for federally owned roads (ERFO) sites from the 1996 and 1997 flood events—Data dictionary [and associated digital dataset]: U.S. Forest Service, Willamette National Forest, February 1999, 13 p.

U.S. Forest Service, 1999b, Willamette National Forest: Forest plan monitoring sites of mass movement-Data dictionary [and associated digital dataset]: U.S. Forest Service, Willamette National Forest, June 1999, 4 p.

U.S. Forest Service, 2001, Forest roads-A synthesis of scientific information, in Gucinski, Hermann, Brookes, M.H., Furniss, M.J., and Ziemer, R.R., eds.: U.S. Forest Service, Pacific Northwest Research Station, General Technical Report PNW-GTR-509, p. 12-21.

U.S. Forest Service [2001], Decision memo-East Hum unit 5 stand establishment and slide risk reduction project: U.S. Forest Service, Willamette National Forest, Detroit Ranger District, $10 \mathrm{p}$.

U.S. General Accounting Office, 1998, Oregon watershedsMany activities contribute to increased turbidity during large storms: Washington D.C., Report to Congressional Requesters, GAO/RCED-98-220, 69 p.

U.S. Geological Survey, 2005, National Land Cover Database 2001 (NLCD 2001): accessed June 2006, at http://www. mrlc.gov/mrlc2k nlcd.asp 
Wagner, R.J., Boulger, R.W., Jr., Oblinger, C.J., and Smith, B.A., 2006, Guidelines and standard procedures for continuous water-quality monitors-Station operation, record computation, and data reporting: U.S. Geological Survey Techniques and Methods 1-D3, 51 p. plus attachments, accessed May 2007, at http://pubs.usgs.gov/ tm/2006/tm1D3/

Walder, J.S., and Driedger, C.L, 1994, Geomorphic change caused by outburst floods and debris flows at Mount Rainier, Washington, with emphasis on Tahoma Creek Valley: U.S. Geological Survey Water-Resources Investigations Report 93-4093, 93 p.

Walker, G.W., and MacLeod, N.S., 1991, Geologic map of Oregon: U.S. Geological Survey, 2 sheets, scale 1:500,000.
Wemple, B.C., Swanson, F.J., and Jones, J.A., 2001, Forest roads and geomorphic process interactions, Cascade Range, Oregon: Earth Science Processes and Landforms, v. 26, p. 191-204.

Wilde, F.D., Radtke, D.B., Gibs, Jacob, and Iwatsubo, R.T., eds., 1999, Collection of water samples-Techniques of Water-Resources Investigations of the U.S. Geological Survey, book 9, chap. A4, accessed February 2007, at http:// pubs.water.usgs.gov/twri9A4/

YSI Incorporated, 2007, List of products available from YSI Incorporated, accessed March 2007, at http://www.ysi. com/ysi/Products 
Manuscript approved for publication, August 2007

Prepared by the USGS Publishing Network,

Publishing Service Center, Tacoma, Washington

Bill Gibbs

Ellen Hardy

Bobbie Jo Richey

Linda Rogers

Sharon Wahlstrom

For more information concerning the research in this report, contact the Oregon Water Science Center Director,

U.S. Geological Survey, 92130 SW 5th Ave.

Portland, OR 97201

http://or.water.usgs.gov 


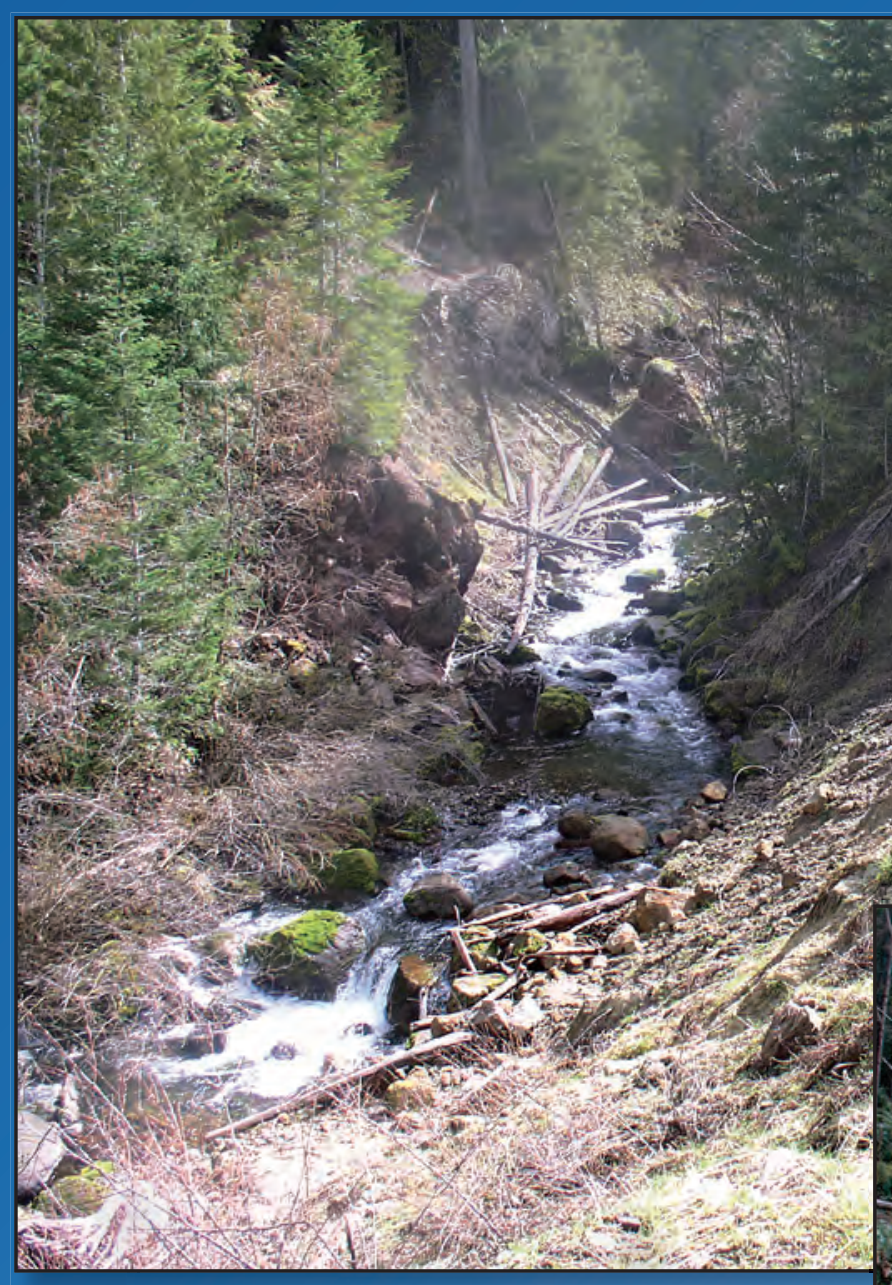

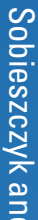

气

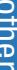

$\frac{3}{0}$

(20)

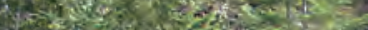

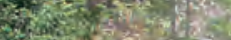

Qiphe

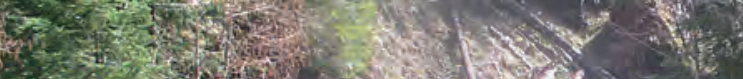

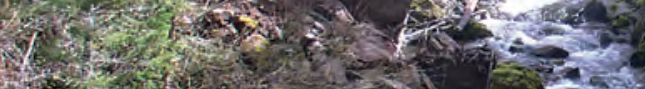

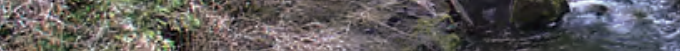
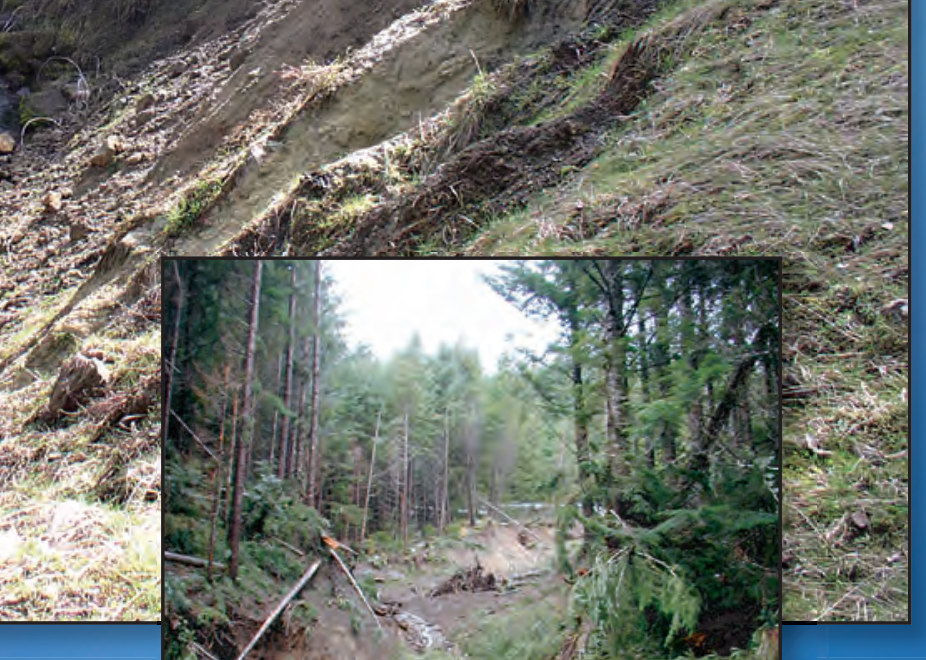

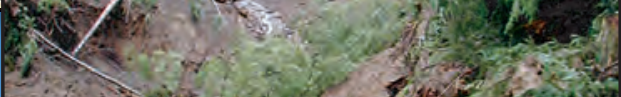

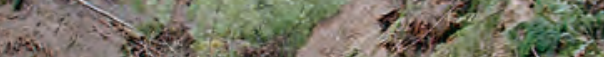

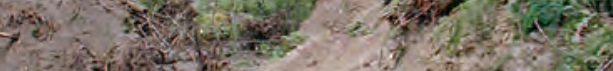

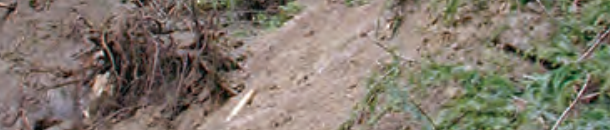

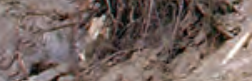

(1) +2010

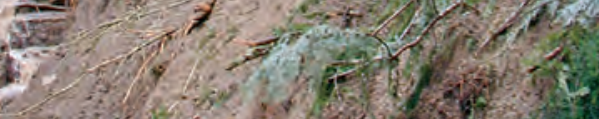

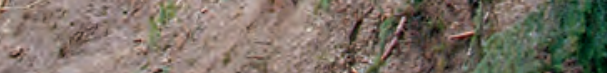

9 Printed on recycled paper 